\title{
Stratigraphy and Tectonic History of the Tucson Basin, Pima County, Arizona, Based on the Exxon State (32)-1 Well
}

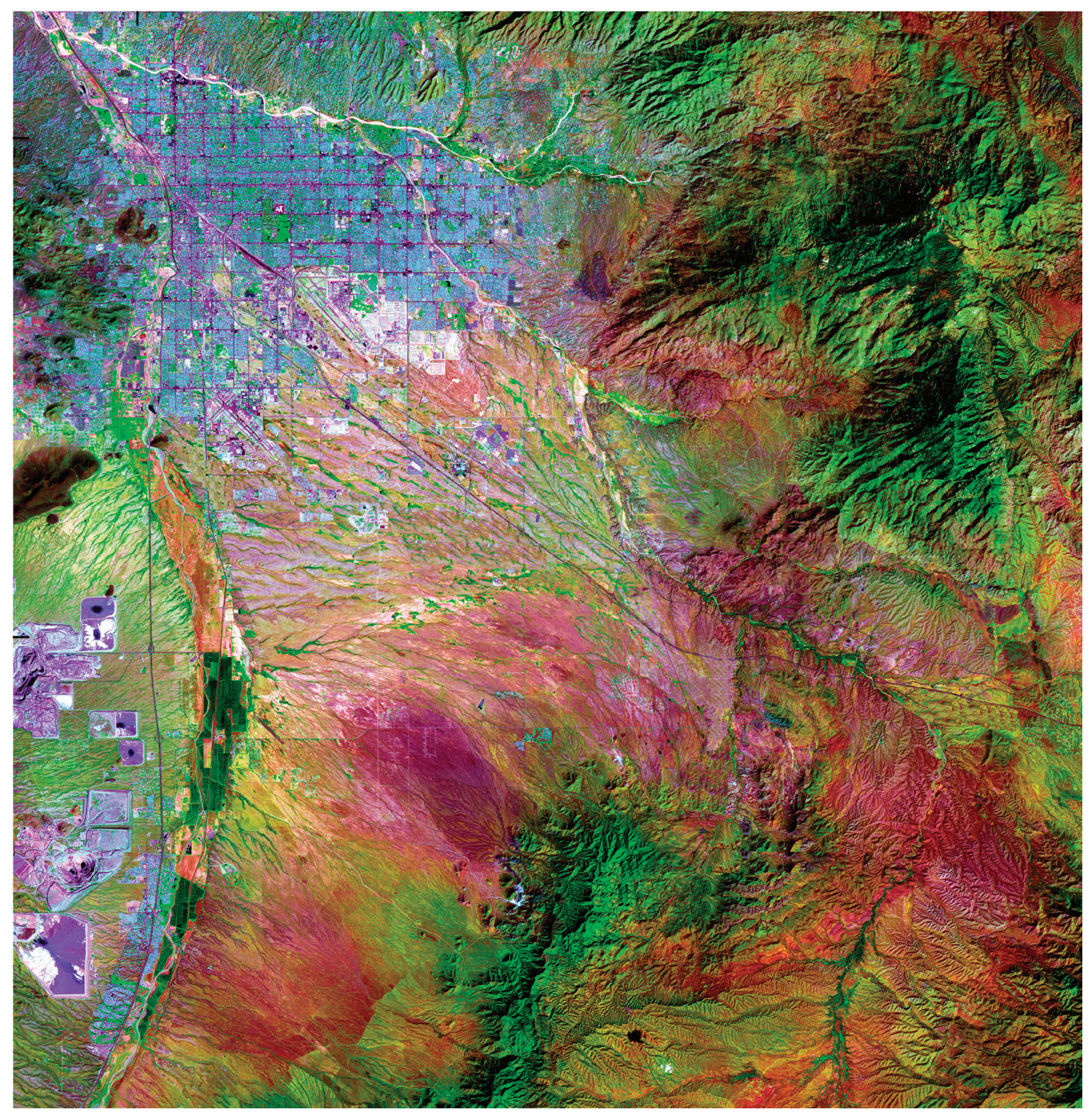

Scientific Investigations Report 2004-5076 


\section{Stratigraphy and Tectonic History of the Tucson Basin, Pima County, Arizona, Based on the Exxon State (32)-1 Well}

By Brenda B. Houser, Lisa Peters, Richard P. Esser, and Mark E. Gettings

A detailed stratigraphy is presented, based on well cuttings and geophysical logs, for the 3,658 $m$ of Upper Jurassic through upper Tertiary sedimentary and volcanic rocks overlying Precambrian(?) granitoid basement in the Tucson Basin. This is a revision of previous interpretations of Tucson Basin stratigraphy and is based in part on four new ${ }^{40} \mathrm{Ar} /{ }^{39} \mathrm{Ar}$ dates. The stratigraphic units are interpreted in terms of depositional environments and tectonic setting.

Scientific Investigations Report 2004-5076

U.S. Department of the Interior

U.S. Geological Survey 


\section{U.S. Department of the Interior}

Gale A. Norton, Secretary

\section{U.S. Geological Survey}

Charles G. Groat, Director

Version 1.0, 2005

This publication is available only online at: http://pubs.usgs.gov/sir/2004/5076/

Text edited by Peter H. Stauffer

Production and design by Stephen L. Scott

Manuscript approved for publication, April 30, 2004

Any use of trade, product, or firm names in this publication is for descriptive purposes only and does not imply

endorsement by the U.S. Government

FRONT COVER

Landsat satellite image of the Tucson Basin. See figure 2 (page 6) for explanation. 


\section{Contents}

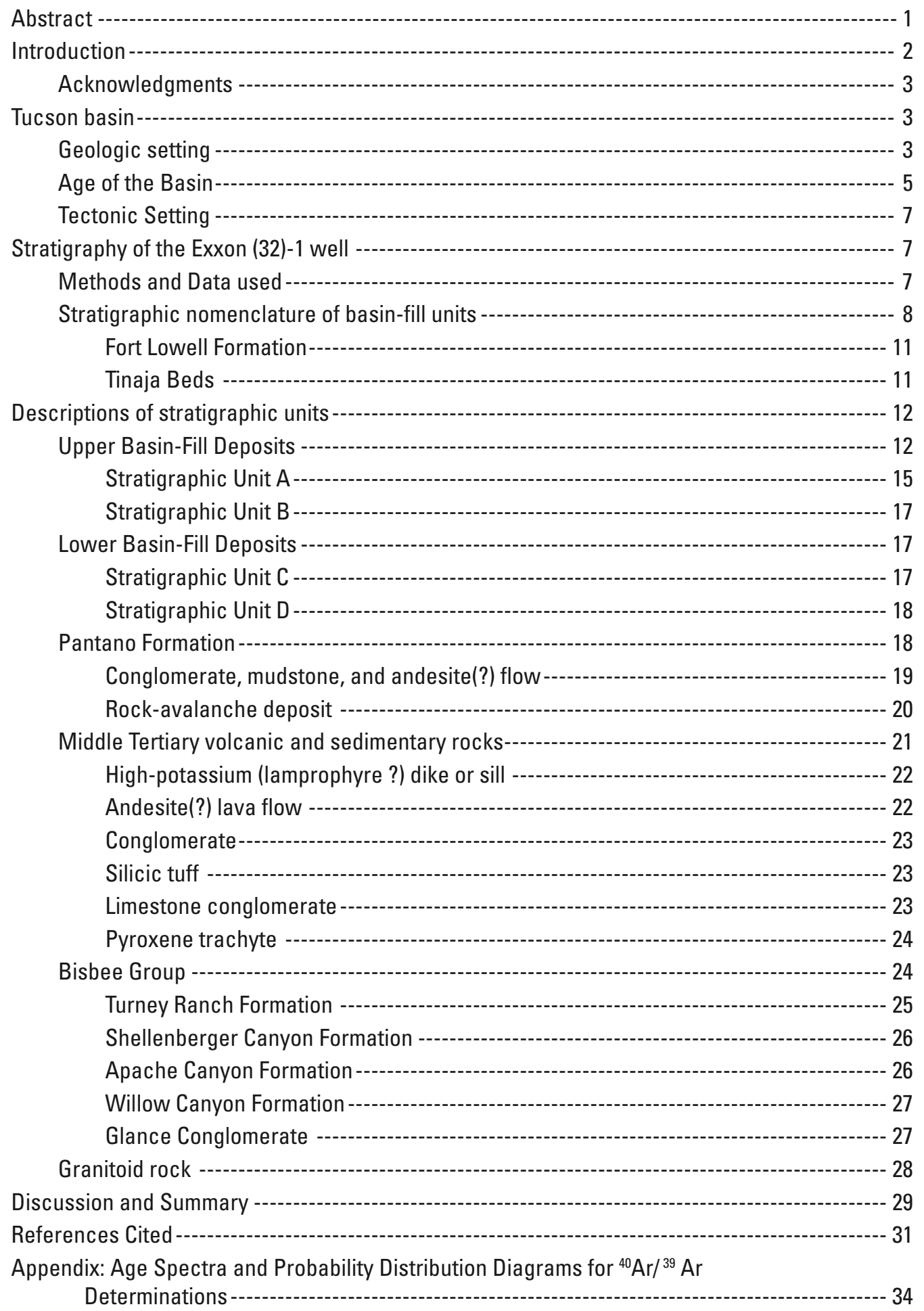




\section{Figures}

1. Map of part of southeastern Arizona showing basins, ranges, location of the Exxon State (32)-1 well in the Tucson Basin, location of the Catalina detachment fault, ash sample locations, and locations of other features mentioned in the text

2. Satellite thematic mapper image of the Tucson Basin showing the geomorphic expression of the late Pliocene to early Pleistocene Cienega Creek

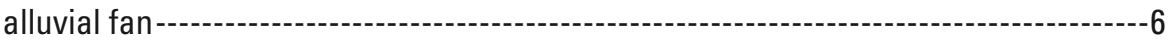

3. Map of simplified residual gravity anomalies in the Tucson Basin-------------8

4. Stratigraphic column for the Exxon State (32)-1 well --------------------------9

5. Graph showing bulk density of the sedimentary units in the Exxon State (32)-1 well --------------- 10

6-13. Geophysical logs for units in the Exxon State (32)-1 well:

6. Unit $A$, Upper basin-fill deposits--- 12

7. Unit $B$, Upper basin-fill deposits------------------------------ 13

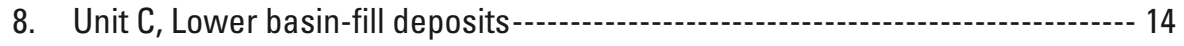

9. Unit D, Lower basin-fill deposits ---.-- 15

10. Pantano Formation --- 19

11. Middle Tertiary volcanic and sedimentary rocks---------------------------- 22

12. Bisbee Group (Turney Ranch, Shellenberger Canyon, and Apache Canyon Formations and Glance Conglomerate --- 25

13. Granitoid plutonic rock ----- 28

14-17. Age probability distribution diagrams or ideograms for dated mineral separates:

14. Feldspar separate from 613PEN97 (Nogales Formation) ---

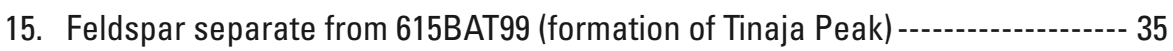

16. Sanidine separate from 616MTHOP00 (Nogales Formation)------------------ 36

17. Age spectra of biotite separates from a silicic tuff penetrated in the

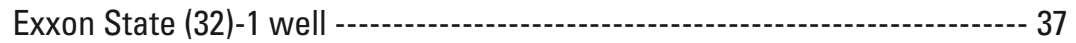

\section{Tables}

1. Summary of geophysical logs and borehole data for the Exxon State (32)-1

2. Summary of ${ }^{40} \mathrm{Ar} /{ }^{39} \mathrm{Ar}$ data and analytical methods for new radiometric ages obtained in this study

3. Names and ages (where known) of paired upper and lower basin-fill units in basins of southeastern Arizona and southwestern New Mexico 


\title{
Stratigraphy and Tectonic History of the Tucson Basin, Pima County, Arizona, Based on the Exxon State (32)-1 Well
}

\author{
By Brenda B. Houser ${ }^{1}$, Lisa Peters ${ }^{2}$, Richard P. Esser ${ }^{2}$, and Mark E. Gettings ${ }^{1}$
}

\section{Abstract}

The Tucson Basin is a relatively large late Cenozoic extensional basin developed in the upper plate of the Catalina detachment fault in the southern Basin and Range Province, southeastern Arizona. In 1972, Exxon Company, U.S.A., drilled an exploration well (Exxon State (32)-1) near the center of the Tucson Basin that penetrated 3,658 m (12,001 $\mathrm{ft}$ ) of sedimentary and volcanic rocks above granitoid basement. Detailed study of cuttings and geophysical logs of the Exxon State well has led to revision of the previously reported subsurface stratigraphy for the basin and provided new insight into its depositional and tectonic history.

There is evidence that detachment faulting and uplift of the adjacent Catalina core complex on the north have affected the subsurface geometry of the basin. The gravity anomaly map of the Tucson Basin indicates that the locations of subbasins along the north-trending axis of the main basin coincide with the intersection of this axis with west-southwest projections of synforms in the adjacent core complex. In other words, the subbasins overlie synforms and the ridges between subbasins overlie antiforms. The Exxon State well was drilled near the center of one of the subbasins.

The Exxon well was drilled to a total depth of 3,827 m $(12,556 \mathrm{ft})$, and penetrated the following stratigraphic section:

Pleistocene(?) to middle(?) Miocene upper basin-fill sedimentary rocks (0-908 $\mathrm{m}[0-2,980 \mathrm{ft}])$ lower basin-fill sedimentary rocks $(908-1,880 \mathrm{~m}$ $[2,980-6,170 \mathrm{ft}])$

lower Miocene and upper Oligocene

Pantano Formation (1,880-2,516 m [6,170-8,256 ft])

upper Oligocene to Paleocene (?) volcanic and sedimentary rocks $(2,516-3,056 \mathrm{~m}$ $[8,256-10,026 \mathrm{ft}])$

Lower Cretaceous to Upper Jurassic Bisbee Group (3,056-3,658 m [10,026-12,001 ft])

pre-Late Jurassic granitoid plutonic rock $(3,658-3,827 \mathrm{~m}[12,001-$ $12,556 \mathrm{ft}])$.

\footnotetext{
${ }^{1}$ U.S. Geological Survey, 520 North Park Avenue, Tucson, Arizona 85719 bhouser@usgs.gov

${ }^{2}$ New Mexico Bureau of Mines, 801 Leroy Place, Socorro, New Mexico 87801
}

The $1,880 \mathrm{~m}(6,170 \mathrm{ft})$ of basin-fill sedimentary rocks consist of alluvial-fan, alluvial-plain, and playa facies. The uppermost unit, a 341-m-thick (1,120-ft) lower Pleistocene and upper Pliocene alluvial-fan deposit (named the Cienega Creek fan in this study), is an important aquifer in the Tucson basin. The facies change at the base of the alluvial fan may prove to be recognizable in well data throughout much of the basin.

The well data show that a sharp boundary at $908 \mathrm{~m}(2,980$ $\mathrm{ft}$ ) separates relatively unconsolidated and undeformed upper basin fill from denser, significantly faulted lower basin fill, indicating that there were two stages of basin filling in the Tucson basin as in other basins of the region. The two stages apparently occurred during times of differing tectonic style in the region.

In the Tucson area the Pantano Formation, which contains an andesite flow dated at about $25 \mathrm{Ma}$, fills a syntectonic basin in the hanging wall of the Catalina detachment fault, reflecting middle Tertiary extension on the fault. The formation in the well is $636 \mathrm{~m}$ thick $(2,086 \mathrm{ft})$ and consists of alluvial-fan, playa, and lacustrine sedimentary facies, a lava flow, and rockavalanche deposits. Analysis of the geophysical logs indicates that a K-Ar date of 23.4 Ma reported previously for the Pantano interval of the well was obtained on selected cuttings collected from a rock-avalanche deposit near the base of the unit and, thus, does not date the Pantano Formation.

The middle Tertiary volcanic and sedimentary rocks have an aggregate thickness of $540 \mathrm{~m}(1,770 \mathrm{ft})$. We obtained a new ${ }^{40} \mathrm{Ar} /{ }^{39} \mathrm{Ar}$ age of $26.91 \pm 0.18 \mathrm{Ma}$ on biotite sampled at a depth of 2,584-2,609 m (8,478-8,560 ft) from a 169-m-thick (554-ft) silicic tuff in this interval. The volcanic rocks probably correlate with other middle Tertiary volcanic rocks of the area, and the sedimentary rocks may correlate with the Cloudburst and Mineta Formations exposed on the flanks of the San Pedro Basin to the northeast.

The Bisbee Group in the Exxon well is $602 \mathrm{~m}$ (1,975 $\mathrm{ft}$ ) thick and includes the five formations of the northeastern facies described in the Empire and Whetstone Mountains to the east. The lithologies of the five formations in the well and, hence, their inferred depositional environments are very similar to those in the type sections to the east (shale, lacustrine limestone, and conglomerates of alluvial fans); however, the section in the well is only about 5 to 30 percent as thick as in the outcrop belt, which may indicate that, at the drill site, the Bisbee subbasin did not subside as rapidly as to the east. The 
Bisbee Group was not recognized in the initial report on the stratigraphy of the Exxon well. Instead, the rocks in this interval were correlated with the Pantano Formation.

The well bottomed in $169 \mathrm{~m}(555 \mathrm{ft})$ of equigranular, slightly chloritic granitoid crystalline rock at the total depth of $3,827 \mathrm{~m}(12,556 \mathrm{ft})$. Because this granitoid rock is overlain by the Upper Jurassic(?) or Lower Cretaceous Glance Conglomerate of the Bisbee Group, it must at least be older than 138 Ma. Granitoid rocks beneath the Bisbee Group in the Cienega Gap area to the east of the Tucson Basin are Precambrian.

\section{INTRODUCTION}

In 1972, as part of an exploration program in the Basin and Range Province of southwestern Arizona, Exxon Company, U.S.A., drilled a 3,827-m-deep (12,556-ft) test well near the center of the Tucson Basin (Exxon State (32)-1, T. 16 S., R. 15 E., sec. 5, Pima County, Arizona) (fig. 1). Granitoid rock was penetrated beneath 3,658 $\mathrm{m}(12,001 \mathrm{ft})$ of Mesozoic and Cenozoic sedimentary and volcanic rocks, and the well bottomed in the granitoid rock at the total depth of $3,827 \mathrm{~m}$ $(12,556 \mathrm{ft})$. This is an important well for the Tucson Basin because, in addition to being the only one to reach granitoid crystalline rock, it is the only well that has penetrated more than about the first 1,000 meters of the 3,658-m-thick $(12,001$ $\mathrm{ft})$ overlying sedimentary and volcanic section. Unfortunately, only cuttings (no core) are available for study. However, a standard suite of geophysical logs was run, which provides coverage for nearly the entire depth of the well with the exception of the upper $61 \mathrm{~m}(200 \mathrm{ft})$ of surface casing and a 13-mthick (42-ft) interval between 899 and $912 \mathrm{~m}(2,950-2,992 \mathrm{ft})$ at the base of the second casing (table 1). The combination of geophysical log data and drill cuttings analysis provides insight into lithologic identification, sedimentologic trends, and structural interpretations that would not be given by either analysis alone.

The stratigraphy and radiometric ages obtained for this well were summarized by Eberly and Stanley (1978) and were correlated by them with surface data and with data from other deep wells in the basins of southwestern Arizona. The surface and well data, together with seismic data, provided the basis for their interpretation of the regional Cenozoic stratigraphy of southwestern Arizona. Eberly and Stanley recognized that some of the K-Ar whole-rock ages obtained on selected cuttings of volcanic rocks from Exxon State (32)-1 were out of chronologic order. To resolve this discrepancy, they inferred that rocks lower in the well (giving younger dates than rocks higher in the well) were intrusive volcanic rocks.

The present study has three objectives, which will ultimately provide part of the basis for a broader study of the Tucson Basin: (1) to interpret as much of the tectonic history of the basin as possible from the sedimentary and volcanic stratigraphy of the well, (2) to resolve some of the uncertainties associated with radiometric dates from well cuttings given in Eberly and Stanley's (1978) paper, and (3) to develop a revised stratigraphy for the Tucson Basin. To these ends, we obtained four new ${ }^{40} \mathrm{Ar} /{ }^{39} \mathrm{Ar}$ ages. Three of these are on surface exposures of ash-flow and ash-fall tuffs from lower basinfill rocks and from Pantano-age conglomerates located in the upper Santa Cruz Basin south of the Tucson Basin, and one is from a 169-m-thick (554-ft) silicic tuff in the middle Tertiary volcanic rocks in the well (table 2). In addition, we present a detailed revised stratigraphy that includes Lower Cretaceous and Upper Jurassic Bisbee Group sedimentary rocks overlying crystalline granitoid rock at the bottom of the well.

Eberly and Stanley (1978) mistakenly identified 1,142 $\mathrm{m}(3,745 \mathrm{ft})$ of Tertiary volcanic and sedimentary rocks and the Cretaceous and Jurassic Bisbee Group in the Exxon well as part of the upper Oligocene and lower Miocene Pantano Formation. This is understandable in that the focus of their

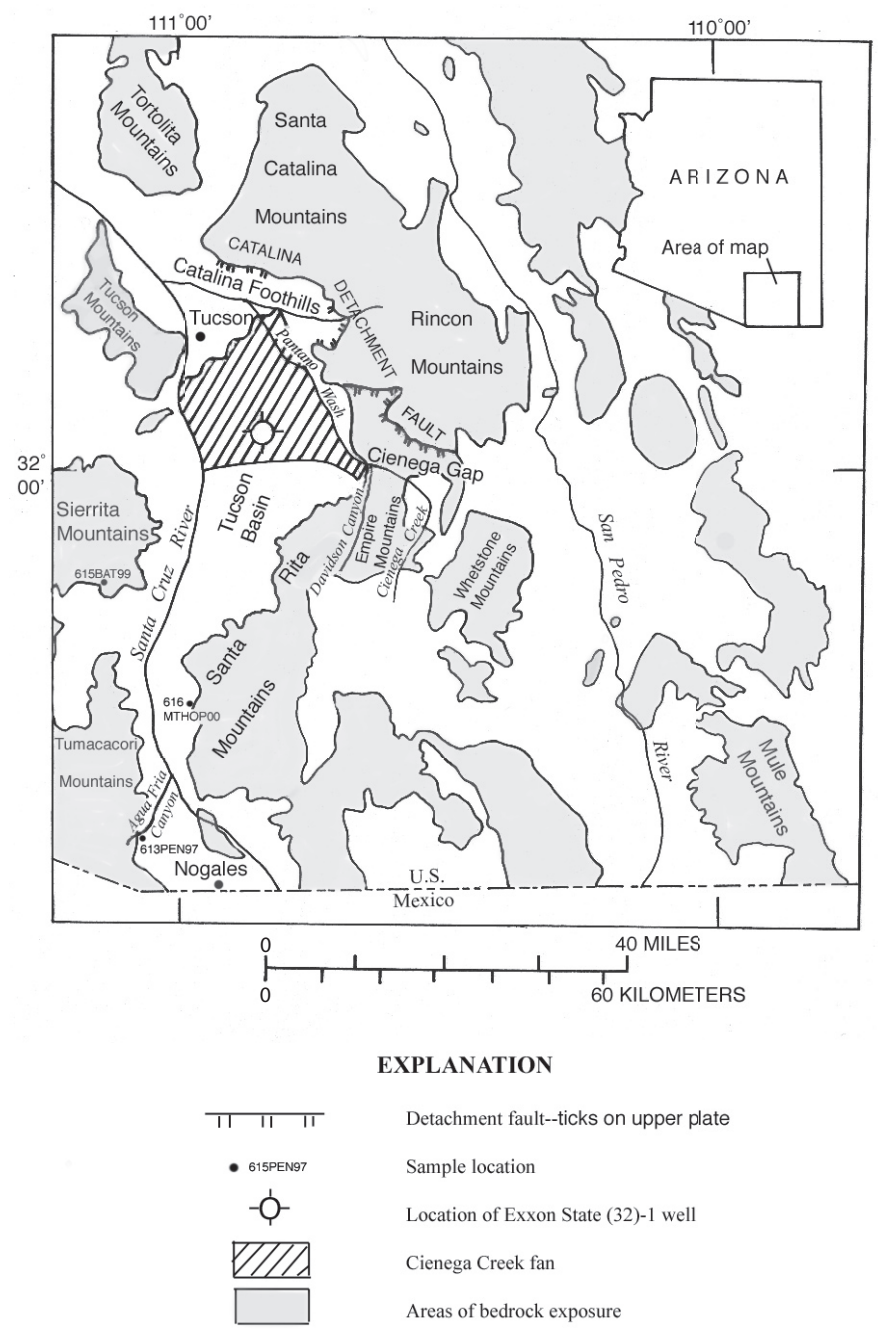

Figure 1. Part of southeastern Arizona showing basins, ranges (stippled), location of the Exxon State (32)-1 well in the Tucson Basin, location of the Catalina detachment fault (CDF, ticks on upper plate), ash sample localities (dots with sample numbers), and locations of other features mentioned in the text. Crosshatched area shows the extent of the Cienega Creek fan in the Tucson Basin. Inset map shows location of study area. 
Table 1. Summary of geophysical logs and borehole data for the Exxon State (32)-1 well.

[Casing: Surface to $61 \mathrm{~m}(199 \mathrm{ft})-40.6 \mathrm{~cm}$ (16 in) diameter; surface to $912 \mathrm{~m}(2,992 \mathrm{ft})-27.3 \mathrm{~cm}$ (10.75 in) diameter. Location data: lat $32^{\circ} 04^{\prime} 07^{\prime \prime}$ N., long $110^{\circ} 50^{\prime} 02^{\prime \prime}$ E.; NE1/4NE1/4SW1/4, sec. 5, T. 16 S., R. 15 E. Surface elevation: $876 \mathrm{~m}$ (2,873 ft). Total depth: $3,827 \mathrm{~m}(12,556 \mathrm{ft})$.

\begin{tabular}{|c|c|c|c|}
\hline Log types & Date logged & Depth interval & Borehole diameter $^{1}$ \\
\hline $\begin{array}{l}\text { Compensated gamma- } \\
\text { gamma (density), natural } \\
\text { gamma, caliper, induction, } \\
\text { spontaneous potential, } \\
\text { compensated sonic (transit } \\
\text { time) }\end{array}$ & $9-21-72$ & $\begin{array}{c}61-899 \mathrm{~m} \\
(199-2,950 \mathrm{ft})\end{array}$ & $\begin{array}{c}\text { Bit }=34.9 \mathrm{~cm} \\
(13.75 \mathrm{in})\end{array}$ \\
\hline $\begin{array}{l}\text { Compensated neutron } \\
\text { formation density, natural } \\
\text { gamma, caliper, dual } \\
\text { induction laterolog, } \\
\text { spontaneous potential, } \\
\text { compensated sonic (transit } \\
\text { time) }\end{array}$ & $12-14-72$ & $\begin{array}{c}912-3,827 \mathrm{~m} \\
(2,992-12,556 \mathrm{ft})\end{array}$ & $\begin{array}{c}\text { Bit }=24.5 \mathrm{~cm}(9.6 \mathrm{in}) \text { from } \\
912 \text { to } 2,925 \mathrm{~m} \\
(2,992-9,598 \mathrm{ft}) \\
\text { Bit }=19.4 \mathrm{~cm}(7.6 \mathrm{in}) \text { from } \\
2,925 \text { to } 3,825 \mathrm{~m} \\
(9,598-12,556 \mathrm{ft})\end{array}$ \\
\hline
\end{tabular}

${ }^{1}$ Bit size indicates minimum borehole diameter

study was the Cenozoic stratigraphy of southwestern Arizona, rather than the middle Tertiary and Mesozoic stratigraphy of southeastern Arizona. Also, as noted by Dickinson (1999), superficial similarities of some of the formations of the Bisbee Group to the Pantano Formation have resulted in exposures of the Bisbee Group being mapped as Pantano in the northeastern part of the Tucson Basin.

We also discuss the correlation of the geophysical logs with the physical properties of various rocks penetrated by the Exxon State (32)-1 well. This analysis contributes to the methodology of maximizing drill hole data and thus will be useful to other researchers where similar data are available.

\section{Acknowledgments}

We thank J.C. Matti, F.N. Houser, P.G. Vikre, and Floyd Gray for stimulating discussions and critical reviews of the manuscript. Thanks are also extended to W.R. Dickinson for his encouragement in starting this project. The late H.W. Peirce showed one of us (Houser) important conglomerate exposures in the northeastern part of the Tucson Basin. T.G. McGarvin provided assistance in accessing the well cuttings at the Arizona Geological Survey core and cuttings repository. We thank Walter A. Harrison of Caterpillar Inc. for allowing us to conduct field work on the Tucson Proving Ground southeast of the Sierrita Mountains where we studied the formation of Tinaja Peak and collected an ash sample.

\section{TUCSON BASIN}

\section{Geologic Setting}

The Tucson Basin is a large structural basin in the southern Basin and Range Province of the southwestern United
States, a region of northwest-trending sediment-filled basins separated by fault-bounded mountain ranges, which form the characteristic basin-and-range topographic expression of late Tertiary extension (fig. 1). The Tucson Basin is 15 to $40 \mathrm{~km}$ wide (10 to $25 \mathrm{mi}$ ), about $80 \mathrm{~km}$ long (50 mi), generally crescent shaped (concave to the west), and forms part of the valley of the north-flowing Santa Cruz River. The elevation of the floor of the basin near central Tucson is about $727 \mathrm{~m}(2,385 \mathrm{ft})$ above sea level.

Mountain ranges on the north and east side of the Tucson Basin are the Santa Catalina and Rincon Mountains, respectively, with elevations up to $2,791 \mathrm{~m}(9,157 \mathrm{ft})$. These two ranges make up the Catalina core complex, which is bounded on the southwest by the Catalina detachment fault (Dickinson, 1991). Cienega Gap is a broad bedrock saddle between the Rincons on the north and the Santa Rita Mountains on the south. The Santa Rita Mountains are as high as 2,881 m $(9,453 \mathrm{ft})$ and border the Tucson Basin on the east and south. The Sierrita and Tucson Mountains on the west side of the basin are about 1,800 $\mathrm{m}(5,900 \mathrm{ft})$ and 1,430 $\mathrm{m}(4,700 \mathrm{ft})$ high, respectively, more than $1,000 \mathrm{~m}(3,300 \mathrm{ft})$ lower than the mountains on the north and east sides.

A wide range of lithologies is present in the mountains bordering the Tucson Basin, including Precambrian and Laramide-age (latest Cretaceous and Paleocene) granitoid plutonic rocks, Paleozoic sedimentary rocks, and volcanic and sedimentary rocks of Mesozoic, Laramide, and middle Tertiary age (Drewes, 1971a,b, 1977; Cooper, 1973; Banks, 1974; Reynolds, 1988; Lipman, 1993; Force, 1997). At the present erosion level, granitoid gneiss is the predominant lithology in the Catalina core complex, but before and during late Tertiary uplift and unroofing of the core complex, other lithologies had to be present, particularly Tertiary and Cretaceous volcanic rocks and Paleozoic limestones of the hanging wall of the 
Table 2. Summary of ${ }^{40} \mathrm{Ar} /{ }^{39} \mathrm{Ar}$ data and analytical methods for new radiometric ages obtained in this study.

\begin{tabular}{|c|c|c|c|c|c|c|c|}
\hline $\begin{array}{l}\text { Sample } \\
\text { Number }\end{array}$ & $\begin{array}{c}\text { Stratigraphic } \\
\text { unit }\end{array}$ & $\begin{array}{l}\text { Latitude } \\
\text { Longitude }\end{array}$ & Irradiation ${ }^{1}$ & Mineral & Analysis 2,3 & $\begin{array}{l}\text { Number } \\
\text { of steps }\end{array}$ & $\begin{array}{c}\text { Age }(\mathrm{Ma})^{4} \\
(\mathrm{MSWD}) \\
\end{array}$ \\
\hline 613PEN97 & $\begin{array}{l}\text { Nogales } \\
\text { Formation }\end{array}$ & $\begin{array}{r}31^{\circ} 26^{\prime} 02^{\prime \prime} \\
111^{\circ} 02^{\prime} 50^{\prime \prime}\end{array}$ & NM-82 & Sanidine & $\begin{array}{l}\text { Laser } \\
\text { fusion }\end{array}$ & 14 & $\begin{array}{c}13.23+0.10 \\
(1.6)\end{array}$ \\
\hline 615ВАТ99 & $\begin{array}{l}\text { formation of } \\
\text { Tinaja Peak }\end{array}$ & $\begin{array}{l}31^{\circ} 50^{\prime} 10^{\prime \prime} \\
111^{\circ} 08^{\prime} 27^{\prime \prime}\end{array}$ & NM-119 & Sanidine & $\begin{array}{l}\text { Laser } \\
\text { fusion }\end{array}$ & 3 & $\begin{array}{c}24.70+0.19 \\
(0.5)\end{array}$ \\
\hline 616МTHOР00 & $\begin{array}{l}\text { Nogales } \\
\text { Formation }\end{array}$ & $\begin{array}{r}31^{\circ} 38^{\prime} 29^{\prime \prime} \\
110^{\circ} 58^{\prime} 38^{\prime \prime}\end{array}$ & NM-129 & Sanidine & $\begin{array}{l}\text { Laser } \\
\text { fusion }\end{array}$ & 2 or 12 & $\begin{array}{c}15.53+0.38 \\
\text { or } \\
17.38+0.77 \\
(18)\end{array}$ \\
\hline $\begin{array}{l}2,584-2,609 \\
\text { m Exxon State } \\
\text { (32)-1 }\end{array}$ & $\begin{array}{l}\text { Middle Ter- } \\
\text { tiary } \\
\text { volcanic } \\
\text { rocks }\end{array}$ & $\begin{array}{l}32^{\circ} 04^{\prime} 07^{\prime \prime} \\
110^{\circ} 50^{\prime} 02^{\prime \prime}\end{array}$ & NM-110 & Biotite & $\begin{array}{l}\text { Furnace } \\
\text { step heat }\end{array}$ & 7 & $\begin{array}{c}26.91+0.19 \\
(1.5)\end{array}$ \\
\hline
\end{tabular}

'Sample preparation and irradiation: Mineral separates were prepared using standard crushing, heavy liquid, and hand-picking techniques. The separates were loaded into a machined Al disc and irradiated for either 7 or 14 hours in D-3 position at the Nuclear Science Center, College Station, Texas. Neutron flux monitor is Fish Canyon Tuff sanidine (FC-1) with an assigned age of 27.84 Ma (Deino and Potts, 1990) relative to Mmhb-1 at 520.4 Ma (Samson and Alexander, 1987).

${ }^{2}$ Instrumentation: Mass Analyzer Products 215-50 mass spectrometer on line with automated all-metal extraction system. Biotite samples step-heated in Mo double-vacuum resistance furnace; heating duration 8 minutes. Reactive gases removed by reaction with three SAES GP-50 getters, two operated at about $450^{\circ} \mathrm{C}$ and one at $20^{\circ} \mathrm{C}$. Gas also exposed to a W filament operated at about $2,000^{\circ} \mathrm{C}$. Single sanidine crystals were fused by a 50 -watt $\mathrm{Synrad}^{\mathrm{CO}} \mathrm{O}_{2}$ laser. Reactive gases removed during a 1-minute reaction with two SAES GP-50 getters, one operated at about $450^{\circ} \mathrm{C}$ and one at $20^{\circ} \mathrm{C}$. Gas also exposed to a W filament operated at about $2,000^{\circ} \mathrm{C}$ and a cold finger operated at $-140^{\circ} \mathrm{C}$.

${ }^{3}$ Analytical parameters: Electron multiplier sensitivity averaged $2.31 \times 10-16 \mathrm{moles} / \mathrm{pA}$ for the furnace and $1.25 \times 10-16$ for the laser. Total system blank and background for the furnace averaged $5,030,44.1,0.9,5.6,18.2 \times 10-18$ moles and $700,15,1.8,3.5,4.2 \times 10-18$ moles for the laser at masses 40, 39, 38, 37, and 36, respectively. J-factors determined to a precision of $\pm 0.1 \% \mathrm{by} \mathrm{CO}_{2}$ laser-fusion of four single crystals from each of four or six radial positions around the irradiation tray. Correction factors for interfering nuclear reactions were determined using $\mathrm{K}$-glass and $\mathrm{CaF}_{2}$, and are as follows: $\left({ }^{40} \mathrm{Ar} /{ }^{39} \mathrm{Ar}\right) \mathrm{K}=$ $0.00020 \pm 0.0003 ;\left({ }^{36} \mathrm{Ar} /{ }^{37} \mathrm{Ar}\right) \mathrm{Ca}=0.00026 \pm 0.00002$; and $\left({ }^{39} \mathrm{Ar} /{ }^{37} \mathrm{Ar}\right) \mathrm{Ca}=0.00070 \pm 0.00005$.

${ }^{4} \mathrm{Age}$ calculations: Total gas ages and errors calculated by weighting individual steps by the fraction of ${ }^{39} \mathrm{Ar}$ released. Plateau ages calculated for the indicated steps by weighting each step by the inverse of the variance. Plateau age errors calculated using the method of Taylor (1982). Mean sum weighted deviate (MSWD) values are calculated forn-1 degrees of freedom for plateau ages. If the MSWD is outside the $95 \%$ confidence window (Mahon, 1996, table 1), the error is multiplied by the square root of the MSWD. Decay constants and isotopic abundances after Steiger and Jager (1977). All final errors reported at $\pm 2 \sigma$.

detachment fault. These rocks were shed into the northern half of the basin in large quantity, both as rock avalanches and as fluvial sediments. The erosional sequence is clearly demonstrated in the clast composition of lower basin-fill conglomerate units exposed in the area termed the Catalina Foothills along the north side of the Tucson basin (fig. 1) (Voelger, 1953; Pashley, 1966; Dickinson, 1999). The oldest unit in the Foothills area was named the lower Rillito Formation by Voelger (1953) and the type I Rillito beds by Pashley (1966). It is probably equivalent to the middle Tertiary Pantano Formation described in Cienega Gap by Finnell (1970b) and Balcer (1984) and contains clasts of volcanic rock, limestone, quartzite, and schist but no gneiss. The progressively younger lower basin-fill rocks were named the middle and upper Rillito Formation by Voelger (1953), the type II and III Rillito beds by Pashley (1966), and the Swan-Craycroft gravels by Dickinson (1999). These rocks contain increasing amounts of gneissic clasts and proportionally decreasing amounts of other clast lithologies upward in the section until, finally, the Pleistocene fans are composed dominantly of granitoid gneiss clasts.

Except for discontinuous exposures of more consolidated lower basin-fill rocks next to the mountains, exposures in the Tucson Basin consist of slightly dissected upper basin-fill sediments, probably late Pliocene to early Pleistocene in age, variously covered by middle Pleistocene through Holocene surficial materials (Pearthree and others, 1988). Holocene alluvial deposits of the Santa Cruz River occupy the western edge of the basin. No vertebrate fossils and only one tephra bed (which contains no datable minerals) have been found in the Tucson basin fill, partly because of a paucity of exposures, but chiefly because the rocks that are exposed were deposited in fairly high-energy fluvial environments where vertebrate remains and tephra beds are unlikely to be preserved.

Most of the basin, from the mouth of Cienega Creek west to the Santa Cruz River and northwest to Tucson, is occupied by a large upper Pliocene to lower Pleistocene alluvial fan 
(herein termed the Cienega Creek fan) composed of detritus eroded from Davidson Canyon, Cienega Gap, and the lower part of Cienega Creek Valley (fig. 2). Dickinson (1999, p. 4) noted that the "floor of the northeastern corner of the Tucson basin is a sediment apron in the form of a half fan $* * *$ with its apex where Pantano Wash exits from Cienega Gap." However, lacking subsurface data, he apparently did not recognize that the near-surface sediment is actually part of a thick upper basin-fill alluvial fan and not just a sediment apron with the form of a fan. The surface morphology of the alluvial fan shows clearly on figure 2 , which is a thematic mapper image of the Tucson basin and of areas to the southeast that were the source of the fan sediment. Analysis of cuttings and logs of the Exxon State (32)-1 well indicate that at the well site the fan is about $340 \mathrm{~m}(1,120 \mathrm{ft})$ thick, and the gamma ray log indicates that tephra beds are present in a finer-grained facies of basin-fill deposits just $10 \mathrm{~m}$ below the base of the alluvial fan.

\section{Age of the Basin}

Basin-range taphrogeny and the formation and filling of the Tucson Basin resulted from crustal extension directed dominantly east-northeast/west-southwest on a regional scale during the late Cenozoic. Normal faulting, basin subsidence, and basaltic and bimodal basalt-rhyolite volcanism began in southeastern Arizona as early as $17 \mathrm{Ma}$ and continued into the late Pliocene and early Pleistocene.

Basaltic or bimodal basalt-rhyolite magmatism is commonly taken to be an indicator of crustal extension and, thus, the oldest basaltic lavas or high-silica ash-flow tuffs associated with a basin and its basin fill will give a minimum age for basin formation. For example, in the Safford Basin and adjacent Gila, Whitlock, and Peloncillo Mountains, about 150 $\mathrm{km}$ northeast of the Tucson Basin, numerous radiometric dates show that the change from intermediate composition volcanism, characteristic of the mid-Tertiary volcanic period in the southern Basin and Range (Shafiqullah and others, 1978), to basaltic and bimodal volcanism occurred at about $17 \mathrm{Ma}$ (Richter and others, 1981; Richter and others, 1983; Houser and others, 1985; Wrucke and others, 2004). The oldest dated true basalt flows in southeastern Arizona are in the Whitlock Mountains, where K-Ar ages were obtained of 16.6 to $16.2 \mathrm{Ma}$ (Richter and others, 1981).

The maximum age of the beginning of basin-range extension and formation of the Tucson Basin is similar to that of the Safford Basin, but it is not as tightly constrained. The youngest dates reported for middle Tertiary intermediate composition volcanic rocks in the ranges surrounding the Tucson Basin are 20.3 $+3.0 \mathrm{Ma}$ in the Tucson Mountains (Marvin and others, 1978; Lipman, 1993) and 23.7 Ma in the Sierrita Mountains (Cooper, 1973), whereas the oldest dated tuff associated with lower basin-fill sedimentary deposits of the Nogales Formation in the upper Santa Cruz Basin (south of the Tucson Basin) is $15.53+0.38 \mathrm{Ma}$ (see below).
The Nogales Formation is a fluvial middle to upper Miocene unit in the upper Santa Cruz Basin named by Simons (1974) for exposures near Nogales. Drewes (1971b) extended the geographic range of the unit to include well indurated faulted alluvial-fan deposits exposed at the edge of the upper Santa Cruz Basin on the west side of the Santa Rita Mountains. In this study, ${ }^{40} \mathrm{Ar} /{ }^{39} \mathrm{Ar}$ ages were obtained on sanidine from two tuffs interbedded near the base of the Nogales Formation on either side of the upper Santa Cruz Basin (fig. 1; table 2; figs. 14 and 16 in appendix).

A sample (MTHOP00) for dating was collected from a relatively unreworked ash-fall tuff bed $0.5 \mathrm{~m}$ thick in a highly tuffaceous conglomerate facies, probably within $100 \mathrm{~m}$ of the base of the Nogales Formation, in Cottonwood Canyon on the western side of the Santa Rita Mountains (fig. 1). The stratigraphic position of the tuff bed relative to the base of the Nogales Formation is estimated from well data. In nearby surface exposures, the Nogales is in fault contact chiefly with Precambrian gneiss and with minor Late Cretaceous diorite (Drewes, 1971b). Unfortunately, small crystal size of this sample led to analytical problems. In addition, the age probability distribution diagram (fig. 16) shows that the sample contained probable xenocrystic material. The most likely age of the ash bed we sampled is $15.53+0.38 \mathrm{Ma}$, based on the weighted mean of the two youngest sanidine crystals in the sample. The older date $(17.38 \pm 0.77 \mathrm{Ma})$, based on the weighted mean of the whole sample (fig. 16), may represent the age of the dominant tuff of the reworked tuffaceous matrix of the conglomerate. It is possible that this older tuff could be part of a bimodal eruption sequence and, thus, could date more closely the beginning of Basin and Range extension in the upper Santa Cruz Basin, but in the absence of unreworked exposures, this relationship is conjectural.

The second date was obtained on sanidine from an ashflow tuff bed about $5 \mathrm{~m}$ thick interbedded with conglomerate of the Nogales Formation on the west side of the upper Santa Cruz Valley in Agua Fria Canyon, $70 \mathrm{~km}$ south of the Exxon well site (613PEN97 in fig. 1). The base of the conglomerate is not exposed at the sample locality, although field relations indicate that the tuff is fairly near the bottom of the Nogales Formation. About $3 \mathrm{~km}$ to the northwest, the conglomerate and tuff are in fault contact with middle Tertiary rhyolite of the Atascosa Mountains. The ${ }^{40} \mathrm{Ar} /{ }^{39} \mathrm{Ar}$ date obtained in this study, on sanidine from pumice in the ash-flow tuff, is $13.23 \pm 0.10 \mathrm{Ma}$ (table 2; fig. 14 ). This agrees well with the whole-rock K-Ar age reported by Simons (1974) of $12.6 \pm 0.8 \mathrm{Ma}$ from basalt interbedded near the base of the conglomerate about $1 \mathrm{~km}$ to the northeast. The ash-flow tuff and basalt samples, closely positioned in age and space, suggest the possible presence of a small bimodal eruptive center buried within or beneath the lower basin-fill deposits of the upper Santa Cruz Basin to the east.

Scarborough and Peirce (1978) quoted a K-Ar date of 11.6 Ma for the beginning of extension in the Tucson Basin. The date was obtained on drill cuttings from the Exxon well that (based on Eberly and Stanley's (1978) stratigraphic interpretation) were collected from the top of the volcanic section 

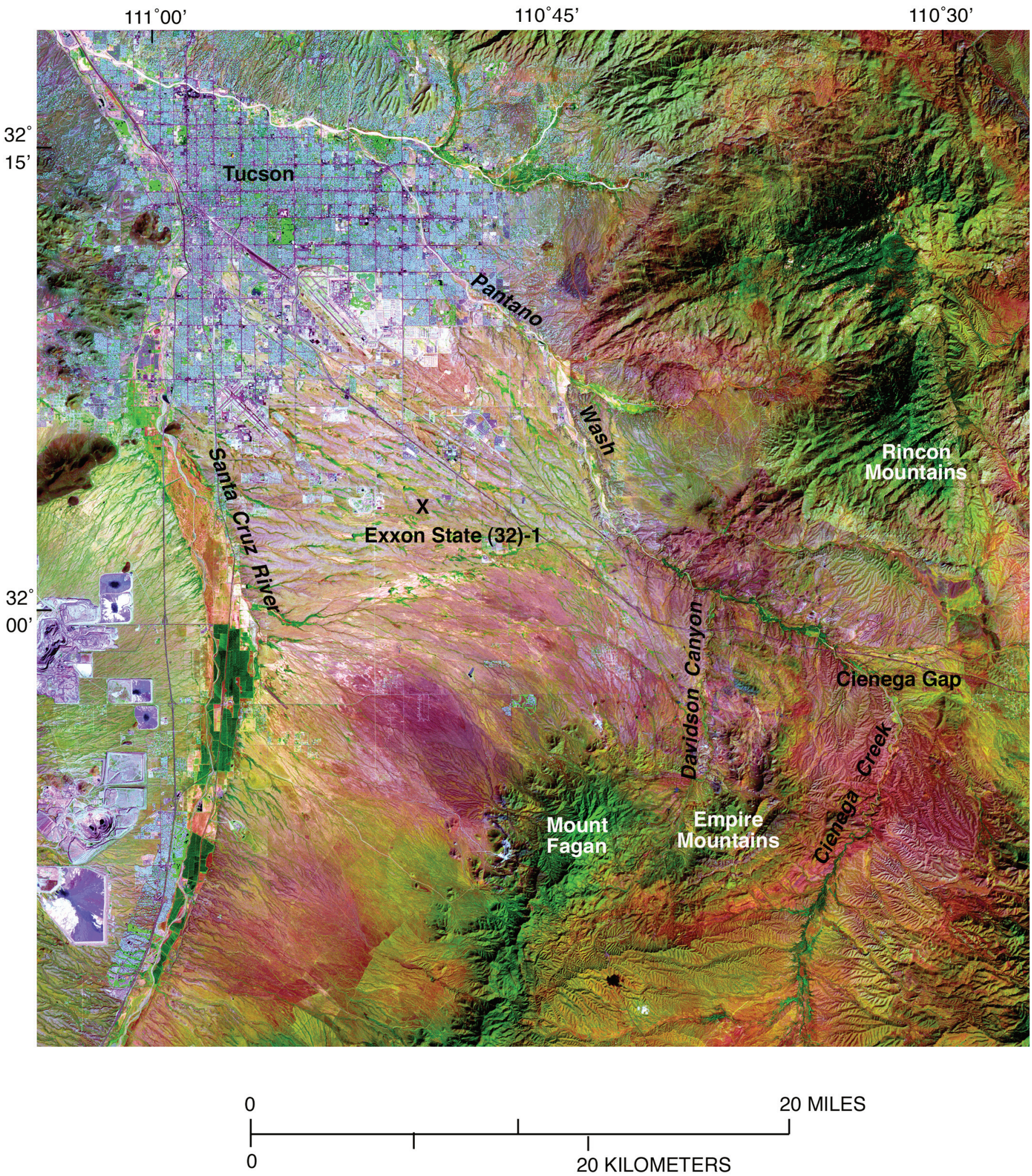

Figure 2. Landsat satellite thematic mapper (TM) image of the Tucson Basin showing the geomorphic expression of the late Pliocene to early Pleistocene Cienega Creek alluvial fan. The fan head is at the eastern side of the basin near the mouth of Cienega Creek, and the toe is within the developed southeastern outskirts of Tucson. The fan is composed of sediments derived from basin-fill deposits and bedrock eroded from the Davidson Canyon and Cienega Creek drainage basins. The Cienega Creek fan is the youngest unit penetrated by the Exxon well, and is about $340 \mathrm{~m}(1,120 \mathrm{ft})$ thick at the well site (locality marked by an X). 
just beneath the basin fill at a depth of 2,192 m (7,191 ft) (fig. 4) (Damon and others, 1996). However, in our revised interpretation of the stratigraphic section, this depth corresponds to playa-facies sediments in the Pantano Formation, so the selected cuttings that were dated probably were conglomerate clasts from uphole contamination.

Soil studies and maps of surficial deposits in the Tucson Basin and upper Santa Cruz Valley (Pearthree and others, 1988; Helmick, 1986) show that there are no basin-filling deposits younger than about earliest Pleistocene, suggesting that crustal extension and basin subsidence in southeastern Arizona were waning by this time as noted by Machette and others (1986) and Menges and Pearthree (1989). Although Pleistocene fault scarps of the Santa Rita Fault Zone on the eastern piedmont of the Tucson and upper Santa Cruz Basins (Drewes, 1971a, b) are evidence of continued extension, Pearthree and Calvo (1987) have estimated a fault recurrence interval of about $200 \mathrm{k} . \mathrm{y}$. on the fault zone, indicating relative quiescence. Through-flowing drainage by the Santa Cruz River was probably initiated near the beginning of the Pleistocene as basin subsidence slowed, but, as in the case of the fault scarps, the modern river also provides evidence of continuing minor tectonic subsidence. Gettings and Houser (1997) noted that the gradient of the upper Santa Cruz River flood plain increases where the river crosses buried bedrock highs between subbasins. They suggested the changes in gradient are caused by differential movement of subbasins relative to intervening bedrock highs during the Holocene.

\section{Tectonic Setting}

The Tucson Basin lies in the hanging wall of the early Miocene Catalina detachment fault (Dickinson, 1991). In fact, the detachment fault more or less coincides with the topographic boundary of the basin adjacent to the Santa Catalina and Rincon Mountains (fig. 1), although aeromagnetic data (Sweeney, 2000) indicate that the middle Miocene basin-range fault along the northern side of the basin in the Catalina Foothills area lies about $1.5 \mathrm{~km}(1 \mathrm{mi})$ southwest of the surface trace of the detachment fault.

Like mountain ranges, which are marked by visible saddles and peaks, basins have deeper parts termed subbasins separated by buried bedrock highs. However, whereas the topography of ranges is shaped by both erosion and tectonics, the topographic shape of the basins is chiefly a function of tectonic forces. The location and shape of buried subbasins and intervening bedrock highs are delineated by drilling and by gravity, magnetic, and electrical data. The location of subbasins within extensional basins in the southern Basin and Range Province commonly appears to have been controlled by activation of pre-existing structures. For example, in the upper Santa Cruz Valley, the northwestern extension of the Mount Benedict Fault crosses the valley obliquely and separates the Rio Rico and Tubac subbasins (Gettings and Houser, 1997). In the Tucson Basin, there is evidence that detachment faulting and uplift of the core complex, in addition to creating the Santa Catalina and Rincon Mountains, have had an effect on the subsurface geometry of the basin. Figure 3 is a simplified residual gravity anomaly map of the basin (modified from Davis, 1971). The schematic gravity anomaly contours indicate that, although the axis of the basin is generally north trending, the locations of the subbasins along the axis coincide with the intersection of the basin axis with west-southwest projections of the synforms of the core complex. Projections of the antiforms, or mullions, of the core complex correspond to ridges between the subbasins. This geometry is analogous to the sediment-filled basins present in the synforms between mullions of the Harcuvar, Rawhide, and Buckskin Mountains core complexes in west-central Arizona (Spencer and Reynolds, 1989) and demonstrates that the tectonic influence of the Catalina core complex may extend into the subsurface at least as far west as the axis of the Tucson Basin.

This correlation of the location of late Tertiary subbasins of the Tucson Basin with underlying synforms of the Catalina core complex implies that the southwestern flank of the core complex was tectonically active when the subbasins were being filled, at least during the early stages in middle to late Miocene time. The magnitude of differential displacement between the subbasins and intervening ridges is not trivial. On the basis of density analysis of gravity anomaly data, Litinsky (1989) estimated the topographic relief between subbasins and ridges in the Tucson Basin to range from 1 to $3 \mathrm{~km}$ (0.6 to $1.8 \mathrm{mi})$.

\section{STRATIGRAPHY OF THE EXXON STATE (32)-1 WELL}

\section{Methods and Data Used}

This study involved a detailed microscopic examination of drill cuttings from the Exxon State (32)-1 well. The sampled interval begins at $70 \mathrm{~m}(230 \mathrm{ft})$ and extends through the total depth of the well at 3,827 m (12,556 ft). Names and numerical designations of colors of the cuttings are based on the Munsell system as estimated from the rock color chart (Goddard and others, 1975). Geophysical logs were invaluable in the interpretation of the stratigraphy and sedimentology of the rock units represented by the cuttings and provide much of the basis for tectonic interpretations. The logs were obtained by a commercial well-logging company, Schlumberger Well Services. Table 1 summarizes the depth intervals for which the logs were run and the borehole and casing diameters. Discussions of the interpretation of geophysical logs can be found in Keys and MacCary (1971), Telford and others (1976), Hilchie (1978), and Merkel (1979).

Radiometric ages of stratigraphic units related to the Tucson Basin have been determined by both the K/Ar method (Cooper, 1973; Eberly and Stanley, 1978; and Shafiqullah and others, 1978) and the ${ }^{40} \mathrm{Ar} /{ }^{39} \mathrm{Ar}$ method (reported in this paper). The ${ }^{40} \mathrm{Ar} /{ }^{39} \mathrm{Ar}$ dates (one from interval 2,584-2,609m [8,478- 
8,560 ft] of the Exxon State (32)-1 well and three from surface rocks correlated with units present in the well) were obtained by the New Mexico Geochronology Research Laboratory. A summary of the ${ }^{40} \mathrm{Ar} /{ }^{39} \mathrm{Ar}$ results can be found in table 2 . The complete set of ${ }^{40} \mathrm{Ar} /{ }^{39} \mathrm{Ar}$ analytical data can be found in the appendix.

Two problems with the cuttings were recognized that bear on the anomalously young K-Ar ages obtained from selected cuttings in Eberly and Stanley's (1978) study: (1) In some cases, the cuttings in the sample vials do not match the lithologies indicated by the geophysical logs, suggesting that in these cases the cuttings in the vials are from some other interval and may have been improperly bagged at the drill site or later. (2) The biggest
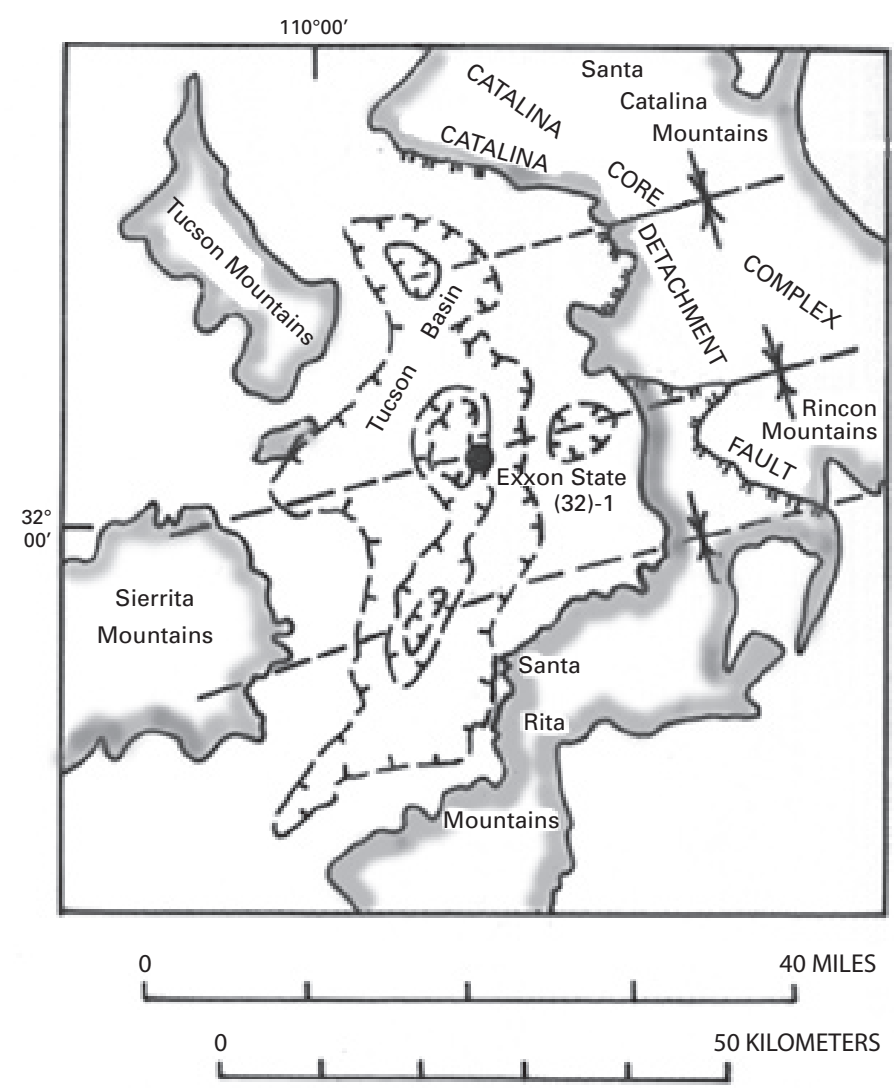

EXPLANATION

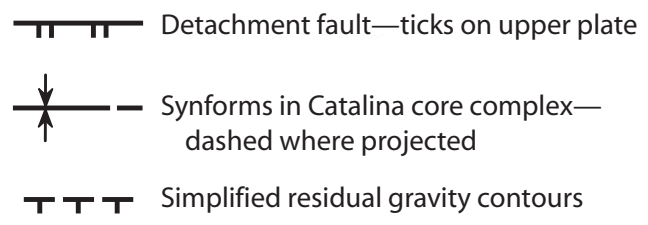

Figure 3. Simplified residual gravity anomalies in the Tucson Basin (modified from Davis, 1971). The schematic gravity contours correlate with depth of basin fill. Note that, although the axis of the basin is generally north trending, the locations of the subbasins along the axis correspond to the intersection of the basin axis with west-southwest projections of the synforms of the Catalina core complex. The antiforms, or mullions, correspond to ridges separating the subbasins. problem with the cuttings is contamination from washing out of sediments farther up the well. The amount of contamination is variable and could be estimated with a moderate degree of certainty in monolithologic intervals. For example, the pyroxene trachyte between 2,897 $\mathrm{m}$ and 3,056 $\mathrm{m}$ (9,504-10,026 ft) is a monolithologic interval directly below poorly consolidated limestone conglomerate (2,753-2,897 m [9,032-9,504 ft]). Contamination in the trachyte interval from the conglomerate is estimated to be as much as 50 percent. Selected cuttings from the trachyte interval yielded two anomalously young K-Ar dates (Eberly and Stanley, 1978); these anomalously young dates are presumed to have been due to contamination.

In contrast, contamination was not a significant problem in the monolithologic silicic tuff interval dated in this study (2,584-2,753 m [8,478-9,032 ft]) (table 2). It was found to contain only an estimated 10 percent contaminant chips consisting of mudstone, volcanic lithics, and rounded quartz grains. Contamination in this interval is minimal because the overlying lower basin-fill units and Pantano Formation are relatively well consolidated. In addition, the second casing was set at $912 \mathrm{~m}(2,992 \mathrm{ft})$, just below the base of the loosely consolidated upper basin-fill units (figs. 4 and 5), which effectively eliminated contamination from these materials. Biotite was the mineral dated in the silicic tuff interval and, although biotite is present in the uphole sedimentary rock cuttings above about 2,200 $\mathrm{m}(7,200 \mathrm{ft})$, the dated sample consisted only of euhedral biotite books with adhering tuff.

Thickness estimates for fault zones and dikes interpreted from the geophysical logs are maximum values because the attitudes of the faults and dikes relative to the logging tools and well bore are not known. In general, the steeper the attitude, the thicker the feature will appear to be. Down section from the upper basin-fill units (which presumably are flat lying), thickness estimates of bedding and of stratigraphic units also are maximum values if the units have been tilted.

\section{Stratigraphic Nomenclature of Basin-Fill Units}

The most comprehensive record of the stratigraphy of the Tucson Basin is provided by the Exxon State (32)-1 well (fig. 4). The record of the upper Cenozoic sedimentary basin-fill units is particularly good because the well was drilled near the deep part of one of the subbasins as indicated by the residualgravity anomaly map (fig. 3). This location provides a thick, relatively complete sedimentary section having few hiatuses or complicating influxes of locally derived sediment. In the upper 1,880 m (6,170 ft) of sediments in the Tucson Basin, four units are here recognized and informally designated as Units A and B of the upper basin fill and Units C and D of the lower basin fill.

The separation into upper and lower basin fill is based on age, degree of consolidation, and amount of deformation (figs. 4, 5; table 3). Where suitable materials are available for dating elsewhere in the southern Basin and Range Province of southeastern Arizona and southwestern New Mexico, upper 


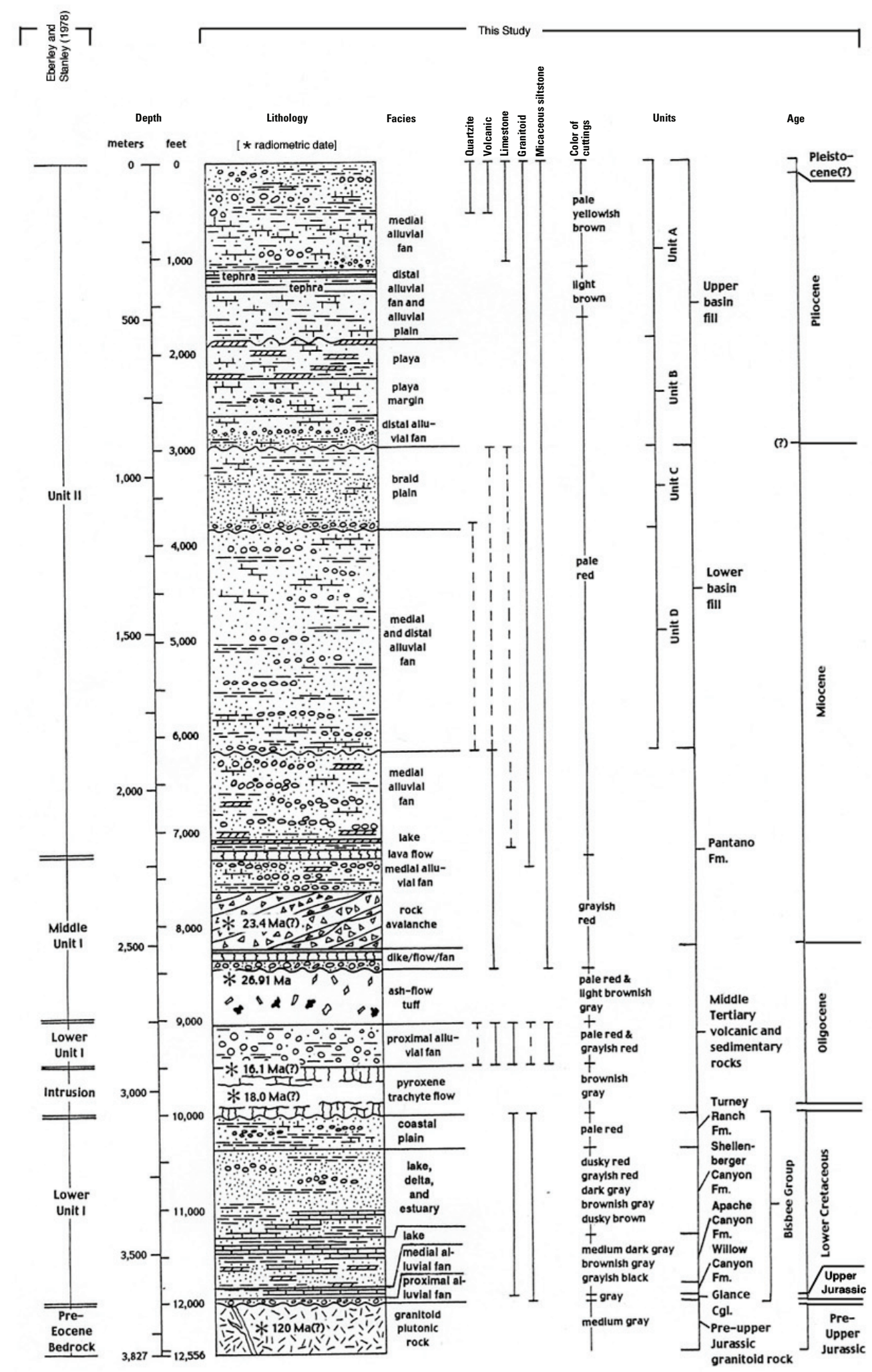

Figure 4. Stratigraphic column for the Exxon State (32)-1 well. Dashed lines under clast-lithology heading indicate intervals where the lithology is rare. Queried radiometric dates are from Eberly and Stanley (1978); the $26.91 \mathrm{Ma}$ age date on the ash-flow tuff was obtained in this study. The stratigraphic correlation of Eberley and Stanley (1978) for southwestern Arizona is shown at the left. In the Exxon well, they correlated Unit II with basin fill, middle Unit I with middle Tertiary volcanic and sedimentary rocks, and lower Unit I with the Pantano Formation. 
basin-fill deposits generally are found to be Pleistocene and Pliocene in age, poorly to moderately consolidated, flat lying or nearly so, and broken by only a few faults, most of which have relatively small displacement. Lower basin-fill deposits generally are late to middle Miocene in age, moderately consolidated, slightly to moderately deformed with dips of as much as $15^{\circ}$ (higher adjacent to faults), and broken by numerous faults having small displacement and by some faults with very large displacement. Examples of paired upper and lower basin-fill units in nearby basins of Arizona and New Mexico are given in table 3 .

The distribution of facies of both upper and lower basinfill sedimentary rocks in the region indicates that they were deposited in basins having more or less their modern configurations. Clasts in upper basin-fill conglomeratic beds were derived from adjacent ranges, whereas lower basin-fill conglomeratic deposits (particularly near the base of the units) commonly contain lithologies that are not present in the adjacent ranges and(or) do not contain lithologies that are locally abundant. This is a consequence of erosional stripping and reflects the greater age of the lower basin fill relative to the upper fill. In outcrops near basin margins, the contact between upper and lower basin-fill deposits commonly is sharply gradational or paraconformable.

Although Davidson (1973) named two stratigraphic units in the Tucson Basin (Fort Lowell Formation and Tinaja beds) that correlate, in part, with the upper and lower basin-fill deposits described above, we prefer to use the more general and informal terminology of upper and lower basin fill in this report for reasons discussed below.

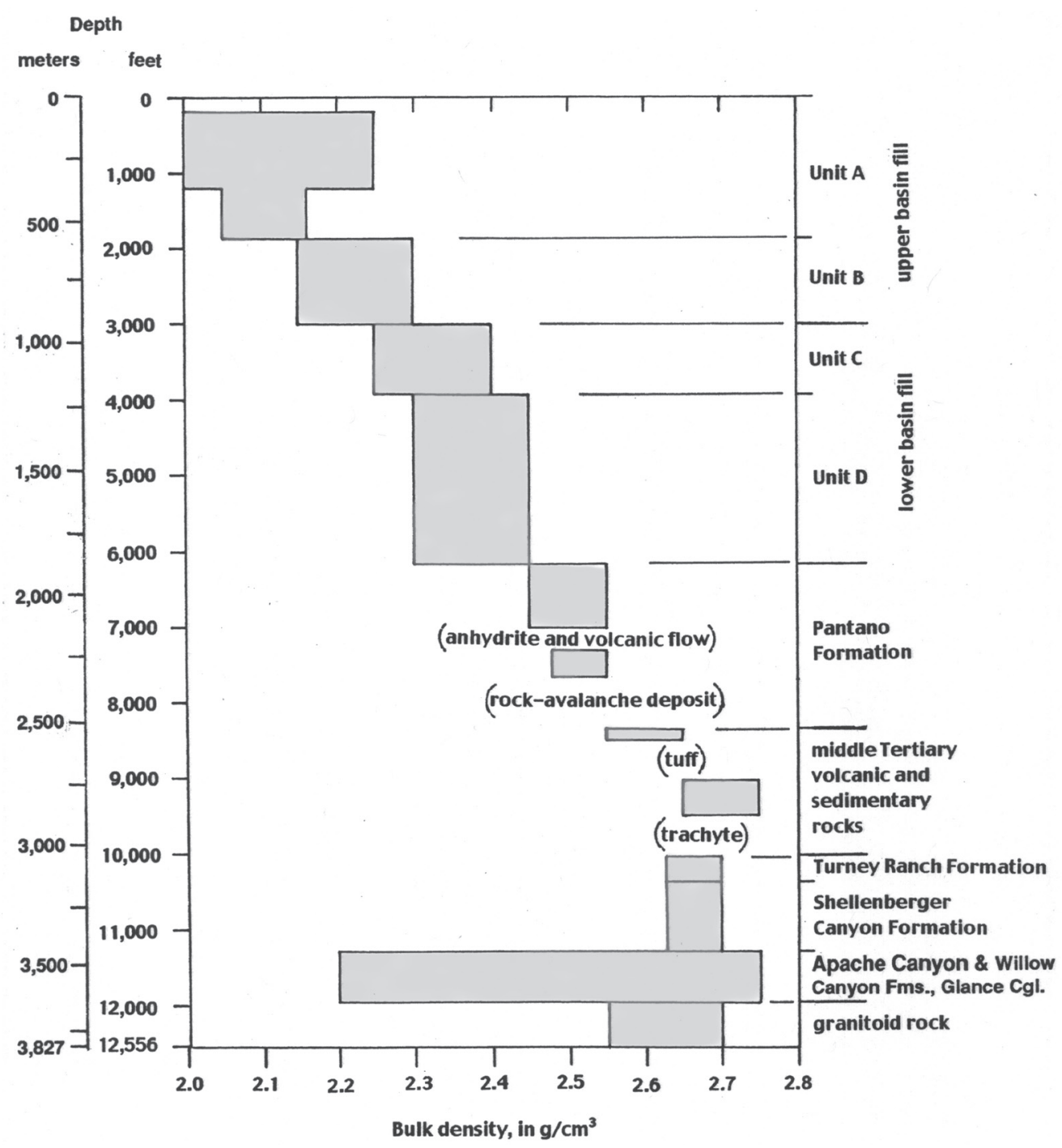

Figure 5. Bulk density of the sedimentary units in the Exxon State (32)-1 well. Boxes represent average high and low bulk density within each sedimentary unit interval. Average bulk densities were estimated visually from the formation density logs (figs. 6-13). Volcanic units are labeled, but their bulk densities are not plotted because they are not age and depth dependent. . 
Table 3. Names and ages (where known) of paired upper and lower basin-fill units in basins of southeastern Arizona and southwestern New Mexico.

\begin{tabular}{|c|c|c|c|}
\hline Basin location & Upper basin-fill unit & Lower basin-fill unit & References \\
\hline $\begin{array}{l}\text { Tucson Basin, } \\
\text { Arizona }\end{array}$ & $\begin{array}{l}\text { Upper Tinaja beds; age } \\
\text { not constrained }\end{array}$ & $\begin{array}{l}\text { Middle Tinaja beds; } \\
\text { age not constrained }\end{array}$ & Anderson, 1987 \\
\hline $\begin{array}{l}\text { Upper Santa Cruz } \\
\text { Basin, Arizona }\end{array}$ & $\begin{array}{l}\text { Unnamed; age not } \\
\text { constrained }\end{array}$ & $\begin{array}{l}\text { Nogales Formation; } \\
\text { middle to upper } \\
\text { Miocene; base is } \\
17.38 \mathrm{Ma} \text { to } 13.23 \mathrm{Ma}\end{array}$ & $\begin{array}{l}\text { Simons, } 1974 ; \text { Houser } \\
\text { and others, this report }\end{array}$ \\
\hline $\begin{array}{l}\text { Upper San Pedro } \\
\text { Basin, Arizona } \\
\text { (south of Narrows) }\end{array}$ & $\begin{array}{l}\text { St. David Formation; } \\
\text { Pliocene and lower } \\
\text { Pleistocene }\end{array}$ & $\begin{array}{l}\text { Unnamed; pre-upper } \\
\text { Pliocene; age not } \\
\text { otherwise constrained }\end{array}$ & $\begin{array}{l}\text { Brown and others, } \\
\text { 1966; Gray, 1967; } \\
\text { Johnson and others, } \\
1975\end{array}$ \\
\hline $\begin{array}{l}\text { Lower San Pedro } \\
\text { Basin, Arizona (north } \\
\text { of Narrows) }\end{array}$ & Not present? & $\begin{array}{l}\text { Quiburis Formation; } \\
\text { middle to upper } \\
\text { Miocene; older than } \\
5.35 \mathrm{Ma} \text { ? }\end{array}$ & $\begin{array}{l}\text { Smith,1967; } \\
\text { Scarborough, 1975; } \\
\text { Lindsay and others, } \\
\text { 1984; Reynolds and } \\
\text { others, } 1986\end{array}$ \\
\hline $\begin{array}{l}\text { Safford Basin, } \\
\text { Arizona }\end{array}$ & $\begin{array}{l}111 \text { Ranch beds; } \\
\text { Pliocene }\end{array}$ & $\begin{array}{l}\text { Midnight Canyon } \\
\text { Conglomerate; middle } \\
\text { to upper Miocene; } \\
\text { base probably younger } \\
\text { than } 17 \mathrm{Ma}\end{array}$ & $\begin{array}{l}\text { Richter and others, } \\
\text { 1983; Galusha and } \\
\text { others, 1984; Houser } \\
\text { and others, 1985; } \\
\text { Kruger and others, } \\
1995\end{array}$ \\
\hline $\begin{array}{l}\text { Alma Basin, New } \\
\text { Mexico and Arizona }\end{array}$ & $\begin{array}{l}\text { Alma beds; younger } \\
\text { than } 5.6 \mathrm{Ma}\end{array}$ & $\begin{array}{l}\text { Keller Canyon } \\
\text { conglomerate; middle } \\
\text { to upper Miocene; } \\
\text { younger than } 18.7 \mathrm{Ma} \\
\text { to older than } 10.4 \mathrm{Ma}\end{array}$ & $\begin{array}{l}\text { Houser, 1987, 1994, } \\
\text { and unpublished data }\end{array}$ \\
\hline $\begin{array}{l}\text { Sonoita Basin, } \\
\text { Arizona }\end{array}$ & $\begin{array}{l}\text { Undeformed upper basin } \\
\text { fill; younger than } 5.8 \mathrm{Ma}\end{array}$ & $\begin{array}{l}\text { Deformed lower basin } \\
\text { fill; older than } 5.8 \mathrm{Ma}\end{array}$ & $\begin{array}{l}\text { Menges and } \\
\text { McFadden, } 1981\end{array}$ \\
\hline
\end{tabular}

\section{Fort Lowell Formation}

Davidson (1973, p. E25-E30) defined the lower to middle Pleistocene Fort Lowell Formation on the basis of cuttings and core from a well (the type section) located in the northern part of the Tucson Basin, just south of exposures of lower basinfill conglomerates in the Catalina Foothills. Because the well is so close to the contact between upper basin-fill and lower basin-fill rocks, and to the edge of the basin, it probably is not representative of basin-wide sedimentation. In fact, Davidson stated (1973, p. E27) that the base of the formation is difficult or impossible to identify in the subsurface data of wells farther out in the basin.

Davidson (1973, plate 2, cross section E-E') estimated the thickness of the Fort Lowell Formation to be 90 to $120 \mathrm{~m}$ (about 300 to $400 \mathrm{ft}$ ) and showed the base of the formation at a depth of $107 \mathrm{~m}(350 \mathrm{ft})$ in a well near Exxon State (32)1; later, Anderson (1987, plate 1, cross section F-F') showed the basal contact of the Fort Lowell at the same depth $(107 \mathrm{~m}$ [350 ft]) in the Exxon well. However, study of the cuttings and geophysical logs of the Exxon well does not indicate any significant change in the sedimentary rocks near the depth of $107 \mathrm{~m} \mathrm{(350} \mathrm{ft)} \mathrm{or,} \mathrm{in} \mathrm{fact,} \mathrm{at} \mathrm{any} \mathrm{depth} \mathrm{above} \mathrm{a} \mathrm{major} \mathrm{facies}$ change at $341 \mathrm{~m}(1,120 \mathrm{ft})$ in stratigraphic Unit A (figs. 4, 6). That facies change, which marks the base of the Cienega Creek alluvial-fan deposit (see sections on "Geologic Setting" above and "Stratigraphic Unit A" below), may prove to be recognizable in well data throughout much of the basin. If so, the Cienega Creek alluvial-fan deposit will be a more useful and identifiable stratigraphic unit than the Fort Lowell Formation.

\section{Tinaja Beds}

Davidson (1973, p. E20-E25) applied the informal name Tinaja beds (separated into upper and lower) to basin-fill sedimentary rocks in the Tucson Basin underlying the Pleistocene(?) Fort Lowell Formation and overlying the 24.9Ma Pantano Formation (Shafiqullah and others, 1978). In Davidson's usage, the Tinaja beds span all of Pliocene and Miocene time. We consider this to be too long a time period 


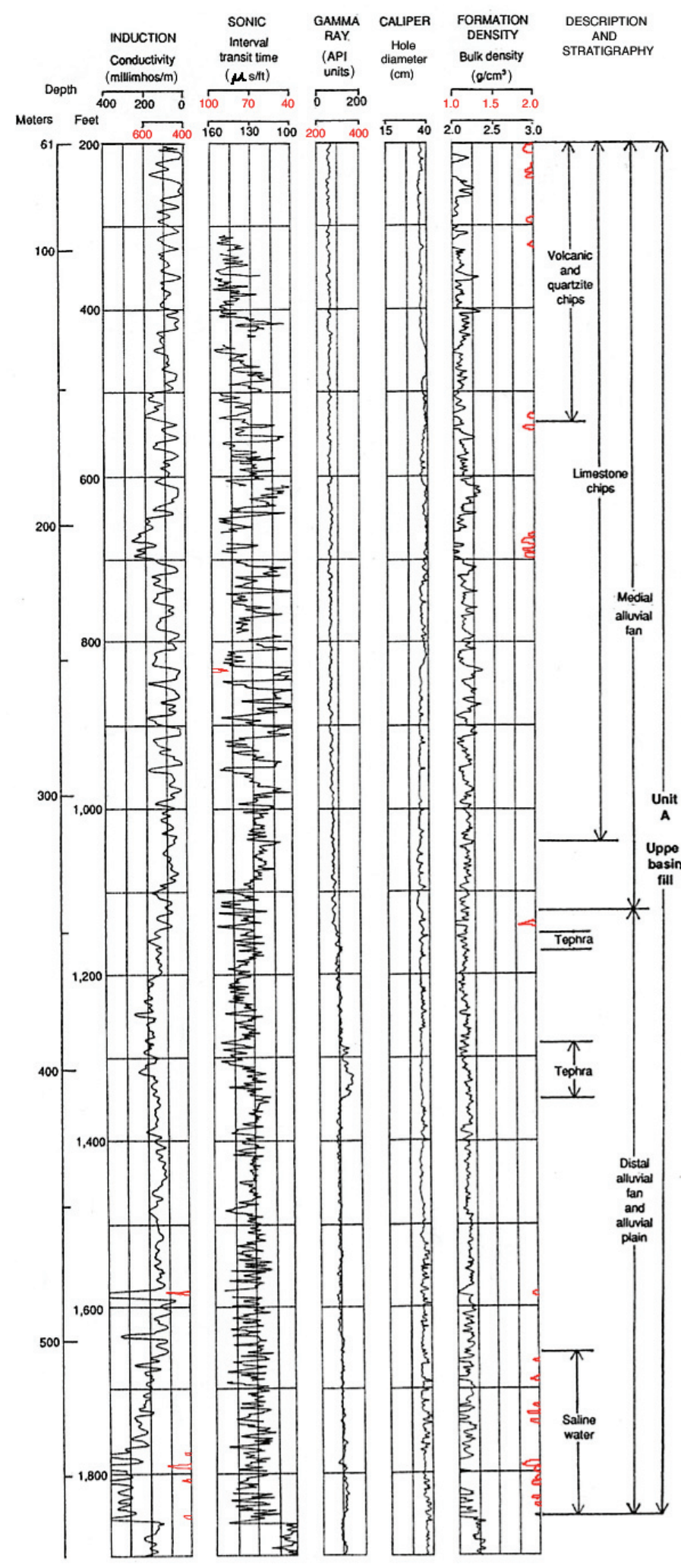

Figure 6. Geophysical logs of Unit A, Upper basin-fill deposits, in the Exxon State (32)-1 well. for the term to be very useful as a stratigraphic designation. In particular, Davidson included both upper and lower basinfill units in the upper Tinaja beds and thus made a single unit of sedimentary rock packages that are separated by a hiatus and were deposited under different tectonic conditions (table 3). Anderson (1987, p. 10-12) modified Davidson's terminology by separating the Tinaja beds into three subunits (upper, middle, and lower) and correlated the middle Tinaja with the Nogales Formation and with the lower basin fill of Menges and McFadden (1981) as shown in table 3. However, Anderson (1987) assigned gypsiferous clayey silt in the central part of the Tucson Basin to the middle Tinaja beds. In our interpretation of the stratigraphy of the Exxon well, the gypsiferous clayey silt is not lower basin fill; it is a playa facies at the top of Unit B of the upper basin fill. Thus, in Davidson's usage the Tinaja beds span too long a period of time, and in Anderson's usage the part of the unit correlated with lower basin fill (middle Tinaja beds) was defined as containing sediments that, on close inspection, turn out to be upper basin fill.

Perhaps the chief problem with use of the term Tinaja beds is the age of the unit at its type locality. Cooper (1973) originally used the name "formation of Tinaja Peak" for interbedded andesitic to dacitic volcanic and volcaniclastic rocks of a small eruptive center on the southeast side of the Sierrita Mountains. On the basis of Cooper's early unpublished mapping, Davidson apparently thought the volcaniclastic conglomerate was younger than the Pantano and could be traced northward into the subsurface of the Tucson Basin. However, Cooper's published map (1973) gives an age of 23.7 Ma for andesite at the base of the formation of Tinaja Peak, and we have obtained an ${ }^{40} \mathrm{Ar} /{ }^{39} \mathrm{Ar}$ age of $24.70 \pm 0.19$ Ma on sanidine crystals from an ash-fall tuff bed in the thick tuffaceous conglomerate unit at the top of the formation of Tinaja Peak (table 2; fig. 15 ). These dates demonstrate that the overlying conglomerate is similar in age to the volcanic rocks of the eruptive center (late Oligocene to early Miocene) and that both are about the same age as the Pantano Formation (24.9 Ma). Therefore, it is inappropriate to apply the term Tinaja beds to basin-fill units that probably are no older than $17 \mathrm{Ma}$.

\section{DESCRIPTIONS OF STRATIGRAPHIC UNITS}

\section{Upper Basin-Fill Deposits, 0-908 m $(0-2,980 \mathrm{ft})$}

The sedimentary rocks here termed upper basin fill in Exxon State (32)-1 can be separated into two units that reflect, from younger to older, (A) medial alluvial-fan, distal alluvial-fan, and alluvial-plain facies, and (B) playa, playa margin, and distal alluvial-fan facies (figs. 4, 6, 7). We des- 


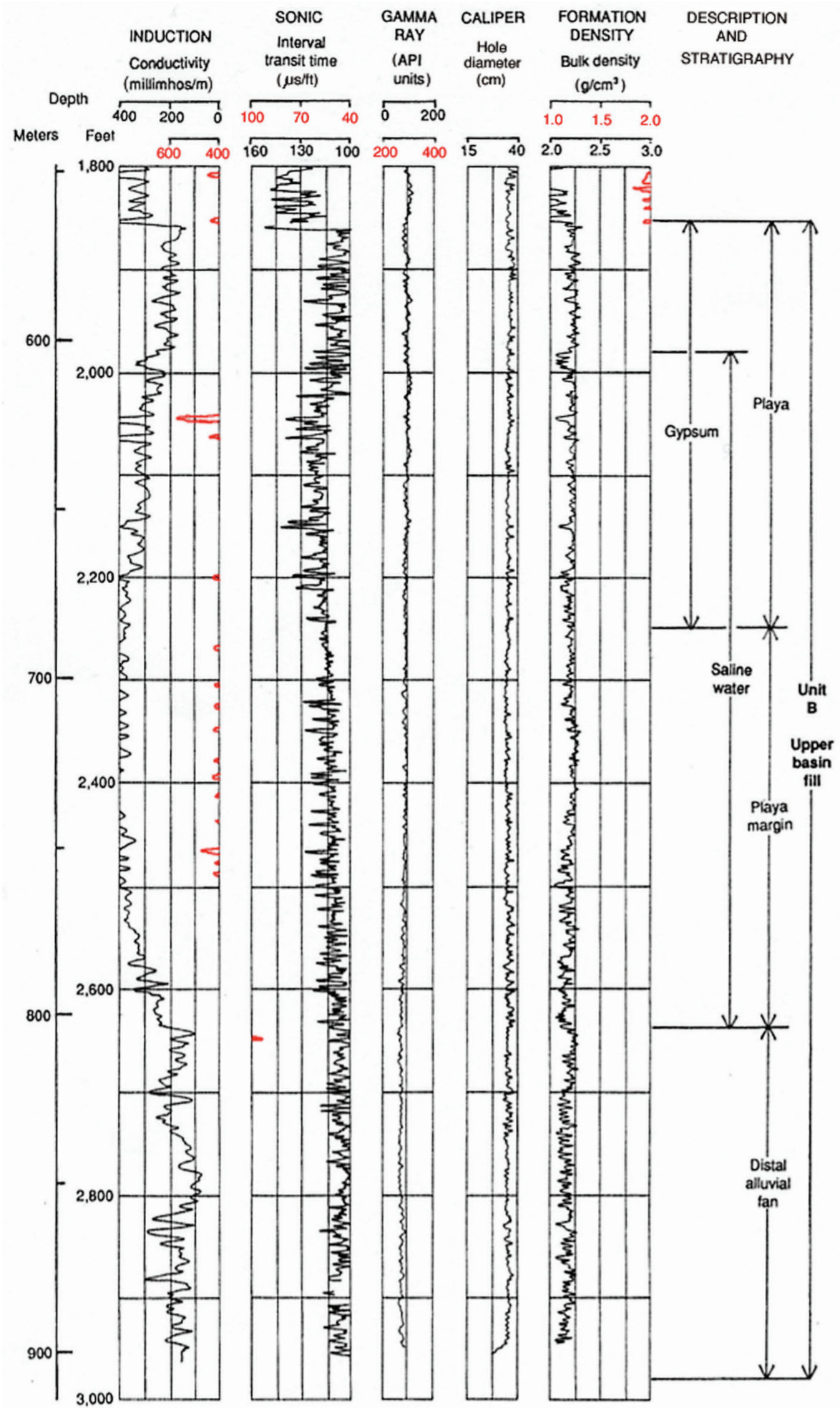

Figure 7. Geophysical logs of Unit B, Upper basin-fill deposits, in the Exxon State (32)-1 well. 


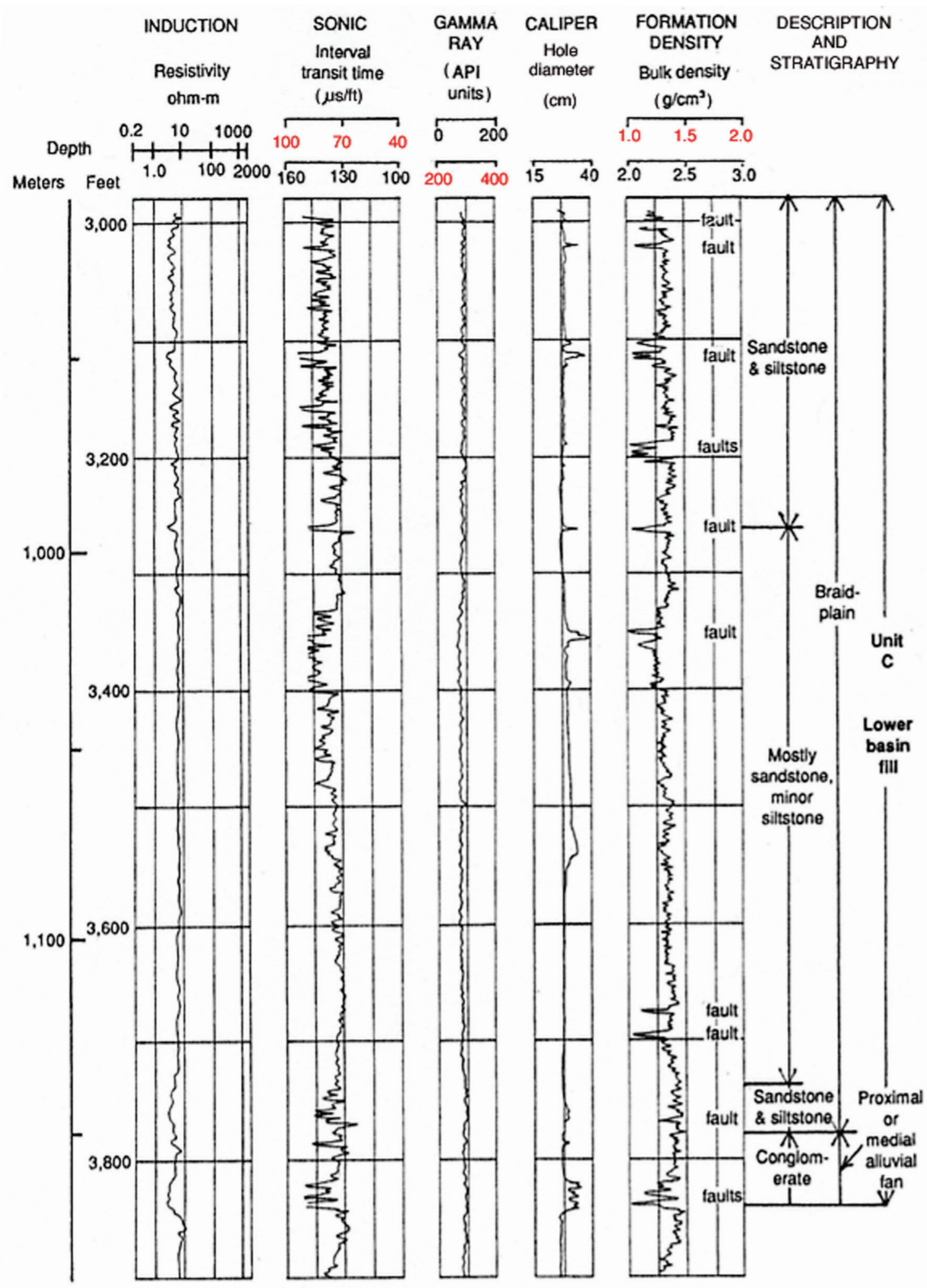

Figure 8. Geophysical logs of Unit C, Lower basin-fill deposits, in the Exxon State (32)-1 well. 
ignate these as units A and B to avoid confusion with the numerical terminology used by Pashley (1966) and Eberly and Stanley (1978) to designate stratigraphic units in the basin. Similarly, we subdivide the lower basin-fill sequence into units $\mathrm{C}$ and D (figs. 8 and 9).

\section{Stratigraphic Unit A, 0-566 m (0-1,856 ft) - Lower Pleistocene(?) and Upper Pliocene(?)}

There are no cuttings for the upper $70 \mathrm{~m}(230 \mathrm{ft})$ of Exxon State (32)-1, and no geophysical logs were run in the upper 61 $\mathrm{m}(200 \mathrm{ft})$. However, drill cuttings and logs of nearby water wells provide adequate coverage of this interval. In addition, the Quaternary and upper Tertiary geologic map of the Tucson $1^{\circ} \times 2^{\circ}$ quadrangle (Pearthree and others, 1988) shows that basin-fill deposits are exposed at the well site. Satellite images (fig. 2) indicate that these deposits are part of a slightly dissected low-gradient alluvial fan derived from eastern source areas in Davidson Canyon, Cienega Gap, and the Cienega Creek drainage basins (see section on "Geologic Setting" above). The fan extended from the mouth of Cienega Creek westward $25 \mathrm{~km}$ to the Santa Cruz River and northward 20 $\mathrm{km}$ to the present outskirts of Tucson. The location of Exxon State (32)-1 near the middle of the fan surface suggests that alluvial-fan deposits are likely to be encountered in the well, and are likely to be of medial alluvial-fan facies. The age of the uppermost basin-fill deposits at the well site probably is early Pleistocene or late Pliocene (Pearthree and others, 1988).

The upper half of Unit A consists of these fan deposits. Unit $\mathrm{A}$ is a fluvial unit more than $566 \mathrm{~m}(1,856 \mathrm{ft})$ thick that represents (1) medial alluvial-fan facies (0-341 m [0-1,120 ft]) overlying and grading to (2) distal alluvial-fan and alluvialplain facies (341-566 m [1,120-1,856 ft]). Unit A consists chiefly of interbedded sandy conglomerate, pebbly sandstone, sandy siltstone, and unconsolidated calcareous sandy mud (fig. 4).

The cuttings indicate that conglomerate clasts in the upper part of Unit A (70-341 m [230-1,120 ft]) consist of limestone, quartz, and both unaltered and chloritized granitoid lithics. Absence of gneissic granitoid chips in the cuttings indicates that the source area did not include the mylonitic granitoid terrane of the Rincon and Santa Catalina Mountains in the foot wall of the Catalina detachment fault. Chips of quartzite and intermediate composition volcanics are also present, but only down to $165 \mathrm{~m}(540 \mathrm{ft})$. The cuttings contain fragments of slightly indurated, calcareous micaceous siltstone and sandstone that presumably are interbedded with the conglomerate. Sand-size mineral fragments in the cuttings include quartz, muscovite, chlorite, epidote, and magnetite. The average dry color of the cuttings is pale yellowish-brown (10 YR 6/2).

Figure 5 and the density log (fig. 6) show that the bulk density of sediment in the upper part of Unit A varies considerably. The maximum range is from 1.85 to $2.45 \mathrm{~g} / \mathrm{cm}^{3}$, and the average is about $2.1 \mathrm{~g} / \mathrm{cm}^{3}$. The higher density peaks probably correspond to calcite-cemented gravel beds as much

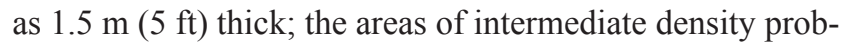

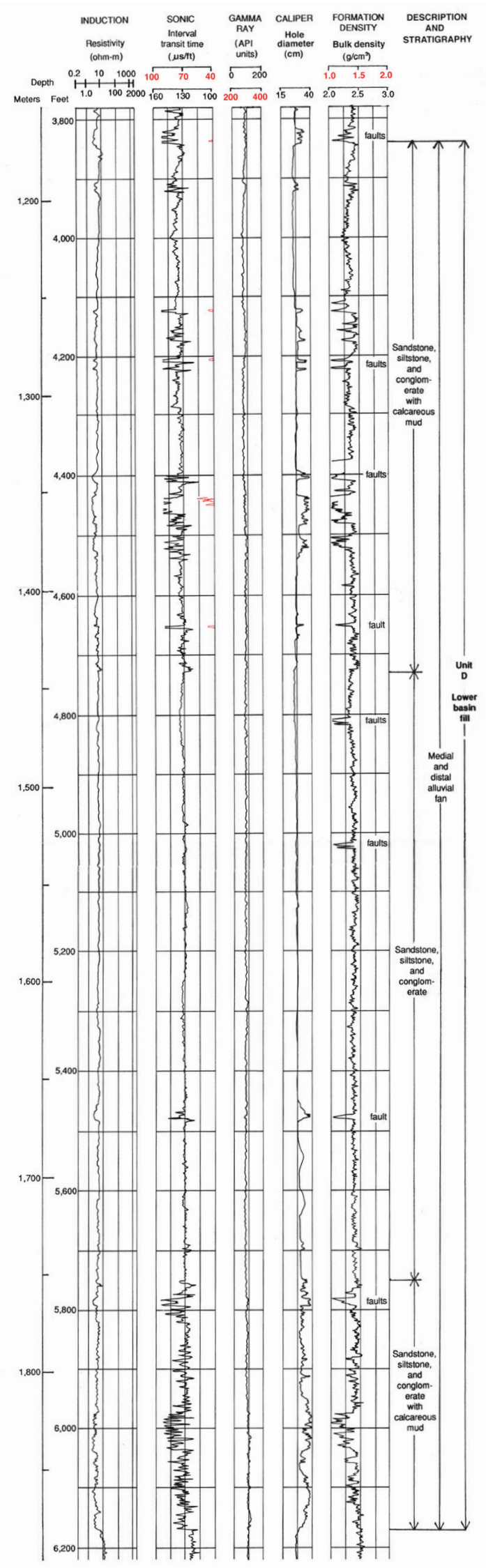

Figure 9. Geophysical logs of Unit D, Lower basin-fill deposits, in the Exxon State (32)-1 well. 
ably correspond to slightly indurated, calcareous micaceous siltstone and sandstone in beds $1.5-3 \mathrm{~m} \mathrm{(5-10} \mathrm{ft)} \mathrm{thick} \mathrm{inter-}$ bedded with the gravel; and the low density areas correspond to unconsolidated, very calcareous sandy mud. The sonic log, induction electrical log, gamma ray log, and caliper log (fig. 6) also demonstrate the relatively thin bedded, chiefly poorly consolidated, but highly variable nature of the upper part of Unit A.

The contact of the upper and lower parts of Unit A near $341 \mathrm{~m}(1,120 \mathrm{ft})$ is gradational and coincides with a downward decrease in thin, relatively dense, moderately well cemented conglomerate beds accompanied by an increase in sandy lime mud. This change in lithology results in an overall decrease in the variability of the bulk density for the lower part of Unit $A$ as shown on figures 5 and 6 . The contact between the upper and lower parts of Unit A is further marked by the absence of limestone lithic chips below about $317 \mathrm{~m}(1,040 \mathrm{ft})$, and a color change from pale yellowish-brown (10 YR 6/2) to light brown (5 YR 6/4) at $341 \mathrm{~m}(1,120 \mathrm{ft})$. The contact was chosen as $341 \mathrm{~m}(1,120 \mathrm{ft})$ because the color change of the cuttings is fairly abrupt at this depth. The next color change is at $503 \mathrm{~m}$ $(1,650 \mathrm{ft})$ from light brown to pale red (5 R 6/2), following a trend to more reddish color with increasing age that is typical of upper Cenozoic continental sediments in the southern Basin and Range Province.

The color change at $341 \mathrm{~m}(1,120 \mathrm{ft})$ and the influx of limestone clasts into the basin fill at $317 \mathrm{~m}(1,040 \mathrm{ft})$ probably record the beginning of deposition of the alluvial fan that now occupies much of the surface of the Tucson Basin. The fan head is at Cienega Gap (fig. 1), and the first Paleozoic limestone clasts to be deposited may have come from exposures in the hanging wall of the Catalina detachment fault on the north side of Cienega Gap. With continued erosion, limestone clasts could have been transported northward by Cienega Creek and Davidson Creek from the Whetstone and Empire Mountains. The influx of quartzite and volcanic clasts at $165 \mathrm{~m}(540 \mathrm{ft})$ suggests that Upper Cretaceous sedimentary and volcanic rocks were being eroded from Davidson Canyon and that Bisbee Group conglomerates containing quartzite clasts were being eroded from both Davidson Canyon and Cienega Creek Valley.

Field relations indicate that Cienega Gap, Davidson Canyon, and Cienega Creek Valley were sediment-filled basins when deposition of the alluvial fan began. Nearly all of Cienega Gap and Davidson Canyon have been exhumed, and basin-fill alluvium has been eroded from the lower part of Cienega Creek Valley. The event, whether climatic or tectonic, that triggered the erosion of basin fill from these three areas has not been identified and is the subject of ongoing studies.

The lower part of Unit A extends from 341 to $565 \mathrm{~m}$ $(1,120 \mathrm{ft}$ to $1,856 \mathrm{ft})$ and has a thickness of $224 \mathrm{~m}(736 \mathrm{ft})$. It consists chiefly of light brown (5 YR 6/4) unconsolidated, sandy lime mud and somewhat better indurated, very finegrained micaceous sandstone. Soft, light greenish-gray (5 GY 8/1) lime mudstone is present as a minor constituent. The only lithic fragments present are granitoid lithics and quartz; the only minerals are quartz, feldspar, muscovite, biotite, and chlorite. The granitoid lithics are actually abraded quartz fragments that contain bits of mica or other small mafic mineral inclusions, implying that the source area for the granitoid clasts was either remote from the depositional area or was a mature weathered terrane. Clusters of 1-mm-long calcite crystals are common. The caliper log of figure 6 shows numerous washouts and the sediment is termed "very soft gummy" on the mud $\log$.

Two intervals near the top of the lower part of Unit A (350-358 $\mathrm{m}$ and 392-411 $\mathrm{m}[1,150-1,175 \mathrm{ft}$ and 1,285-1,350 $\mathrm{ft}]$ ) show significant increases in radiation on the gamma ray $\log$, from a background 80 to 100 API units for sediment above and below the intervals to as much as 160 API units for sediment within the intervals. The increased radiation can be attributed to volcanic ash beds (tephra) deposited with the sediment (fig. 6). The shape of the curves on the gamma ray log suggests that a few individual beds of relatively clean ash as much as $1.5 \mathrm{~m}(5 \mathrm{ft})$ thick occur within zones of reworked ash and sediment. White grains consisting of aggregates of clay and glass shards are present in cuttings from this interval, lending credence to our interpretation of the gamma ray log. The presence of interbedded tephra indicates a low-energy depositional environment and supports our interpretation that the lower part of Unit A consists of sediments of distal alluvial-fan and alluvial-plain facies. Davidson (1973, p. E23) reported a 1-m-thick (3-ft) bed of silty tuff that was cored in a well located about $4 \mathrm{~km}(2.5$ $\mathrm{mi})$ northwest of the Exxon well. The elevation of the cored tuff is $361 \mathrm{~m}(1,185 \mathrm{ft}), 104 \mathrm{~m}$ and $165 \mathrm{~m}$ ( $340 \mathrm{ft}$ and $540 \mathrm{ft})$ lower than the two tuffaceous intervals in the Exxon well. This relationship suggests that the tephra beds are probably discontinuous and lenticular.

The contact of the lower part of Unit A with Unit B is sharp and is evidenced by a downward increase in bulk density and decreases in interval transist time and in conductivity (figs. $5,6,7$ ). The higher bulk density and lower interval transit time of Unit B are important because they indicate that a significant amount of time must have elapsed between the deposition of Units B and A, long enough for diagenesis and compaction to increase the bulk density from $2.05-2.28 \mathrm{~g} / \mathrm{cm}^{3}$ to $2.15-2.30 \mathrm{~g} / \mathrm{cm}^{3}$.

The reason for the difference in conductivity of the two units is more difficult to interpret, but may be related to the presence of saline connate water and to variation in porosity associated with diagenesis. Figures 6 and 7 show that the conductivity of the alluvial-plain sediments in the lower part of Unit A increases from about 120 millimhos/m to $350 \mathrm{mil}-$ limhos/m in the 60-m-thick (200-ft) interval above the contact with the gypsiferous playa deposit of Unit B. At the contact, the conductivity decreases abruptly to about 160 millimhos/ $\mathrm{m}$, then gradually increases downhole throughout the playa deposit to about 400 millimhos $/ \mathrm{m}$ in the underlying playamargin deposit. The conductivity again begins to decrease near the bottom of the playa-margin deposit and is about 100 - 
200 millimhos/m in the underlying distal alluvial-fan deposit. We suggest that the observed increases in conductivity in the alluvial-plain and playa-margin deposits are caused by the presence of connate saline water associated with the playa, which has had limited circulation through the more permeable sediments above and below the playa deposits.

\section{Stratigraphic Unit B, 566-908 m (1,856-2,980 ft)- Lower(?) Pliocene to Upper Miocene(?)}

Unit B extends from 566 to $908 \mathrm{~m}$ (1,856 to 2,980 ft) and has a thickness of $343 \mathrm{~m}(1,124 \mathrm{ft})$. The unit can be divided into three parts (figs. 4, 7): (1) gypsiferous sandy lime mud between 566 and $686 \mathrm{~m}$ (1,856-2,250 ft), (2) sandy lime mud with sparse gypsum from 686 to $805 \mathrm{~m}$ (2,250-2,640 ft), and (3) from 805 to $908 \mathrm{~m}(2,640-2,980 \mathrm{ft})$, sandy lime mud and poorly indurated muddy sandstone with minor pebble conglomerate beds. The three-part sequence is inferred to represent a 120-m-thick (394-ft) gypsiferous muddy playa deposit overlying $119 \mathrm{~m}$ (390 ft) of playa-

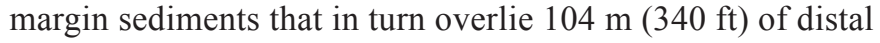
alluvial-fan sediments.

The logs and cuttings indicate that the playa and playamargin deposits constitute fairly uniform, poorly consolidated sediment sequences containing lime mud and very fine- to medium-grained sand (figs. 4, 7). The distal alluvialfan deposits consist of sandy lime mud, increasing amounts (downward) of sandstone and slightly indurated pale-red calcareous micaceous siltstone, and a pebble conglomerate interval from about 841 to $856 \mathrm{~m}(2,760-2,810 \mathrm{ft})$. As in the fine-grained sediments in the lower part of Unit A, the only lithic fragments in Unit B are quartz and abraded granitoid lithics, indicative of a distant or deeply weathered source terrane.

We were not able to place the contact between Unit B (upper basin fill) and Unit C (lower basin fill) precisely because the bottom of the second casing was set at $912 \mathrm{~m}$ $(2,992 \mathrm{ft})$, very close to the contact, and because geophysical logs were not run between 899 and $912 \mathrm{~m} \mathrm{(2,950} \mathrm{and}$ $2,992 \mathrm{ft}$ ). Based on cuttings from this interval, we place the contact at $908 \mathrm{~m}(2,980 \mathrm{ft})$, which corresponds to the base of the muddy gypsiferous sediment of Unit B. Overall, Unit $\mathrm{C}$ of the lower basin fill is slightly coarser grained than Unit $\mathrm{B}$ of the upper basin fill and is better consolidated and less calcareous. The better consolidation is shown by comparison of the bulk density on figure 5 and on the density logs (figs. $7,8)$. The bulk density of the lower $213 \mathrm{~m}(700 \mathrm{ft})$ of Unit $\mathrm{B}$ is 2.10 to $2.25 \mathrm{~g} / \mathrm{cm}^{3}$, whereas the bulk density of lower basin-fill sediments (Units C and D) is significantly higher, typically 2.25 to $2.45 \mathrm{~g} / \mathrm{cm}^{3}$. The difference in consolidation apparently was immediately obvious to the drillers because

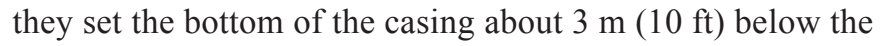
contact of the two units, thus sealing off the less consolidated upper basin-fill rocks so that they would not be continually washing out as drilling progressed.

\section{Lower Basin-Fill Deposits, 908-1,881 m (2,980- $6,170 \mathrm{ft}$ )}

The lower basin-fill deposits, in addition to being better consolidated than the upper basin fill, are more deformed, as indicated by numerous faults identified on the geophysical logs, particularly on the density and caliper logs (figs. 7, 8). The lower basin fill consists of two members, both fluvial, designated Units C and D.

\section{Stratigraphic Unit C, 908-1,170 m (2,980-3,840 $\mathrm{ft}$-_Upper(?) Miocene(?)}

Unit $\mathrm{C}$ is a relatively fine-grained fluvial deposit about $262 \mathrm{~m}(860 \mathrm{ft})$ thick that consists of the following downhole sediment sequence: (1) interbedded sandstone and silt-

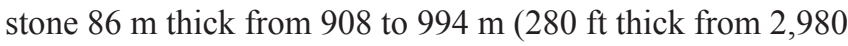
to $3,260 \mathrm{ft}),(2)$ mostly sandstone with minor siltstone $146 \mathrm{~m}$ thick from 994 to $1,140 \mathrm{~m}$ (480 ft thick from 3,260 to 3,740 $\mathrm{ft}),(3)$ interbedded sandstone and siltstone $12 \mathrm{~m}$ thick from 1,140 to $1,152 \mathrm{~m}$ (40 ft thick from 3,740 to 3,780 ft), and (4) conglomerate $18 \mathrm{~m}$ thick from 1,152 to $1,170 \mathrm{~m} \mathrm{(60} \mathrm{ft} \mathrm{thick}$ from 3,780 to $3,840 \mathrm{ft}$ ).

Cuttings from the two sandstone and siltstone intervals contain abundant chips of pale red (5 R 6/2) to grayish-orangepink (5 YR 7/2) moderately well indurated, slightly calcareous, micaceous sandy siltstone and very calcareous, micaceous muddy sandstone. The sandy siltstone lithology is the same as in Unit A except that it is better consolidated and less calcareous. The cuttings consist of abundant fragments of granitoid and quartz clasts, and rare fragments of volcanic and limestone clasts. The mineral grains are quartz, feldspar, muscovite, biotite, chlorite, and magnetite. Some of the granitoid lithics are rounded quartz with included micas or mafic minerals, as in Units A and B, implying a source area that was distant or was a weathered terrane of low relief. However, the granitoid lithics also include subangular polycrystalline fragments composed of quartz, feldspar, micas, and mafics, implying a closer source. Rare malachite crusts and pyrite crystals suggest the presence of mineralized rocks in the source area. Small amounts of gypsum and anhydrite are present throughout Unit C.

The depositional environment of Unit $\mathrm{C}$ is interpreted for the most part to be a sandy braidplain. This is indicated by the relatively good separation of sandstone and siltstone into well defined interbeds rather than the muddy, poorly sorted mix of the alluvial-plain and playa facies of Units A and B and by the occurrence of only minor amounts of gypsum and anhydrite.

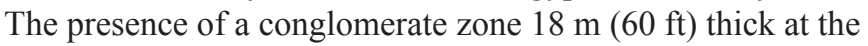
base of Unit $\mathrm{C}$ suggests that a significant unconformity exists between Unit $\mathrm{C}$ and the underlying Unit D. Lithic fragments and mineral grains in the conglomerate are the same as elsewhere in Unit C, except for uncommon fragments of quartzite that resemble Precambrian or Paleozoic lithologies of the region. 
Faults are numerous throughout Unit $\mathrm{C}$, as shown by thin, sharply defined intervals of decreased bulk density on the density log of figure 8 . Ten individual faults and zones of faulting are recognized, in contrast to Units A and B, which show no identifiable evidence of faulting. The density log indicates that the intervals of crushed rock marking individual

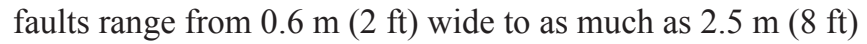
wide and that zones of faulting are as wide as $8.5 \mathrm{~m}(28 \mathrm{ft})$. It is important to realize that these widths of crushed rock are maximum values and may be more a function of the angle of the fault than of the amount of deformation associated with it. In outcrop most faults observed in lower basin-fill rocks are high-angle faults, which means that a vertical drill hole will penetrate a considerable thickness of brecciated rock bordering the fault plane itself.

The caliper and sonic logs show that most faults correspond to washed-out intervals and increased interval transit time, but a few do not show these characteritics, suggesting that some fault breccias might be recemented. The gamma ray log shows no pronounced increases in gamma radiation corresponding to faults, suggesting that the brecciated fault gouge contains little or no clay.

The thickness of Unit C penetrated in the well (262 m [860 ft]) may not be an accurate measure of its true thickness for several reasons: (1) zones of faulting at both the top and bottom of the unit could have cut out some of the section; (2) faults within the unit may have repeated or cut out part of the section; and (3) outcrops of faulted lower basin-fill units are commonly tilted $10^{\circ}$ to $15^{\circ}$; such dips would increase the apparent thickness in a vertical drill hole.

\section{Stratigraphic Unit D, 1,170-1,880 m (3,840-6,170 $\mathrm{ft}$ ) — Upper(?) and Middle Miocene}

Unit D of the lower basin fill is $710 \mathrm{~m}$ thick $(2,330 \mathrm{ft})$, pale red in color ( $5 \mathrm{R} 6 / 2$ ), and consists of calcareous mud, siltstone, sandstone, and conglomerate that vary from poorly to moderately indurated over short intervals. The depositional setting is inferred to be medial to distal alluvial fan, similar to the upper part of Unit A. Lithics in the cuttings consist of abundant granite and quartz and rare quartzite, limestone, and volcanics. Granitoid lithics are of two types(1) abraded quartz fragments containing bits of mica and mafic inclusions and (2) angular polycrystalline fragments of quartz and feldspar with micas and mafic minerals - indicating both distant and nearby sources for the granitoid clasts. The mineral grains are quartz, feldspar, muscovite, biotite, and chlorite. Chips of pale red (5 R 6/2) well indurated, noncalcareous, micaceous sandy siltstone and calcareous, micaceous muddy sandstone are abundant. Gypsum is present, but uncommon, between 1,170 and 1,344 $\mathrm{m}(3,840$ and 4,410 ft).

The geophysical logs (fig. 9) indicate that the sequence can be separated into three parts on the basis of degree of consolidation. The upper $271 \mathrm{~m}$ (890 ft) of Unit D, from 1,170 to $1,441 \mathrm{~m}(3,840$ to $4,730 \mathrm{ft})$, and the lower $128 \mathrm{~m}(420 \mathrm{ft})$ from
1,753 to $1,880 \mathrm{~m}$ (from 5,750 to $6,170 \mathrm{ft}$ ), show extreme variations in density, interval transit time, and resistivity, and the caliper log shows that the well diameter was greatly enlarged by washouts in these two intervals. The highly variable degree of consolidation is probably caused by the presence of numerous thin beds of unconsolidated calcareous mud interbedded throughout the more typical, moderately well consolidated siltstone, sandstone, and conglomerate beds.

The drill cuttings and the mud log show that the 311m-thick $(1,020-\mathrm{ft})$ middle interval $(1,442$ to $1,753 \mathrm{~m}[4,730$ $5,750 \mathrm{ft}]$ ) contains siltstone, sandstone, and conglomerate similar to the upper and lower intervals, but contains little unconsolidated mud. The paucity of unconsolidated mud is evidenced on the geophysical logs (fig. 9) which show that the middle interval has a much more uniform bulk density (2.3-2.4 g/ $\left.\mathrm{cm}^{3}\right)$, interval transit time (85-100 microseconds/ $\mathrm{ft}$ ), and resistivity (3-5 ohm-m), and, thus, gives a more realistic indication of the typical degree of consolidation to be expected of lower basin-fill deposits at this depth in the basin.

The geophysical logs (fig. 9) show that Unit D is highly faulted, perhaps more so than Unit $\mathrm{C}$. There are four zones of faulting and associated brecciation from $15 \mathrm{~m}(50 \mathrm{ft})$ to more than $30 \mathrm{~m}(100 \mathrm{ft})$ wide, but individual faults are more difficult to identify because of the variable consolidation of Unit D. As with Unit C, the faulting and probable tilting (by analogy to similar age units in outcrop) of Unit D cause the thickness of the unit penetrated in the well to be only an approximation of its true thickness.

The contact between Unit D and the upper conglomerate of the underlying Pantano Formation is sharp, and on the geophysical logs (figs. 9, 10) is characterized by several distinct signatures: (1) an increase in bulk density from about 2.35 to $2.55 \mathrm{~g} / \mathrm{cm}^{3}$ (fig. 5); (2) an increase in resistivity from about 2 to $10 \mathrm{ohm}-\mathrm{m}$; and (3) a decrease in interval transit time from 90 to 80 microseconds/ft. There is, however, only a small change in gamma radiation, which remains at about 100 API units. The washouts and muddy sediment typical of Unit D of the lower basin fill cease abruptly at $1,880 \mathrm{~m}(6,170 \mathrm{ft})$. The presence of abundant volcanic fragments in the Pantano Formation (fig. 4) further serves to differentiate the Pantano from the overlying lower basin-fill, which contains only rare volcanic fragments. The sharpness of the contact, the markedly dissimilar characteristics on the geophysical logs of Unit D and the upper Pantano Formation, and the absence on the logs of sharp peaks that might indicate a fault at the contact, all suggest that the contact is probably an erosional unconformity representing a considerable hiatus.

\section{Pantano Formation, 1,880 -2,516 m $(6,170-8,256 \mathrm{ft})$-Lower Miocene and Upper Oligocene(?)}

In roadcuts, clay quarries, and outcrops in Cienega Gap (fig. 1) — the saddle between the Rincon and Santa Rita 


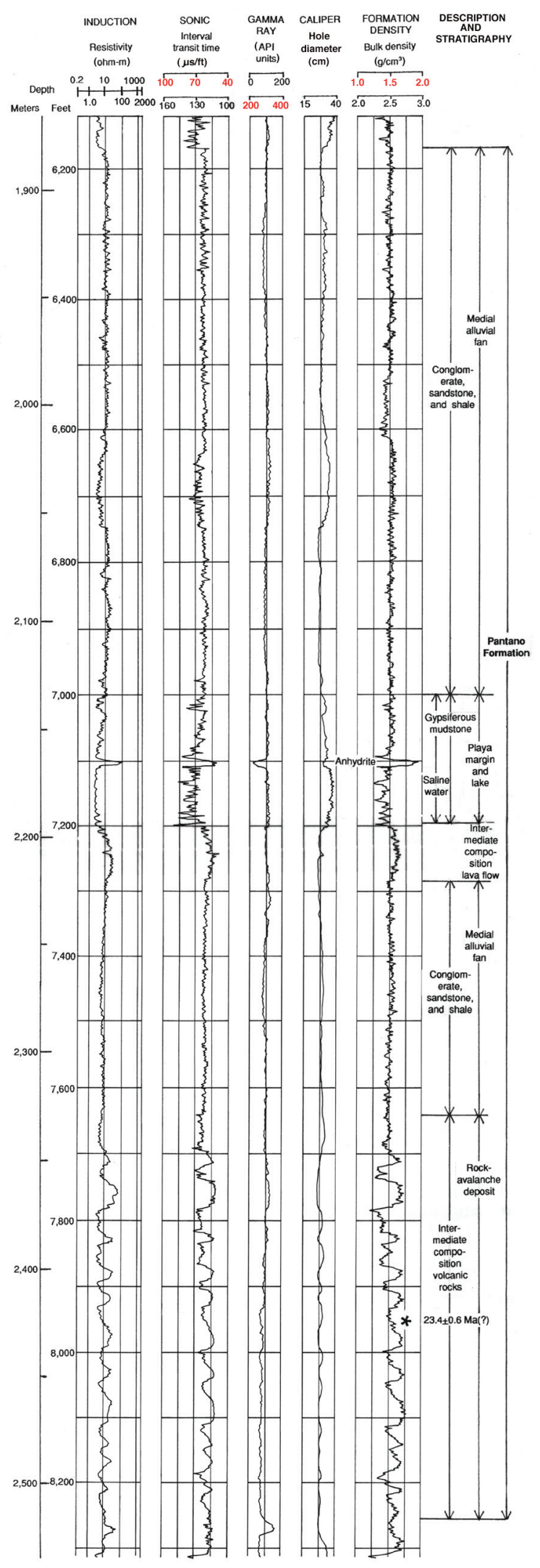

Figure 10. Geophysical logs of the Pantano Formation, in the Exxon State (32)-1 well. Asterisk indicates location of interval of sampled cuttings that gave a whole-rock K-Ar age of 23.4 $\pm 0.6 \mathrm{Ma}$ (Eberly and Stanley, 1978).
Mountains about 17 to $25 \mathrm{~km}$ (10 to $15 \mathrm{mi}$ ) east of the site of the Exxon State (32)-1 well - the Pantano Formation is well exposed and has been described by Brennan (1957), Finnell (1970b), and Balcer (1984). An andesite flow near the middle of the Pantano, exposed where the Southern Pacific Railroad bridge and Pantano Road cross Cienega Creek, has been dated at 24.93 $\pm 2.6 \mathrm{Ma}$ (K-Ar on plagioclase; Shafiqullah and others, 1978). Because the andesite flow has been pervasively chloritized and is cut by numerous jasperoid veins, this date probably should be used with caution. Furthermore, potassium metasomatism associated with the uplift of the Catalina core complex may have affected rocks in the Cienega Gap area, which lies in the hanging wall of the Catalina detachment fault just south of the trace of the fault. Thus, it may be more realistic to bracket the age of the Pantano Formation between about $17 \mathrm{Ma}$ (the earliest date for beginning of basin formation) and somewhat less than $26.91 \pm 0.18 \mathrm{Ma}$, which is the date obtained in this study for the silicic tuff $68 \mathrm{~m}(222 \mathrm{ft})$ downsection from the base of the Pantano (see section on "Silicic Tuff" below).

The Pantano Formation in Exxon State (32)-1 is broadly similar to the formation in surface exposures, in that both (as inferred by our correlation) are syntectonic deposits of alluvial fans, playas, rock avalanches, and volcanic flows in a region of middle Tertiary extension. However, a significant difference that may reflect the local tectonic setting of the two sites at the time of deposition is that in the Exxon well, rock-avalanche deposits occur at the bottom of the Pantano, whereas at Cienega Gap, there is a rock-avalanche deposit at the top.

In Exxon State (32)-1, the 703-m-thick (2,308-ft) interval assigned to the Pantano Formation consists of two parts: (1) a 449-m-thick (1,472-ft) well-consolidated gypsiferous, muddy conglomerate (1,880-2,329m [6,170-7,642 ft]) containing an andesite(?) flow in the lower half; and (2) a 187-m-thick (614-ft) sequence we infer to be a composite rock-avalanche deposit composed chiefly of intermediate-composition volcanic rocks $(2,329-2,516 \mathrm{~m}[7,642-8,256 \mathrm{ft}])$. The overall color of the cuttings darkens gradually from pale red $(5 \mathrm{R} 6 / 2)$ at $1,880 \mathrm{~m}(6,170 \mathrm{ft})$ to grayish-red ( $5 \mathrm{R} \mathrm{4/2})$ by $2,225 \mathrm{~m}(7,300$ $\mathrm{ft})$.

\section{Conglomerate, Mudstone, and Andesite (?) Flow, $1,880-2,329 \mathrm{~m}(6,170-7,642 \mathrm{ft})$}

The geophysical logs (fig. 10) show the Pantano conglomerate and mudstone to be uniformly well consolidated except for a few broad zones of minor washouts and a poorly consolidated interval between 2,133 and 2,194 $\mathrm{m}(7,000-7,197$ $\mathrm{ft}$ ), which contains gypsum and a 3.7-m-thick (12-ft) bed of anhydrite. Few faults are evident on the logs for this part of the Pantano compared to the number interpreted for the overlying lower basin fill. A possible explanation for this may be that fault breccia and gouge has been recemented in the better consolidated Pantano conglomerate so the faults are not obvi- 
ous on the logs. The geophysical logs and the composition of lithics and mineral grains in the cuttings allow the conglomerate, mudstone, and andesite of the Pantano Formation to be described in four parts:

(1) 1,880 to about $2,133 \mathrm{~m}(6,170-7,000 \mathrm{ft})$. -The conglomerate in this interval is inferred to be a medial alluvial-fan deposit. It contains abundant volcanic clasts and common granitoid clasts interbedded with well-consolidated pale-red (5 R 6/2) slightly calcareous to noncalcareous, slightly gypsiferous, micaceous shale and muddy calcareous micaceous sandstone. The bulk density ranges from 2.35 to $2.65 \mathrm{~g} / \mathrm{cm}^{3}$, with an average of about $2.50 \mathrm{~g} / \mathrm{cm}^{3}$ (figs. 5, 10). Lithic clasts consist of angular quartz fragments, quartz with mica and mafic inclusions, granitoid chips of various kinds (unaltered; with red feldspar; pink chloritized; epidotized), abundant gray volcanic chips of probable intermediate composition, and rare limestone chips. Mineral grains in the cuttings consist of muscovite, biotite, chlorite, epidote, and two types of quartz (rounded with frosted or polished surfaces and angular).

(2) About 2,133 to 2,194 $\mathrm{m}(7,000-7,197 \mathrm{ft})$. - This is a poorly consolidated muddy evaporite interval that contains a 3.7-m-thick (12-ft) anhydrite bed between 2,163 and 2,167 $\mathrm{m}(7,098-7,110 \mathrm{ft})$. The depositional environment may have been a transgressive/regressive sequence of distal alluvial fan, playa margin, and short-lived lake. Cuttings in the interval are coated with mud, and the caliper log (fig. 10) shows that the diameter of the well was washed out from $28 \mathrm{~cm}$ to as much as $38 \mathrm{~cm}$ (from 11 to $15 \mathrm{in}$ ). The bulk density is variable, ranging from 2.25 to $2.60 \mathrm{~g} / \mathrm{cm}^{3}$ (the bulk density of the anhydrite bed is $2.90 \mathrm{~g} / \mathrm{cm}^{3}$ ). Lithic and mineral fragments in the cuttings are the same composition as in the overlying better consolidated conglomerate. Fragments of interbedded shale and sandstone include greenish-gray (5 GY 6/1) to light-olive-gray (5 Y 6/1) calcareous micaceous shale in addition to pale-red shale and sandstone.

The cuttings, density log, and sonic log indicate that the grain size, bedding, and consolidation of the sediment vary considerably over short distances in the evaporite interval. The electrical log, however, shows that the resistivity of the part of the interval between 2,158 and 2,188 $\mathrm{m}(7,080-7,180$ $\mathrm{ft}$ ) is fairly constant at about $3 \mathrm{ohm}-\mathrm{m}$ (except for the anhydrite bed, where it is $100 \mathrm{ohm}-\mathrm{m}$ ). This may indicate that the pore space of both fine-grained and coarse-grained lithologies in this interval is filled with saline connate water.

(3) 2,194 to $2,222 \mathrm{~m}(7,197-7,290 \mathrm{ft})$. - This interval contains the densest rock encountered to this level in the well, nearly $2.70 \mathrm{~g} / \mathrm{cm}^{3}$, and is inferred to be a lava flow of intermediate composition. The geophysical logs (fig. 10) show that rock properties in the interval (bulk density, interval transit time, and resistivity) are similar to those of the intermediate volcanic rock in the inferred rock-avalanche deposit below $(2,329-2,516 \mathrm{~m}[7,642-8,256 \mathrm{ft}])$ and of the intermediate-composition volcanic flow between 2,524 and 2,553 $\mathrm{m}(8,282-$ $8,376 \mathrm{ft}$ ). However, cuttings from this interval indicate that it should be a conglomerate of virtually the same composition as the overlying intervals 1 and 2 . Because the geophysical logs are not likely to be in error, it is more likely that the cuttings were not collected from this 28 -m-thick (93-ft) interval or that the cuttings contain a very large amount of contamination. Thus, the 28-m-thick (93-ft) interval is inferred to consist of one or more intermediate-composition lava flows.

The contact between the volcanic flow of interval 3 and the overlying evaporite interval may be a fault. This is suggested by the density and sonic logs, which both show a sharp change at $2,194 \mathrm{~m}(7,197 \mathrm{ft})$. There is probably also a fault or a flow breccia near the middle of the interval at 2,207 $\mathrm{m}$ $(7,242 \mathrm{ft})$, as shown by a sharp increase in interval transit time and decrease in resistivity at this depth.

(4) 2,222 to 2,329 $\mathrm{m}(7,290-7,642 \mathrm{ft})$. - Conglomerate clasts in this interval are mostly volcanic, as in interval 1 of the conglomerate. However, the volcanic clasts are more varied in composition and many are propylitically altered. Granitoid clasts are sparse to rare, as are rounded detrital quartz grains. The interval is still slightly gypsiferous. The overall color of the cuttings has darkened to grayish red (10 R $4 / 2$ ). The bulk density is fairly constant at $2.50 \mathrm{~g} / \mathrm{cm}^{3}$, about the same as in interval 1 but lower than in the overlying intermediate-composition lava flow (interval 3).

\section{Rock-Avalanche Deposit, 2,329-2,516 m (7,642- $8,256 \mathrm{ft}$ )}

Cuttings from this 187 -m-thick (614-ft) interval consist chiefly of intermediate-composition volcanic rocks. Propylitic alteration of the volcanics is uncommonly present and there are rare fragments of copper-bearing minerals. The color of the cuttings varies from grayish red (5 R 4/2) and blackish red ( $5 \mathrm{R} 2 / 2)$, through medium dark gray (N 4), medium light gray (N 6), and brownish gray (5 YR 4/1). Micaceous shale, sandstone, gypsum, and quartz grains are present in amounts of 10 to 50 percent. Because the variation in quantity of these sediment-derived grains does not correlate with variations in rock properties recorded by the geophysical logs (fig. 10), the grains are attributed to contamination from uphole washouts. This implies that a similar amount of the volcanic fragments in the cuttings (10 to 50 percent) are contamination also, probably from volcanic clasts in conglomerates higher in the Pantano Formation.

This interval is inferred to be a rock-avalanche deposit probably composed of intermediate-composition volcanic rocks. This inferrence is based on unique patterns shown by the geophysical logs in this interval (fig. 10) and their likely correspondence with physical properties that might be expected of rock-avalanche bodies. Rock-avalanche bodies have been described by many workers ( for example, Shreve, 1968; Kreiger, 1977; Yarnold and Lombard, 1989; Yarnold, 1993; Beratan, 1998) and are relatively common in upper Oligocene and lower Miocene syntectonic sedimentary rocks in southeastern Arizona (Creasey, 1965; Kreiger, 1977). One of the occurrences described by Yarnold and Lombard (1989) is the Cross Hill rock-avalanche deposit at the top of the Pantano 
Formation in Cienega Gap (fig. 1). Cooper (1973) mapped rock-avalanche deposits (described as monolithologic breccia of landslide origin) within the Helmet Fanglomerate in the northeastern Sierrita Mountains.

Rock-avalanche deposits are very large volume, tabular or lensoid megabreccia bodies, commonly monolithologic, that begin as giant rockfalls and traverse down several kilometers of relatively gentle slopes at high speed. Other than the opinion that water probably is not involved, there is little consensus as to the medium of support that allows for high-speed nonturbulent transport of the megabreccia bodies, while preserving relict stratigraphy within the megabreccia and disturbing the substrate only minimally. Various mechanisms have been proposed by Kent (1966), Shreve (1968), Hsü (1975), and Melosh (1983).

Yarnold and Lombard (1989) compiled a table of sedimentary characteristics used in distinguishing rock-avalanche deposits from four other types of mass-movement deposits in the field. Most of these field characteristics are not useful for this study because well data are one-dimensional. However, the following five characteristics of rock-avalanche megabreccia bodies are important in the context of this report: (1) they are tens to hundreds of meters thick; (2) they are commonly monolithologic and consist of identifiable lithologic units having relict stratigraphy preserved; (3) stratigraphic repitition occurs along shear planes; (4) they are made up of pervasively brecciated fresh rock and, for the most part, the breccia is dense, being composed of a tight mosaic of unrotated angular fragments (crackle breccia) or fragments separated from each other by thin bands of comminuted rock (jigsaw breccia) (Krieger, 1977); and (5) the unconfined tops of some megabreccia bodies consist of rotated clasts (Kreiger, 1977, fig. 13), which would change the character of the brecciation and have the effect of reducing the bulk density of that part of the avalanche body.

The inferred rock-avalanche deposit in Exxon State (32)-1 appears on the geophysical logs (fig. 10) as a sequence of 13 asymmetrical humps with an aggregate thickness of as much as $187 \mathrm{~m}(614 \mathrm{ft})$. However, because the Pantano Formation is a syntectonic deposit, it is very likely tilted and, choosing an abitrary dip of $30^{\circ}$, the actual thickness of the rock-avalanche deposit may be closer to $162 \mathrm{~m}(531 \mathrm{ft})$. The thickness of individual humps ranges from 10 to $23 \mathrm{~m} \mathrm{(32} \mathrm{to} 76 \mathrm{ft}$ ) and averages about $15 \mathrm{~m}(50 \mathrm{ft})$. Individual humps are densest in their bottom two-thirds $\left(2.65\right.$ to $\left.2.75 \mathrm{~g} / \mathrm{cm}^{3}\right)$ and tail off upward to bulk densities of 2.25 to $2.50 \mathrm{~g} / \mathrm{cm}^{3}$. It is possible that the 13 humps are the result of stratigraphic repetition of 13 landslide megabreccia sheets, each composed of dense crackle and jigsaw breccia in their bottom part and grading upward to unconfined tops characterized by less dense breccia having rotated clasts. The bulk density of the denser parts of the humps (2.65 to $\left.2.75 \mathrm{~g} / \mathrm{cm}^{3}\right)$ and the presence of abundant volcanic fragments in the cuttings indicates that the rock is probably volcanic. However, the possibility that the cuttings in this interval represent contamination means that other dense rock types cannot be ruled out.
Repetition of stratigraphic sequences along shear planes in rock-avalanche deposits is common and is discussed in the literature (for example, Kreiger, 1977), but we found no descriptions similar to the aggregate of thirteen deposits that we infer here. It is tempting to construct hypothetical conditions which might result in stacked stratigraphic sequences, for example, ramping of the avalanche body over a topographic high. However, the available one-dimensional well-log data are inadequate to resolve hypothetical models.

The rock-avalanche event probably was associated with extension on the Catalina detachment fault (Dickinson, 1991) to the north and east of the present well site. However, the location of the volcanic rocks that were the source of the deposit is not known. Both middle Tertiary and Laramide-age intermediate-composition volcanic rocks were widely distributed in the region in late Oligocene and early Miocene time. The highland that supplied the volcanic rock of the avalanche deposit was probably located to the east along a splay of the Catalina detachment fault. The splay very likely was buried beneath younger conglomerates of the Pantano Formation that later filled the basin created by displacement on the fault.

One of the whole-rock K-Ar ages $(23.4 \pm 0.6 \mathrm{Ma})$ reported by Eberly and Stanley (1978) was obtained on selected cuttings taken within the inferred rock-avalanche deposit. The location of the dated interval $(2,420-2,426 \mathrm{~m}$ [7,940-7,960 $\mathrm{ft}]$ ) is shown on figure 10, where it appears, on the basis of geophysical characteristics, to be within the upper part of one of the megabreccia sheets. The age of the rocks in the rockavalanche deposit has no bearing on the age of the Pantano, except that they must be older than the part of the Pantano Formation in which they were emplaced. Additionally, the date is queried because of the presence in the rock-avalanche interval of a significant amount of contaminant fragments of Tertiary sedimentary rocks and probably, therefore, of contaminant fragments of volcanic conglomerate clasts as well.

\section{Middle Tertiary Volcanic and Sedimentary Rocks, 2,516-3,056 m (8,256-10,026 ft)-Mio- cene(?)-Oligocene (?)}

This 540-m-thick (1,770-ft) interval consists of a diverse group of rocks with uncertain correlation to surface units. It contains the following rock units (figs. 4, 11): (1) lamprophyre(?) dike or sill, (2) intermediate-composition lava flow, (3) conglomerate, (4) crystal-lithic ash-flow tuff, (5) limestone conglomerate, and (6) pyroxene trachyte flow. Similar rocks are present south of Cienega Gap where Finnell (1971) mapped Tertiary rhyolite tuff and andesite. He assigned a Paleocene(?) age to quartz latite porphyry and to dikes and sills of lamprophyre, andesite, and diabase. In the Exxon well the crystal-lithic ash-flow tuff (our unit 4) has been determined to be upper Oligocene (see discussion below), so units 1 through 3 must be younger. However, the ages of the limestone conglomerate and pyroxene trachyte flow (units 5 and 6) are uncertain. They could be Oligocene(?), or Laramide-age 


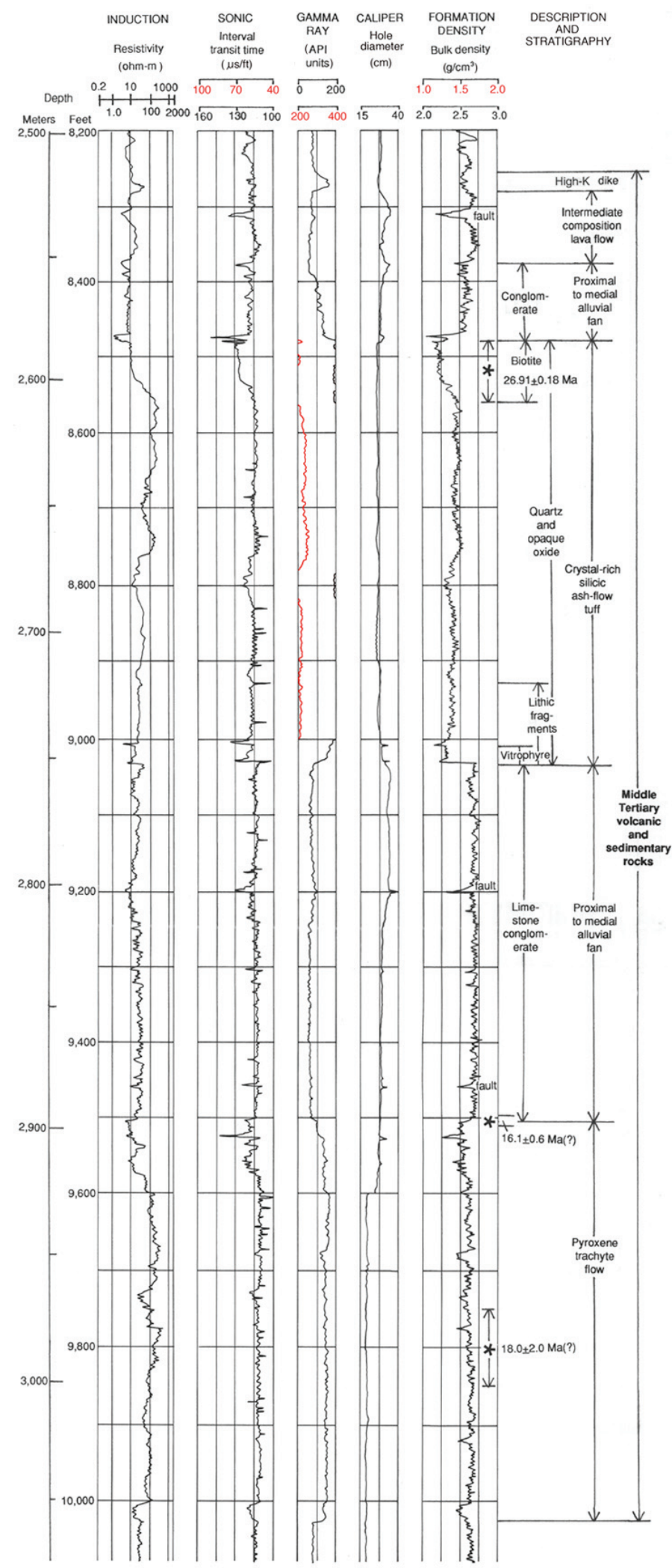

Figure 11. Geophysical logs of the middle Tertiary volcanic and sedimentary rocks, in the Exxon State (32)-1 well. Asterisks indicate location of intervals where cuttings were sampled for radiometric dates. Age of $26.91+0.18 \mathrm{Ma}$ was obtained in this study by ${ }^{40} \mathrm{Ar} /{ }^{39} \mathrm{Ar}$ analysis of biotite. Ages of 16.1+0.6 Ma and 18.0+2.0 Ma are whole-rock K-Ar ages (Eberly and Stanley, 1978).
(Paleocene and Upper Cretaceous), or they could be Upper Cretaceous. An Oligocene age is favored for the limestone because of the presence of distinctive micaceous shale and sandstone interbeds and the absence of nonmicaceous shaleshale beds in the Cretaceous sedimentary rocks of the region are not micaceous. An Oligocene age also is favored for the pyroxene trachyte, rather than a Laramide age, because no propyllitic alteration was seen in the cuttings.

\section{High-Potassium (Lamprophyre?) Dike or Sill, 2,516-2,524 m (8,256-8,280 ft)—Early Miocene or Late Oligocene}

The cuttings in this 8-m-thick (24-ft) interval consist of about 50 percent pale-red and greenish-gray shale and sandstone and 50 percent intermediate-composition volcanic fragments similar to the conglomerate in the Pantano Formation. The geophysical logs (fig. 11) show that the interval has a relatively high gamma radiation of 160 API units, and resistivity of $60 \mathrm{ohm}-\mathrm{m}$. The bulk density and interval transit time are $2.55 \mathrm{~g} / \mathrm{cm}^{3}$ and 65 microseconds/ft, respectively. Although the cuttings are similar to those of a conglomerate or intermediate-composition volcanic rock, both the gamma radiation and resistivity are higher than Pantano conglomerate above the interval (fig. 10) and higher than the middle Tertiary conglomerate and intermediate-composition volcanic rocks below the interval (fig. 11). The characteristics of this interval more closely resemble those of the pyroxene trachyte at the base of the middle Tertiary part of the section (fig. 11).

We interpret this interval to be a dike or sill of an igneous rock with a moderately high potassium content, such as trachyte, dacite, or lamprophyre. The interval of high resistivity is only about $4 \mathrm{~m}(12 \mathrm{ft})$ thick and is centered within the high gamma radiation interval. This geometry may indicate the presence of chilled margins enclosing the dike or sill. The lack of an obvious distinctive lithology in the cuttings may be attributed to the thinness of the interval and to uphole contamination.

\section{Andesite(?) Lava Flow, 2,524-2,553 m (8,280-8,376 $\mathrm{ft}$-_Upper Oligocene}

The rocks in this 29-m-thick (96-ft) interval are inferred to be intermediate-composition volcanic rocks, chiefly on the basis of the bulk density of about $2.70 \mathrm{~g} / \mathrm{cm}^{3}$ (fig. 11). The cuttings contain mostly fragments of volcanic rocks with only 10 to 20 percent shale and sandstone (probably as contaminants). A 2.5 -m-thick (8-ft) zone of low density, high interval transit time, and low resistivity at $2,533 \mathrm{~m}(8,310 \mathrm{ft})$ is interpreted to be a fault. The caliper log shows that the well diameter was enlarged considerably in this zone, which may indicate that the volcanic rocks are highly fractured. Alternatively, the low-density zone could be a flow breccia or a deuterically alterated interflow lens. 


\section{Conglomerate, 2,553-2,584 m (8,376-8,478 ft)- Upper Oligocene}

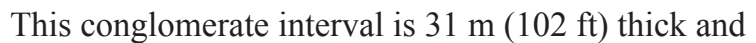
contains intermediate-composition volcanic fragments and more than 50 percent pale-red and greenish-gray shale and sandstone fragments. The shale fragments are still micaceous and calcareous, but are noticeably harder than the shale higher in the well. This is verified by comparison of the bulk density of the conglomerate overlying the rock-avalanche deposit in the Pantano Formation (about $2.50 \mathrm{~g} / \mathrm{cm}^{3}$, fig. 8) with the bulk density of this conglomerate, which is about 2.55 to 2.60 $\mathrm{g} / \mathrm{cm}^{3}$ (figs. 5,11 ). This higher bulk density indicates that this conglomerate is probably significantly older than the conglomerate in the Pantano Formation

The contact of the conglomerate with the underlying tuff is very sharp on the geophysical logs and could be either a fault or a depositional contact on an erosional surface. The contact probably is depositional, because the bottom $6 \mathrm{~m}$ (20 $\mathrm{ft}$ ) of the conglomerate contains 10 to 20 percent chips of the underlying tuff, and the gamma ray log shows that the radiation level of the conglomerate gradually increases in the lower $9 \mathrm{~m}(30 \mathrm{ft}$ ) toward the contact with the tuff (fig. 11).

\section{Silicic Tuff, 2,584-2,753 m (8,478-9,032 ft)—Upper Oligocene}

This interval is a 169 -m-thick (554-ft) crystal-lithic tuff containing crystals of biotite and quartz in the upper $25 \mathrm{~m}(82$ $\mathrm{ft}$ ) and chiefly quartz and opaque oxide in the bulk of the unit. Biotite books (with adhering tuff) collected between 2,584 and $2,609 \mathrm{~m}(8,478-8,560 \mathrm{ft})$ yielded an ${ }^{40} \mathrm{Ar} /{ }^{39} \mathrm{Ar}$ age of $26.91 \pm 0.18$ $\mathrm{Ma}$ (table 2, appendix ). Between 2,721 $\mathrm{m}(8,930 \mathrm{ft})$ and the base of the unit at 2,753 $\mathrm{m}(9,032 \mathrm{ft})$, the tuff contains andesitic lithic fragments in addition to crystals of quartz and opaque oxide. The color of the tuff varies from pale red ( $5 \mathrm{R} 6 / 2)$ to light brownish-gray (5 YR 6/1). The basal vitrophyre (2,746$2,753 \mathrm{~m}[9,008-9,032 \mathrm{ft}])$ is $7 \mathrm{~m}(24 \mathrm{ft})$ thick and consists of moderate orange-pink ( $10 \mathrm{R} 7 / 4$ ) waxy-appearing altered glass. The presence of a basal vitrophyre indicates that the tuff probably was emplaced as an ash flow rather than an ash fall.

Both the geophysical logs (fig. 11) and examination of the cuttings indicate that the tuff is relatively homogeneous and shows no sharp discontinuities, except at the top of the vitrophyre. The characteristics that define the tuff are high gamma radiation (as much as 240 API units) and lack of washouts. The caliper log indicates that the well diameter in the tuff interval was fairly constant at 25 to $28 \mathrm{~cm}$ (10-11 in). Minor variation in the bulk density suggests that the tuff may be a compound cooling unit: it is less dense below 2,682 $\mathrm{m}(8,800$ ft) (about $\left.2.40 \mathrm{~g} / \mathrm{cm}^{3}\right)$, more dense above 2,682 $\mathrm{m}(8,800 \mathrm{ft}$ ) (about $2.45 \mathrm{~g} / \mathrm{cm}^{3}$ ), and capped by a nonwelded zone at the top about $15 \mathrm{~m}(50 \mathrm{ft})$ thick. The tuff's considerable thickness and our interpretation that it was emplaced as a single compound cooling unit suggest that the tuff was derived from a nearby caldera-forming eruption.

Although ash-flow tuffs this thick commonly are welded, no traces of fiamme were seen in the cuttings. However, the apparent absence of fiamme could be a function of the small size of the cutting fragments. The regular sinusoidal pattern seen on the sonic log (fig. 11) in three intervals $(2,658-2,670$ $\mathrm{m} ; 2,694-2,716 \mathrm{~m} ; 2,723-2,737 \mathrm{~m}[8,720-8,760 \mathrm{ft} ; 8,840-8,910$ $\mathrm{ft} ; 8,935-8,980 \mathrm{ft}]$ ) may correspond to the sonic properties of densely welded tuff. This pattern is also seen on the sonic log in the trachyte interval deeper in the well, between 2,897 and $3,056 \mathrm{~m}(9,504$ and $10,026 \mathrm{ft})$, and in the granitoid rock near the bottom of the well.

\section{Limestone Conglomerate, 2,753-2,897 m (9,032- 9,504 ft)—Oligocene(?)}

This interval is a 144-m-thick (472-ft) moderately well indurated conglomerate that is composed chiefly of clasts of Paleozoic(?) limestones, with subordinate clasts of reddish andesite or dacite (some propylitically altered), grayish-red quartzite, and granitoid rocks. The overall color of the cuttings is speckled pale red (10 R 6/2) and grayish red (10 R 4/2). Fragments of pale-red (5 R 6/2) and greenish-gray (5 GY 6/1) micaceous, calcareous shale and sandstone are common. The dominance of limestone clasts is demonstrated by the density $\log$ (fig. 11), which shows that the bulk density of the conglomerate is about 2.60 to $2.75 \mathrm{~g} / \mathrm{cm}^{3}$. Figure 5 shows that the limestone conglomerate is denser in part than the underlying Lower Cretaceous Turney Ranch and Shellenberger Canyon Formations of the Bisbee Group, although the presence of micaceous shale in the cuttings (representing either matrix material or shaly interbeds) indicates that the limestone conglomerate is Tertiary rather than Cretaceous. Shale beds in the Cretaceous sedimentary rocks of the region are not micaceous.

The caliper and gamma ray logs suggest that the conglomerate may consist of two slightly different facies having a gradational contact between them at about 2,818 $\mathrm{m}(9,245$ $\mathrm{ft})$. The caliper log indicates that the well diameter was considerably enlarged, from $25 \mathrm{~cm}$ to $36 \mathrm{~cm}$ (10 in to 14 in), by washouts in the upper facies and that the conglomerate washed out uniformly, not preferentially (as in shaly interbeds, for example). The gamma radiation of the upper facies ranges from about 60 to 90 API units, whereas the lower facies shows a more uniform gamma radiation of about 60 API units. Small differences in the density, sonic, and induction logs for the two facies show that the lower facies is slightly better indurated.

There are two well defined faults at 2,804 $\mathrm{m}(9,199 \mathrm{ft})$ and at 2,882 $\mathrm{m}(9,459 \mathrm{ft})$; they are characterized by sharp decreases in bulk density and resistivity and by increases in interval transit time. Although the contact of the limestone conglomerate with the overlying tuff is very sharp, the presence of the basal vitrophyre of the tuff suggests that it is not a fault contact. 


\section{Pyroxene trachyte, 2,897-3,056 m $(9,504-10,026$ $\mathrm{ft}$-OOligocene(?)}

This 159 -m-thick (522-ft) unit is identified as a pyroxenebearing trachyte on the basis of the combination of high $\mathrm{K}_{2} \mathrm{O}$ content as indicated by the gamma ray $\log$ (fig. 11) and the presence in cuttings of pyroxene phenocrysts and large euhedral tabular feldspar crystals. Assuming the gamma ray log is measuring mostly $\mathrm{K}_{2} \mathrm{O}$ content, then the $\mathrm{K}_{2} \mathrm{O}$ content of the trachyte (140 to 160 API units) is about midway between that of the intermediate-composition volcanic rocks (80 to 120 API units) in the Pantano Formation (fig. 10), which are probably high-K calc-alkaline rocks ( 2.0 to 5.0 weight percent $\mathrm{K}_{2} \mathrm{O}$ ), and that of the silicic tuff (200 to 240 API units) (fig. 11).

Eberly and Stanley (1978) reported two whole-rock KAr dates from the trachyte of 16.1 Ma and 18.0 Ma. Because both dates are younger than the $23.4 \mathrm{Ma}$ age obtained by them from rocks higher in the well, they interpreted the younger dates to be from an intrusive dike or sill. This was a reasonable interpretation, considering that magmas of trachyte composition are highly viscous and are commonly emplaced as dikes, plugs, or short, thick flows. The cuttings provide no clues as to whether the trachyte is an intrusion or a flow, and evidence from the geophysical logs is equivocal. The balance of the evidence leans toward the trachyte being a thick extrusive flow, however, which suggests the 16.1 and 18.0 Ma dates reported by Eberly and Stanley (1978) are anomalously young (discussed below).

Evidence for a flow origin of the trachyte is shown by the geophysical logs (fig. 11). Zones at the top and bottom of the trachyte interval have lower bulk density and resistivity and higher interval transit time than the main body of trachyte. The zone at the top is about $21 \mathrm{~m}(70 \mathrm{ft})$ thick and the one at

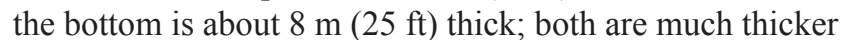
than would be expected from chilled intrusive contacts. The differences in thickness of the two zones are consistent with the zone at the top being a subaerial, brecciated flow carapace and the bottom zone being an annealed basal flow breccia. A sharp decrease in bulk density and increase in interval travel time near the middle of the top zone (fig. 11) may represent a boundary between carapace slabs.

Assuming the trachyte body is a flow, the K-Ar dates obtained by Eberly and Stanley (1978) must be in error, because the new ${ }^{40} \mathrm{Ar} /{ }^{39} \mathrm{Ar}$ age reported in this paper for biotite from the overlying silicic tuff (which is about $152 \mathrm{~m} \mathrm{(500} \mathrm{ft)}$ higher in the well than the trachyte) is $26.91 \pm 0.18 \mathrm{Ma}$ (table 2 ). The most likely cause for errors in the K-Ar whole-rock dates is contamination of the selected cuttings by similarappearing lithologies from weathered volcanic clasts in the limestone conglomerate above.

Eberly and Stanley's (1978) age of $16.1 \pm 0.6$ Ma was obtained on selected cuttings from 2,895 to 2,898 m (9,4989,508 ft). However, the geophysical logs (fig. 11) show that the upper $2 \mathrm{~m}(6 \mathrm{ft})$ of that sampled interval are in the overlying limestone conglomerate, and inspection of the cuttings show that the sampled interval as a whole contains about 50 percent limestone fragments as contamination from the limestone conglomerate. Therefore, there is a strong possibility that the selected cuttings may have contained fragments of volcanic clasts from the overlying limestone conglomerate unit, similar in appearance to the trachyte. The second interval sampled by Eberly and Stanley (1978), from 2,972 to 3,002 m $(9,751-9,850 \mathrm{ft})$ in the central part of the trachyte, yielded an age of 18.0 $\pm 2.0 \mathrm{Ma}$. While the cuttings in this interval are less contaminated than those higher in the trachyte, the contamination is still significant, and the relatively large standard deviation makes this age also suspect.

An additional indication that contamination of the selected cuttings by overlying clasts probably was the cause of the anomalously young dates for the trachyte interval is given by Eberley and Stanley's (1978) description of the rock unit. They called it a varicolored, porphyritic andesitic basalt. Our inspection of the cuttings showed that the trachyte is distinctive, uniformly light gray, fine grained, and contains large tabular feldspar phenocrysts. Numerous varicolored volcanic fragments are also present and have been washed in from uphole.

\section{Bisbee Group, 3,056-3,658 m (10,026-12,001 ft) - Lower Cretaceous and Upper Jurassic}

The Bisbee Group was described and named by Ransome (1904) for exposures in the Mule Mountains in Cochise County, Arizona (fig. 1). The formations recognized in the Mule Mountains (southeastern facies) are the basal Glance Conglomerate and overlying Morita Formation, Mural Limestone, and Cintura Formation. In the Empire and Whetstone Mountains (northwestern facies), $80 \mathrm{~km}(50 \mathrm{mi})$ northwest of the Mule Mountains and 25 to $50 \mathrm{~km}(15-30 \mathrm{mi})$ southeast of the well site, the Bisbee Group comprises five formations that are partly correlative with strata in the Mule Mountains as time equivalent facies (Tyrrell, 1957; Schafroth, 1965; Finnell, 1970a). They are the basal Glance Conglomerate and overlying Willow Canyon Formation, Apache Canyon Formation, Shellenberger Canyon Formation, and Turney Ranch Formation. The Bisbee Group ranges in age from uppermost Jurassic to lowermost Cretaceous for the Glance Conglomerate (Bilodeau and others, 1987) through Lower Cretaceous for the Turney Ranch Formation (Archibald, 1987). The Bisbee Group was deposited in the Bisbee Basin, which consisted of a series of northwest-trending en-echelon extensional subbasins at the northwestern end of the Chihuahua Trough (a northwest-trending rift basin related to the opening of the Gulf of Mexico) (Bilodeau, 1982; Dickinson and others, 1986). In southeastern Arizona, exposures of Bisbee Group rocks indicate that the Chihuahua Trough was as wide as $130 \mathrm{~km}(80 \mathrm{mi})$ and may have extended as far to the northwest as the Tucson Mountains (Risley, 1987)(fig. 1).

In the Exxon well, we correlate the 602-m-thick $(1,975$ $\mathrm{ft}$ ) interval of shale, sandstone, thin-bedded limestone, and conglomerate from 3,056 to $3,658 \mathrm{~m}(10,026-12,001 \mathrm{ft})$ with 
sedimentary rocks of the Bisbee Group. This is the interval beneath the middle Tertiary volcanic and sedimentary rocks and above granitoid rock in the bottom of the well. Except for the fact that each formation in the section is much thinner than in sections of the Bisbee Group in the Empire and Whetstone Mountains, the lithologies interpreted from the cuttings and geophysical logs correlate reasonably well with the Bisbee Group in those ranges. A comparison of the thickness of each formation in the well to its thickness in exposures in the Empire Mountains shows that the Glance Conglomerate and Willow Canyon Formation are very much thinner in the well (only 2 and 4 percent, respectively, as thick as in the Empire Mountains) but the other three formations average 30 percent as thick.

In the Empire and Whetstone Mountains, the Glance and Willow Canyon are coeval deposits of proximal and of medial to distal alluvial fans, respectively. They contain clastic debris shed southward into a subsiding half graben from the main bounding fault on the north side of this segment of the Bisbee Basin (Archibald, 1987; Soreghan, 1999). The thickness of this alluvial fan is a function of the rate of subsidence of the half graben and the rate of uplift and erosion along the fault on the north side of the basin. Although the two formations vary greatly in thickness, the Glance Conglomerate is generally about 1,525 $\mathrm{m}(5,000 \mathrm{ft})$ thick on the north end of the Empire Mountains near the paleofault and is absent on the south side of the paleobasin, whereas the Willow Canyon Formation is

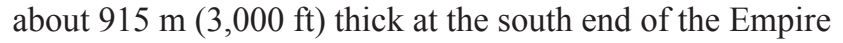
Mountains, on the south side of the paleobasin, and is absent on the north side near the paleofault.

The fact that the Glance and Willow Canyon intervals in the Exxon well are both thin suggests that the part of the Bisbee basin they were deposited in was less tectonically active than the half graben to the southeast in the Empire and Whetstone Mountains, where the alluvial fan deposits are thicker. A less active tectonic setting in the depositional basin also fits with the more moderate thinning of the remaining three units of the Bisbee Group evidenced in the Exxon well. The lithologic similarity of the Apache Canyon, Shellenberger Canyon, and Turney Ranch Formations in the well to their counterparts in the Empire and Whetstone Mountains suggests that the rate of subsidence in the basin slowed while the depositional environments along the basin axis remained the same.

\section{Turney Ranch Formation, 3,056-3,165 m (10,026- 10,384 ft)—Lower Cretaceous}

In exposures in the Empire and Whetstone Mountains, the Turney Ranch Formation has been described as a thick- to thin-bedded repetitive sequence of pale-red calcareous shale and siltstone and light pinkish-gray and pale yellowish-orange sandstone deposited as fluvial and estuarine facies in a coastal plain environment (Shafroth, 1965; Finnell, 1970a; Archibald, 1987). Lenses of arkosic pebble conglomerate contain clasts of chert, quartzite, and light-colored volcanic rocks. The

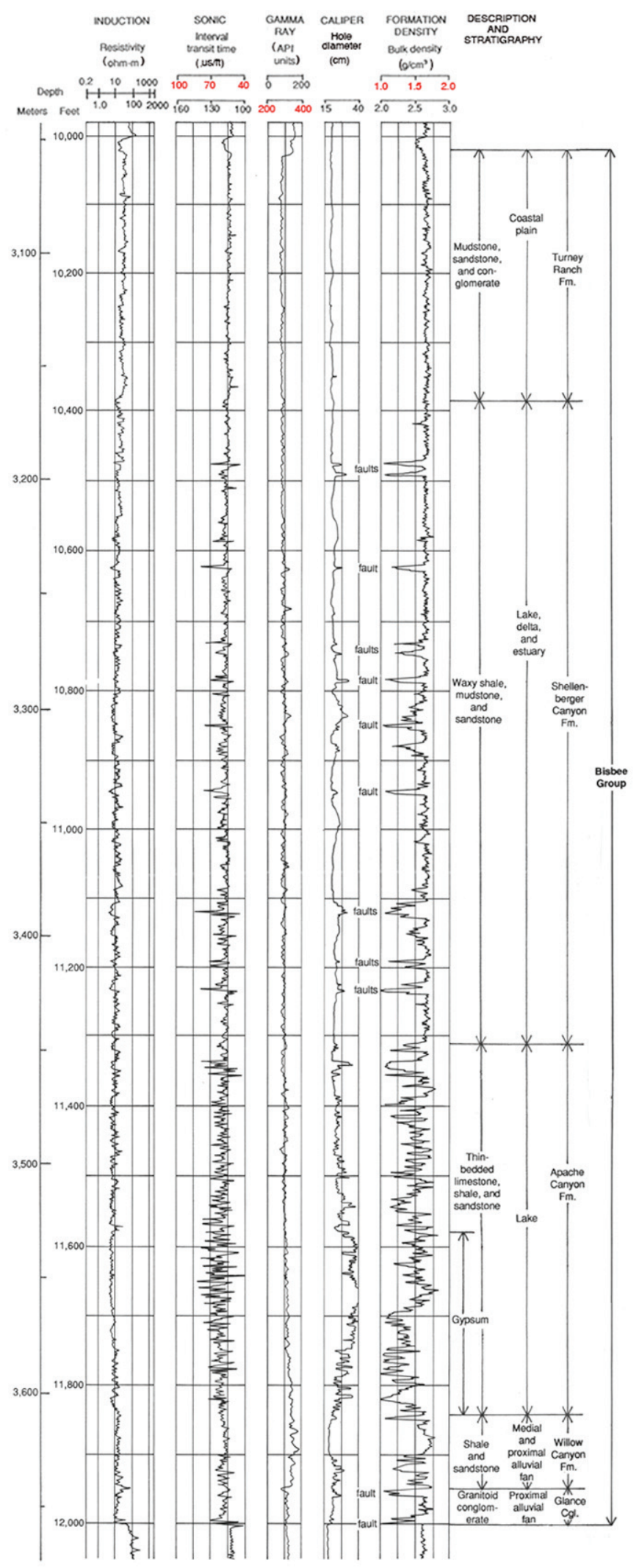

Figure 12. Geophysical logs of the Bisbee Group (Turney Ranch, Shellenberger Canyon, and Apache Canyon Formations and Glance Conglomerate), in the Exxon State (32)-1 well. Inferred depositional environments are from field studies of Tyrrell ( 1957), Schafroth (1965), Finnell (1970a), Archibald (1987), and Soreghan (1999). 
thickness ranges from more than $975 \mathrm{~m}(3,200 \mathrm{ft})$ in the Whetstones to more than $305 \mathrm{~m}(1,000 \mathrm{ft})$ in the Empire Mountains.

Geophysical logs (fig. 12) indicate that the 109-m-thick (358-ft) interval interpreted to be Turney Ranch Formation in Exxon State (32)-1 consists of uniformly well consolidated rock with an average bulk density of about $2.65 \mathrm{~g} / \mathrm{cm}^{3}$, gamma radiation of about 80 API units, average interval transit time of about 60 to $65 \mathrm{microseconds} / \mathrm{ft}$, and average resistivity of about 20 to $40 \mathrm{ohm}-\mathrm{m}$. There are no sharp spikes in any of the logs to indicate faulting, and the caliper log shows no washed-out intervals. Although these characteristics could be representative of an intermediate-composition volcanic rock instead of a consolidated sedimentary rock, there are not very many volcanic fragments in the cuttings.

The lithology of the Turney Ranch Formation in the well is difficult to determine from the cuttings, which contain considerable uphole contamination. Limestone fragments that are common to abundant indicate most of the contamination is from washouts in the limestone conglomerate interval higher in the well (2,753-2,987 m [9,032-9,504 ft]). Pale-red nonmicaceous mudstone and sandstone fragments are distinctive and probably are representative of the Turney Ranch. Other mineral grains and lithic fragments (granitoid, volcanic, limestone) could be from either conglomerate lenses in the Turney Ranch Formation or contamination from the higher limestone conglomerate.

Two main criteria were used for correlating the inferred Turney Ranch interval in Exxon State (32)-1 with sections in the Empire and Whetstone Mountains: (1) the greater bulk density of the sedimentary rocks in the interval compared to those in the Pantano Formation (fig. 5), indicating that the unit is significantly older, and (2) the presence in the cuttings of pale-red, nonmicaceous mudstone and sandstone chips similar to the lithologic descriptions of the Turney Ranch Formation in outcrop. However, because the well site is 40 to $80 \mathrm{~km}$ (25-50 mi) west of Turney Ranch exposures in the Empire and Whetstone Mountains, it is possible that the Turney Ranch Formation interval penetrated in the well had a different source area and may contain conglomerate clasts of lithology different from that at the type locality. Thus, some of the limestone fragments may come from conglomerate clasts within the Turney Ranch Formation rather than from uphole contamination.

\section{Shellenberger Canyon Formation, 3,165-3,447 m $(10,384-11,310 \mathrm{ft})$ - Lower Cretaceous}

In the Empire and Whetstone Mountains, the Shellenberger Canyon Formation consists of about 1,250 m (4,100 $\mathrm{ft}$ ) of shale, siltstone, and sandstone (Tyrrell, 1957; Schafroth, 1965; Finnell, 1970a; Archibald, 1987). About two-thirds of the section is sandstone, and some of the sandstone beds in the upper half contain thin lenses of pebble conglomerate. Most of the shale and siltstone beds and a few limestone beds are in the lower half. The predominant colors of the strata are shades of red, gray, olive, brown, and green. Archibald (1987) interpreted the depositional facies to be lacustrine, marginal lacustrine, paludal, and fluvial in the upper and middle part of the formation and marine, fluviodeltaic, and marginal lacustrine in the bottom part.

In Exxon State (32)-1, we correlate the 282-m-thick (926$\mathrm{ft})$ interval from 3,165 to $3,447 \mathrm{~m}(10,384-11,310 \mathrm{ft})$ with the Shellenberger Canyon Formation. As in the inferred Turney Ranch Formation interval, the cuttings contain considerable contamination from washouts higher in the well; however, the interval contains semi-indurated to indurated chips of nonmicaceous sandstone, mudstone, and waxy shale in distinctive colors of dusky red ( 5 R 3/4), grayish red ( 5 R 4/2), dark gray (N3), brownish gray (5 YR 4/1), and dusky brown (5 YR 2/2). These colors are similar to those described in the literature for the Shellenberger Canyon, and are differerent from those of the overlying Turney Ranch Formation and the underlying Apache Canyon Formation.

The geophysical logs (fig. 12) show that the characteristics of the Shellenberger Canyon Formation generally are similar to those of the Turney Ranch Formation, but the Shellenberger Canyon contains many thin clay-rich(?) zones of low bulk density, more numerous in the lower part of the unit. The average bulk density is about $2.65 \mathrm{~g} / \mathrm{cm}^{3}$, with spikes as low as $2.05 \mathrm{~g} / \mathrm{cm}^{3}$. The average gamma radiation is 80 to 100 API units, with spikes as high as 140 API units corresponding, in part, to the low bulk density spikes. The interval transit time is 65 to 75 microseconds/ft, slightly slower than the Turney Ranch Formation, with low sonic velocity spikes corresponding to low bulk density spikes. The resistivity of the Shellenberger Canyon Formation is also lower than that of the Turney Ranch Formation, averaging about 8 to 20 ohm-m.

The thin zones of low bulk density probably are caused by faults, some of which may be bedding-plane faults in shaly intervals. This is suggested by the presence of lens-shaped slickensided waxy shale fragments in the cuttings. The slickensided shale fragments are inferred not to be an artifact of drilling, because they are not found in any other intervals containing fine-grained sedimentary rocks.

\section{Apache Canyon Formation, 3,447-3,609 m $(11,310-11,840 \mathrm{ft})$-Lower Cretaceous}

Studies of the Apache Canyon Formation in the Whetstone Mountains (Tyrrell, 1957; Archibald, 1987) and in the Empire Mountains (Schafroth, 1965; Finnell, 1970a) indicate that it is primarily a lacustrine deposit composed of thin-bedded to laminated limestone, shale, and minor sandstone, which grades laterally and vertically (downsection) to coarser-grained alluvial-fan facies of the Willow Canyon Formation and Glance Conglomerate. The lithology of the Apache Canyon Formation interpreted from the well cuttings 
is very similar to that in exposures of the Apache Canyon in the Empire Mountains as described by Schafroth (1965) and Finnell (1970a).

Finnell estimated the Apache Canyon to be more than 488 $\mathrm{m}(1,600 \mathrm{ft})$ thick, and Schafroth measured a thickness of 265 $\mathrm{m}(870 \mathrm{ft})$. Schafroth and Finnell both placed the upper contact above the last significant limestone sequence. In the well, the contact was placed at $3,447 \mathrm{~m}(11,310 \mathrm{ft})$, which is just above the highest occurrence of black limestone fragments and corresponds to the top of the interval of highly variable density as shown on the density log (fig. 12). This interval contains the highest significant limestone beds of the Apache Formation penetrated in the well and, thus, correlates with Schaforth's and Finnell's stratigraphic interpretation.

The interval inferred to be the Apache Canyon Formation is $162 \mathrm{~m}(530 \mathrm{ft})$ thick, and the cuttings show that it consists of dark-gray to medium-dark-gray ( 3 to $\mathrm{N} 4$ ) shale, brownish-gray (5 YR 4/1) calcareous sandstone, and grayish-black (N 5) limestone. Minor amounts of gypsum are present from 3,529 to $3,609 \mathrm{~m}(11,580-11,840 \mathrm{ft})$. An unidentifiable carbonaceous plant fossil was seen on a brownish-gray shale fragment; the fragment may have washed down from the Shellenberger Canyon Formation, which contains abundant woody plant fossils (Finnell, 1970a; Archibald, 1987)

The density log (fig. 12) shows that the Apache Canyon varies greatly in bulk density (from 2.0 to $2.8 \mathrm{~g} / \mathrm{cm}^{3}$ ) across intervals less than a meter to as much as $3 \mathrm{~m}$ (10 ft) wide. Fissile shale is probably responsible for the lowest density and limestone for the highest density. The caliper log shows numerous washouts, particularly in the vicinity of the gypsiferous interval between 3,529 and 3,609 $\mathrm{m}(11,580-11,840 \mathrm{ft})$, where the well diameter washed out from $20 \mathrm{~cm}$ to more than $40 \mathrm{~cm}$ ( 8 in to more than 16 in). These characteristics indicate that the unit is thin-bedded, lithologically variable, and not uniformly indurated.

The gypsiferous interval in the bottom part of the unit may be correlative with a gypsum bed and overlying gypsiferous sequence exposed in the Empire Mountains. In the well, the interval begins at the base of the Apache Canyon and is about $80 \mathrm{~m}$ (260 ft) thick (fig. 12). In outcrop, the gypsum zone begins about $60 \mathrm{~m}(200 \mathrm{ft})$ above the base of the Apache Canyon and is about $30 \mathrm{~m} \mathrm{(100} \mathrm{ft)} \mathrm{thick} \mathrm{(Schafroth,} \mathrm{1965;}$ Finnell, 1970a).

\section{Willow Canyon Formation(?), 3,609-3,642 m (11,840-11,948 ft)-Lower Cretaceous}

In the Empire and Whetstone Mountains, the Willow Canyon Formation consists of an alternating sequence of brown and gray siltstone and locally conglomeratic lightcolored sandstone (Finnell, 1970a; Archibald, 1987). Thin limestone beds are present near the top of the formation in a marginal lacustrine facies that is gradational with lacustrine facies of the overlying Apache Canyon Formation. The bulk of the Willow Canyon Formation consists of distal and medial facies of alluvial-fan systems that grade laterally and downward to the Glance Conglomerate, which is the timeequivalent proximal alluvial-fan facies of the lower part of the Willow Canyon. Because it both overlies and intertongues with the Glance, the thickness of the Willow Canyon is highly variable in outcrops in the Empire and Whetstone Mountains, ranging from 0 to more than 1,000 $\mathrm{m}$ (about 3,000 ft).

It is not possible to identify the Willow Canyon Formation in the Exxon well on the basis of cuttings, because of the large amount of uphole contamination in the cuttings and because the lithology of the Willow Canyon (as described from outcrops) is gradational with the overlying and underlying units. In general, the cuttings in the interval that may be the Willow Canyon Formation are dark gray (N3) and brownish-gray (5YR 4/1) shale and sandstone. Dark gray shale chips in the bottom $3 \mathrm{~m}(10 \mathrm{ft})$ of the interval are pyritic.

A 33-m-thick (108-ft) interval is tentatively assigned to the Willow Canyon Formation on the basis of the following characteristics shown on the geophysical logs (fig. 12): (1) The density and sonic logs show considerably less variation in this interval than in the overlying Apache Canyon Formation.

(2) The caliper log shows that between 3,612 and 3,627 m $(11,850-11,900 \mathrm{ft})$ the well diameter was not enlarged but was constant at about $20 \mathrm{~cm}(8 \mathrm{in})$. (3) There is a steplike decrease in the gamma ray $\log$ at $3,642 \mathrm{~m}(11,948 \mathrm{ft})$ from about 150 API units to about 120. (4) At about 3,609 m (11,840 ft) there is a small but sustained increase in resistivity from slightly less than $10 \mathrm{ohm}-\mathrm{m}$ to slightly more than $10 \mathrm{ohm}-\mathrm{m}$.

\section{Glance Conglomerate, 3,642-3,658 m (11,948-12,001 ft)—Lower Cretaceous and Upper Jurassic}

A 16-m-thick (53-ft) interval consisting of interbedded medium-dark-gray (N4) calcareous shale, brownish-gray (5 YR 4/1) sandstone, and conglomerate containing unaltered to slightly chloritized granitoid clasts and medium-gray $(\mathrm{N}$ 5) limestone is interpreted to be the Glance Conglomerate. The granitoid fragments increase in abundance downward toward the top of the underlying granitoid basement(?) rock at $3,658 \mathrm{~m}(12,001 \mathrm{ft})$, from sparse at 3,642 $\mathrm{m}(11,950 \mathrm{ft})$ to about 20 percent of the sample at $3,654 \mathrm{~m}(11,990 \mathrm{ft})$. Some granitoid fragments in the interval directly overlying the granitoid rock (3,654-3,658 $\mathrm{m}$ [11,990-12,001 ft]) contain chalky weathered-looking feldspar. Limestone fragments are rare to sparse, indicating that there are relatively few limestone clasts in the conglomerate. This is suggested also by the density log (fig. 12), which shows that the density of the conglomerate assigned to the Glance is about the same as that of the underlying granitoid rock $\left(2.60-2.65 \mathrm{~g} / \mathrm{cm}^{3}\right)$. Thus, the Glance penetrated in the well is probably a granitoid-clast conglomerate with a matrix of gray shale and sandstone. It can be correlated with the upper granitoid-clast conglomerate member of the Glance described in the northern part of 
the Empire Mountains by Finnell (1970a) and Bilodeau and others (1987).

The granitoid-clast conglomerate member of the Glance Conglomerate in the northern Empire Mountains is as much as $800 \mathrm{~m}(2,625 \mathrm{ft})$ thick, whereas the interval interpreted

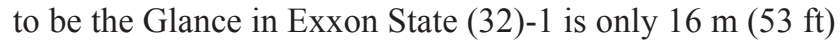
thick. This difference can be attributed to normal variation in the thickness of the Glance. The Glance Conglomerate varies greatly in thickness throughout its outcrop area, and in the northern Empire Mountains it thins toward the south to as little as $1 \mathrm{~m}$ (3 $\mathrm{ft}$ ) thick as it interfingers laterally with the Willow Canyon and Apache Canyon Formations (Finnell, 1970a; Bilodeau and others, 1987).

Zones of low-density rock $\left(2.1 \mathrm{~g} / \mathrm{cm}^{3}\right)$ about $3 \mathrm{~m} \mathrm{(10} \mathrm{ft)}$ thick at both the top and bottom of the Glance Conglomerate interval are inferred to be shear zones associated with faults (fig. 12). Resistivity peaks on the induction log suggest the presence of cemented brecciated rock about 0.5-1.0 m (2-3 ft) wide within these shear zones. It is not possible to estimate how much of the Glance section may have been cut out by the faults, but the thicknesses of the inferred shear zones implies that they are major structures. The basal fault may account for the relatively low percentage of granitoid clasts directly above the contact with granitoid rock.

\section{Granitoid Rock, 3,658-3,827 m (12,001-12,556 ft)_pre-Upper Jurassic}

Between 3,658 $\mathrm{m}(12,001 \mathrm{ft})$ and the total depth of 3,827 $\mathrm{m}(12,556 \mathrm{ft})$, Exxon State (32)-1 penetrated $169 \mathrm{~m}(555 \mathrm{ft})$ of equigranular granitoid crystalline rock, termed quartz monzonite by Eberly and Stanley (1978). In the present report, this rock is merely termed granitoid because of the difficulty of differentiating granitoid compositions from examination of cuttings. On the geophysical logs (fig. 13) and the mud log, the top of the granitoid rock appears to be at 3,658 $\mathrm{m}(12,001$ $\mathrm{ft})$, although Eberly and Stanley placed it a little lower, at 3,660 m (12,008 ft).

Eberly and Stanley (1978) reported two ages for the granitoid rock, a K-Ar whole-rock age of $61 \mathrm{Ma}$, which they said was a reduced age, and a Rb-Sr whole-rock age of 120 \pm 60 Ma. Although the contact of the overlying Upper Jurassic(?) or Lower Cretaceous Glance Conglomerate with the granitoid rock may be faulted, it was probably depositional originally as evidenced by the weathered granitoid fragments at the base of the Glance. Thus, the granitoid rock must be older than the Glance. As the Cretaceous-Jurassic boundary is about $138 \mathrm{Ma}$, it follows that the granitoid rock is very likely older than $138 \mathrm{Ma}$. It may correlate with the Triassic or Jurassic granitoid rocks of the Sierrita Mountains (Cooper, 1973); or it may correlate with either the Middle Proterozoic Oracle Granite of the Santa Catalina and Rincon Mountains (1,351 to 1,430 Ma; Reynolds and others, 1986) or the similar-age Continental Granodiorite of the Santa Rita Mountains (Drewes, 1971b). In a cross section on the Rincon Valley geologic map,
Drewes (1977) inferred the crystalline rocks in the bottom of the Exxon well to be a thrust-faulted sequence of Precambrian diabase, Pioneer Shale, Rincon Valley Granodiorite, and Cambrian Bolsa Quartzite.

The cuttings consist of about 50 percent granitoid rock and 50 percent shale, sandstone, and limestone presumably washed in from above during drilling, mainly from poorly consolidated intervals of the Apache Canyon Formation. The granitoid fragments are white, gray, pink, red, or pale green and are composed of quartz and feldspar along with muscovite, biotite, or chlorite. Mafic minerals are rare. All the granitoid fragments show mild chloritic alteration, which gives the cuttings a pale greenish cast; however, chloritic alteration is less conspicuous in the interval from about 3,776 to $3,795 \mathrm{~m}$ $(12,390-12,450 \mathrm{ft})$. Feldspar in the lithic chips in this interval is pink to red.

The geophysical logs (fig. 13) show that, although the characteristics of the granitoid rock are fairly uniform, a moderate amount of variation exists, and there may actually be two different igneous bodies separated by a fault. Over all, the bulk density varies from about 2.55 to $2.70 \mathrm{~g} / \mathrm{cm}^{3}$; the average gamma radiation is about 120 API units; the interval transit time on the sonic log averages about 60 microseconds/ft; and the resistivity is high, between 30 and $300 \mathrm{ohm}-\mathrm{m}$ in the upper part of the granite and rising to more than $1,000 \mathrm{ohm}-\mathrm{m}$ in the part of the granite below the inferred fault.

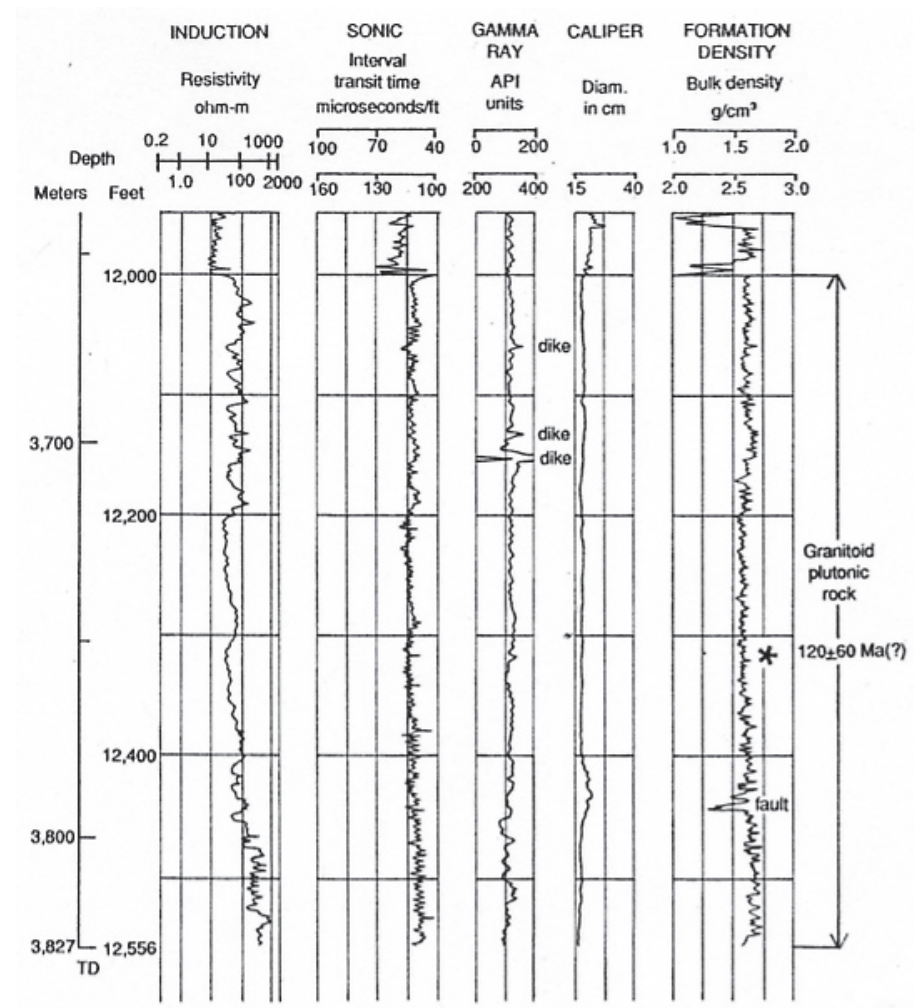

Figure 13. Geophysical logs of granitoid plutonic rock, in the Exxon State (32)-1 well. Asterisk indicates location of interval of sampled cuttings that gave a whole-rock Rb-Sr age of $120 \pm 60 \mathrm{Ma}$ (Eberly and Stanley, 1978). 
There is evidence in the geophysical logs (fig. 13) for several dikes and a fault. Two small dikes about $1 \mathrm{~m}(4 \mathrm{ft})$ wide are tentatively identified at 3,676 and 3,698 $\mathrm{m}(12,060 \mathrm{ft}$ and $12,132 \mathrm{ft}$ ). They correspond to increases in bulk density of $0.1 \mathrm{~g} / \mathrm{cm}^{3}$, lower resistivity, and peaks on the gamma ray $\log$ to about 160 API units. A feature at 3,704 m (12,154 ft),

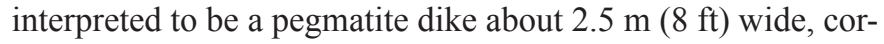
responds to a gamma ray peak of 320 API units. The sonic, density, and induction logs show no corresponding peaks for this interval in the well, which implies that, except for its high gamma-radiation level, the dike is very similar in other physical characteristics to the granitoid rock surrounding it. There are no lithologic changes in the cuttings to indicate the presence of these three dikes.

A 10-ft-wide interval of low-bulk-density rock between 3,788 and 3,792 m (12,430-12,440 ft) may be caused by a fault zone. The caliper log shows that considerable rock was washed out over a vertical distance of $15 \mathrm{~m}$ (50 ft) centered on this inferred fault zone. The cuttings in this washed-out interval change from an average of about 50 percent granitoid rock to about 20 percent granitoid rock and 80 percent dark-gray shale, black pyritic limestone, and grayish-red sandstone. It is possible that the abundant cuttings of shale, limestone, and sandstone in the interval are derived from a roughly 6-m-thick (20-ft) tectonic slice of sediment inferred to be the Apache Canyon Formation that was caught in the fault zone.

The bulk density of the rock in the faulted interval is as low as $2.30 \mathrm{~g} / \mathrm{cm}^{3}$, whereas the bulk density of the granitoid rock above the interval is about 2.58 to $2.63 \mathrm{~g} / \mathrm{cm}^{3}$ and that below the interval is about 2.63 to $2.68 \mathrm{~g} / \mathrm{cm}^{3}$. The difference in bulk density of the rock on either side of the inferred fault suggests the juxtaposition of two slightly different granitoid bodies. In addition, the rock below the faulted interval has a lower interval transit time and higher resistivity than the rock above. The sinusoidal pattern of the sonic log is slightly more pronounced and regular in the granitoid rock below the fault than in that above, which may indicate a difference in the crystalline homogeneity of the two igneous bodies.

\section{Discussion and Summary}

This section summarizes the geologic events that have shaped the Tucson basin, with particular reference to the interpretations of the cuttings and geophysical logs of the Exxon State (32)-1 well in this study. The principal events in this section are given from oldest to youngest rather than youngest to oldest as in the body of the paper (the way well data are typically presented). A comprehensive analysis of the depositional history and tectonic framework of southeastern Arizona has been presented by Dickinson (1991) in his study of the Catalina core complex.

The Proterozoic and Paleozoic geologic events that shaped the area of the present Tucson Basin were regional in extent. The granitoid pluton penetrated at the bottom of the
Exxon well probably was emplaced in Middle Proterozoic time $(1.4 \mathrm{Ga})$. This is the age of similar granite to granodiorite basement rock, overlain by Paleozoic and Mesozoic sedimentary rocks, on the flanks of the core complex that makes up the Santa Catalina Mountains and Rincon Mountains and in Cienega Gap and the Empire Mountains to the east of the well site (Reynolds and others, 1986; Reynolds, 1988; Dickinson, 1991; Drewes, 1996). The granitoid rock in the well is not mylonitic, thus indicating that it is in the hanging wall of the Catalina detachment fault.

Paleozoic (Middle Cambrian to mid-Permian) marine platform sedimentary rocks were deposited on deeply eroded Precambrian granitoid basement throughout southeastern Arizona. Although deposition was intermittent and the section records many hiatuses, a total of about $1,750 \mathrm{~m}(5,750 \mathrm{ft})$ of sediment was deposited, much of it carbonate (Peirce, 1976). Paleozoic rocks are absent at the well site, indicating they were removed by erosion prior to the latest Jurassic, when the Glance Conglomerate was deposited. However, on the basis of exposures in the surrounding mountains, remnants of the Paleozoic rocks probably are present in scattered fault blocks beneath the Tucson Basin. The 144-m-thick (472-ft) limestone conglomerate interval in the middle Tertiary volcanic and sedimentary rocks of the well demonstrates that, perhaps as late as the Oligocene, a sizeable exposure of carbonate rock was relatively close by.

Beginning in latest Jurassic time and continuing through the Early Cretaceous, northeast-southwest directed extension in southeastern Arizona and northern Mexico created the Bisbee Basin. The extension was associated with rifting of the northwest-trending Chihuahua Trough and formation of the Gulf of Mexico. The Bisbee Basin was a series of block-faulted, asymmetrical subbasins in which fluvial, lacustrine, and marine sedimentary rocks of the Bisbee Group were deposited. Paleozoic rocks may have been eroded from horst blocks during basin formation and filling. The section of Bisbee Group rocks in Exxon (32)-1 is complete, and the depositional environments appear to be the same as those of the Bisbee in the Empire and Whetstone Mountains (however, considerable uphole contamination of the cuttings makes this interpretation tenuous). A significant difference between Bisbee Group sedimentary rocks in the well and those exposed in the mountains to the southeast is that the formations in the well are only 10 to 30 percent as thick as their counterparts in outcrop. This suggests that the subsidence rate was slower in this part of the Bisbee subbasin.

Upper Cretaceous sedimentary and volcanic rocks (Fort Crittenden Formation) and Laramide-age (Late Cretaceous and Paleocene) hypabyssal intrusive granodiorite and quartz monzonite and associated volcanic rocks are widespread but scattered in the region, and were not penetrated in the Exxon well. If Upper Cretaceous and Paleocene sedimentary and volcanic rocks were deposited at the well site, they were removed by erosion, probably during the Eocene.

Products of mid-Tertiary volcanism and extension are well represented in the Exxon well (see Dickinson (1991) for a 
discussion of this period of tectonism). Interbedded volcanic and sedimentary rocks emplaced or deposited during the initial phase of extension consist of $168 \mathrm{~m}(522 \mathrm{ft})$ of pyroxene trachyte, $142 \mathrm{~m}$ (472 ft) of limestone conglomerate, $169 \mathrm{~m} \mathrm{(554}$ $\mathrm{ft})$ of ash-flow tuff, $31 \mathrm{~m}(102 \mathrm{ft})$ of conglomerate, and $29 \mathrm{~m}$ $(96 \mathrm{ft})$ of intermediate-composition volcanic rocks. There is also a contemporaneous 8 -m-thick (24-ft) dike or sill. The pyroxene trachyte is assumed to be Oligocene because of the lack of alteration of its cuttings and the late Oligocene age of the stratigraphically higher ash-flow tuff. Although the possibility that the trachyte is Late Cretaceous or Laramide in age cannot be ruled out, volcanic rocks of these ages in the area commonly are propylitically altered. K-Ar age dates of 18.0 and 16.1 Ma reported by Eberly and Stanley (1978) for the pyroxene trachyte probably reflect the presence of uphole contamination.

Although volcaniclastic conglomerate units are quite common in exposed middle Tertiary volcanic terranes in southeastern Arizona, where many appear to be medial to distal lahar deposits, the presence of nearly $150 \mathrm{~m}(500 \mathrm{ft})$ of limestone conglomerate underlain and overlain by volcanic rocks is unusual. It implies that crustal extension or volcanism had created a local fault-bounded basin in the vicinity of the well and that the basin was being filled by alluvial-fan facies sediments principally derived from a nearby upland of Paleozoic carbonate rock. The depositional setting may have been similar to that of the mid-Tertiary Cloudburst and Mineta Formations exposed on the flanks of the San Pedro Basin to the northeast (Dickinson, 1991).

The 169-m-thick (554-ft) ash-flow tuff overlying the limestone conglomerate records an instant in geologic time when a caldera-forming eruption occurred within a few tens of kilometers of the well site and terminated deposition of the limestone conglomerate. The only radiometric age in the well that we consider to be reliable is the ${ }^{40} \mathrm{Ar} /{ }^{39} \mathrm{Ar}$ date of 26.91 Ma obtained in this study on biotite from this ash-flow tuff (table 2; appendix). The basin that contained the limestone conglomerate probably continued to subside after it was filled with ash-flow tuff. Thus, the $31 \mathrm{~m}(102 \mathrm{ft})$ of volcaniclastic conglomerate that overlies the ash-flow tuff may indicate continued deposition in the same basin, but with a source area modified (no exposed limestone) by the blanket of ash-flow tuff.

The 636-m-thick (2,086-ft) Pantano Formation is inferred to represent syntectonic upper-plate response to the second phase of mid-Tertiary volcanism and extension of the region, which was characterized by extensional shear zones at midcrustal levels beneath subhorizontal detachment faults. This inference is drawn chiefly by analogy to exposures of the Pantano Formation in Cienega Gap and in the Catalina Foothills, where the formation is complexly tilted and faulted, is in direct contact with the detachment fault in places, and is overlain by a rock-avalanche deposit. Displacement on the Catalina detachment fault, which included doming and the beginning of denudation of the core complex (Dickinson, 1991), probably began at about $25 \mathrm{Ma}$, near the end of the Oli- gocene, and continued to at least $20 \mathrm{Ma}$ and perhaps longer. This timing is in agreement with the age of about $25 \mathrm{Ma}(\mathrm{K}-\mathrm{Ar}$ on plagioclase from andesite) for the Pantano in Cienega Gap, although, as discussed above in the section on the Pantano Formation, we suggest caution in using this date because of alteration of the andesite.

The Pantano Formation in Exxon (32)-1 is thinner, but quite similar lithologically, to the Pantano in outcrop in Cienega Gap and, apparently, similar to the Pantano in the Catalina Foothills, although the exposures there are not as good. Both in outcrop and in the Exxon well, the formation consists chiefly of moderately well consolidated muddy conglomerate, gypsiferous in part; in Cienega Gap it also contains an andesite flow and is capped by a rock-avalanche deposit. If the deposition of the Pantano was approximately coeval in the Catalina Foothills, at the Exxon well site (middle of the present Tucson Basin), and in Cienega Gap, the depositional basin was a large one, at least $60 \mathrm{~km}$ by $25 \mathrm{~km}$ (about $40 \mathrm{mi}$ by $15 \mathrm{mi}$ ) (fig. 1). Reconstruction of the late Oligocene to early Miocene geography of the area, based on Dickinson's (1991) estimate that the upper plate of the Catalina detachment fault was displaced $20-30 \mathrm{~km}$ to the southwest relative to the lower plate, places the Pantano depositional basin more or less squarely on top of the present Catalina core complex. This perhaps is not surprising, because this may be where midcrustal extension was greatest and, therefore, where an extensional basin was most likely to form. The relative stratigraphic position of the rock-avalanche deposits (at the bottom of the Pantano in the Exxon well and at the top of the formation at Cienega Gap) may reflect eastward migration (as a function of time) of splay faults propagating upward from the Catalina detachment fault during deposition of the Pantano.

The Tucson Basin contains more than 1,880 m $(6,000$ $\mathrm{ft}$ ) of basin-fill sedimentary rocks, about equally divided between lower basin-fill and upper basin-fill deposits. The age of the basin fill is not constrained for the Tucson basin. However, an approximate age for the base of the lower basinfill deposits is given by an ${ }^{40} \mathrm{Ar} /{ }^{39} \mathrm{Ar}$ age for an ash-fall tuff interbedded near the base of the Nogales Formation in the upper Santa Cruz Valley (fig. 1). Sanidine crystals in that tuff were dated at $15.53 \mathrm{Ma}$ or $17.38 \mathrm{Ma}$ (table 2; see also fig. 16 , in the appendix). A minumum age for the upper basin-fill deposits of late Pliocene to early Pleistocene is based on the ages of deposits in nearby basins (table 3 ).

The basin-fill units are deposits of alluvial fans and playas. The chief differences between the lower and upper basin fill are that the lower fill is better consolidated and is significantly faulted whereas the upper fill does not appear, on the basis of the geophysical logs, to be faulted at all. The boundary separating the upper and lower basin-fill units has regional tectonic significance, because a similar boundary can be recognized in all the basins in Arizona and New Mexico where the basin fill has been mapped in detail (table 3). It represents a recognizable hiatus of perhaps a few million years and signals a change in tectonic activity. 
The uppermost $341 \mathrm{~m}$ (1,120 ft) of upper basin-fill sediments at the well site are deposits of a low-gradient alluvial fan, herein named the Cienega Creek Fan. The fan head is at the mouth of Cienega Creek at the east side of the Tucson Basin. The source of sediment for the fan was older basin fill and bedrock in the area of Cienega Gap, Davidson Canyon, and the lower part of Cienega Creek. Field relations indicate that these drainages were sediment-filled basins when deposition of the alluvial fan began. Nearly all of Cienega Gap and Davidson Canyon have been exhumed and basin-fill alluvium has been eroded from the lower part of Cienega Creek Valley. The event, whether climatic or tectonic, that triggered the erosion of basin fill from these three areas has not been identified, but is currently being investigated.

\section{References Cited}

Archibald, L.E., 1987, Stratigraphy and sedimentology of the Bisbee Group in the Whetstone Mountains, southeastern Arizona, in Dickinson, W.R., and Klute, M.A., eds., Mesozoic rocks of southern Arizona and adjacent areas: Tucson, Arizona Geological Society Digest XVIII, p. 273-282.

Anderson, S.R., 1987, Cenozoic stratigraphy and geologic history of the Tucson basin, Pima County, Arizona: U.S. Geological Survey Water-Resources Investigations Report 87-4190, 20 p., scale 1:250,000.

Balcer, R.A., 1984, Stratigraphy and depositional history of the Pantano Formation (Oligocene-early Miocene), Pima County Arizona: Tucson, University of Arizona Master's Thesis, 107 p.

Banks, N.G., 1974, Reconnaissance geologic map of the Mount Lemmon quadrangle, Arizona: U.S. Geological Survey Miscellaneous Field Studies Map MF 747, scale 1:62,500.

Beratan, K.K., 1998, Structural control of rock-avalanche deposition in the Colorado River extensional corridor, southeastern California-western Arizona, in Faulds, J.E., and Stewart, J.H., eds., Accomodation zones and transfer zones- the regional segmentation of the Basin and Range Province: Geological Society of America Special Paper 323, p. 115-125.

Bilodeau, W.L., 1982, Tectonic models for Early Cretaceous rifting in southeastern Arizona: Geology, v. 10, p. 466-470.

Bilodeau, W.L., Kluth, C.F., and Vedder, L.K., 1987, Regional stratigraphic, sedimentologic, and tectonic, relationships of the Glance Conglomerate in southeastern Arizona, in Dickinson, W.R., and Klute, M.A., eds., Mesozoic rocks of southern Arizona and adjacent areas: Tucson, Arizona Geological Society Digest XVIII, p. 229-256.

Brennan, A.J., 1957, Geological reconnaissance of Cienega Gap, Pima County, Arizona: Tucson, University of Arizona Ph.D. Dissertation, $53 \mathrm{p}$.

Brown, S.G., Davidson, E.S., Kister, L.R., and Thomsen, B.W., 1966, Water Resources of Fort Huachuca Military Reservation, southeastern Arizona: U.S. Geological Survey Water-Supply Paper 1819-D, p. D1-D57.

Cooper, J.R., 1973, Geologic map of the Twin Buttes quadrangle, southwest of Tucson, Pima County, Arizona: U.S. Geological Survey Miscellaneous Investigations Series Map I-745, scale $1: 48,000$.

Creasey, S.C., 1965, Geology of the San Manuel area, Pinal County, Arizona: U.S. Geological Survey Professional Paper 471, 64 p.

Damon, P.E., Shafiqullah, M., Harris, R.C., and Spencer, J.E., 1996 (updated 1997), Compilation of unpublished Arizona $\mathrm{K}$-Ar dates from the University of Arizona Laboratory of Isotope Geochemistry: Tucson, Arizona Geological Survey Open-File Report 96-18, 53 p.

Davidson, E.S., 1973, Geohydrology and water resources of the Tucson basin, Arizona: U.S. Geological Survey Water-Supply Paper 1939-E, p. E1-E81.

Davis, R.W., 1971, An analysis of gravity data from the Tucson basin, Arizona: Tucson, Arizona Geological Society Digest IX, p. 103-121.

Deino, Alan, and Potts, Richard, 1990, Single-crystal ${ }^{40} \mathrm{Ar} /{ }^{39} \mathrm{Ar}$ dating of the Olorgesailie Formation, Southern Kenya Rift: Journal of Geophysical Research, v. 95, p. 8453-8470.

Dickinson, W.R., 1991, Tectonic setting of faulted Tertiary strata associated with the Catalina core complex in southern Arizona: Geological Society of America Special Paper 264, 106 p., scale 1:125,000.

Dickinson, W.R., 1999, Geologic framework of the Catalina foothills, outskirts of Tucson, Pima County, Arizona: Tucson, Arizona Geological Survey Contributed Map CM-99-B, 31 p., scale 1:24,000.

Dickinson, W.R., Klute, M.A., and Swift, P.N., 1986, The Bisbee basin and its bearing on late Mesozoic paleogeographic and paleotectonic relations between the Cordilleran and Caribbean regions, in Abbott, P.L., ed., Cretaceous stratigraphy, western North America: Los Angeles, Society of Economic Paleontologists and Mineralogists, Pacific Section, Book 46, p. 51-62.

Drewes, Harald, 1971a, Geologic map of the Sahuarita quadrangle, southeast of Tucson, Pima County, Arizona: U.S. Geological Survey Miscellaneous Investigations Series Map I-613, Scale 1:48,000.

Drewes, Harald, 1971b, Geologic map of the Mount Wrightson quadrangle, southeast of Tucson, Santa Cruz and Pima Counties, Arizona: U.S. Geological Survey Miscellaneous Investigations Series Map I-614, scale 1:48,000.

Drewes, Harald, 1977, Geologic map and sections of the Rincon Valley quadrangle, Pima County, Arizona: U.S. Geological Survey Miscellaneous Investigations Series Map I-977, scale 1:48,000.

Drewes, Harald, 1996, Geology of Coronado National Forest, in du Bray, E.A., ed., Mineral resource potential and geology of Coronado National Forest, southeastern Arizona and southwestern New Mexico: U.S. Geological Survey Bulletin 2083-A-K, p. B17- B41.

Eberly, L.D., and Stanley, T.B., Jr., 1978, Cenozoic stratigraphy and geologic history of southwestern Arizona: Geological Society of America Bulletin, v. 89, p. 921-940.

Finnell, T.L., 1970a, Formations of the Bisbee Group, Empire Mountains quadrangle, Pima County, Arizona, in Cohee, 
G.V., Bates, R.G., and Wright, W.B., Changes in stratigraphic nomenclature by the U.S. Geological Survey, 1968: U.S. Geological Survey Bulletin 1294-A, p. A28-A35.

Finnell, T.L., 1970b, Pantano Formation, in Cohee, G.V., Bates, R.G., and Wright, W.B., Changes in stratigraphic nomenclature by the U.S. Geological Survey, 1968: U.S. Geological Survey Bulletin 1294-A, p. A35-A36.

Finnell, T.L., 1971, Preliminary geologic map of the Empire Mountains quadrangle, Pima County, Arizona: U.S. Geological Survey Open-File Report 71-106, scale 1:48,000.

Force, E.R., 1997, Geology and mineral resources of the Santa Catalina Mountains, southeastern Arizona: Tucson, Center for Mineral Resources, University of Arizona and U.S. Geological Survey, Monographs in Mineral Resource Science No. $1,135 \mathrm{p}$.

Galusha, Theodore, Johnson, N.M., Lindsay, E.H., Opdyke, N.D., and Tedford, R.H., 1984, Biostratigraphy and magnetostratigraphy, late Pliocene rocks, 111 Ranch, Arizona: Geological Society of America Bulletin, v. 95, p. 714-722.

Gettings, M.E., and Houser, B.B., 1997, Basin geology of the upper Santa Cruz Valley, Pima and Santa Cruz Counties, southeastern Arizona: U.S. Geological Survey Open-File Report 97-676, 40 p., 6 pls.

Gray, R.S., 1967, Petrography of the upper Cenozoic non-marine sediments in the San Pedro Valley, Arizona: Journal of Sedimentary Petrology, v. 37, p. 774-789.

Goddard, E.N., Trask, P.D., De Ford, R.K., Rove, O.N., Singewald, J.T., and Overbeck, R.M., 1975, Rock color chart: distributed by Geological Society of America.

Helmick, W.R., 1986, The Santa Cruz River terraces near Tubac, Santa Cruz County, Arizona; Tucson, University of Arizona Master's thesis, $96 \mathrm{p}$.

Hilchie, D.W., 1978, Applied Openhole Log Interpretation: Golden, Colorado, Douglas W. Hilchie, Inc.

Houser, B.B., 1987, Geologic map of the Alma quadrangle, Catron County, New Mexico: U.S. Geological Survey, Geological Quadrangle Map GQ-1610, scale 1:24,000.

Houser, B.B., 1994, Geology of the late Cenozoic Alma basin, New Mexico and Arizona, in Chamberlin, R.M., Kues, B.S., Cather, S.M., Barker, J. M., and McIntosh, W.C., eds., Mogollon Slope, west-central New Mexico and east-central Arizona: Socorro, New Mexico Geological Society Forty-Fifth Annual Field Conference, p. 121-124.

Houser, B.B., Richter, D.H., and Shafiqullah, M., 1985, Geologic map of the Safford quadrangle, Graham County, Arizona: U.S. Geological Survey Miscellaneous Investigations Series Map I-1617, scale 1:48,000.

Hsü, K.J., 1975, Catastrophic debris streams (sturzstroms) generated by rockfalls: Geological Society of America Bulletin, v. 86 , p. $129-140$.

Johnson, N.M., Opdyke, N.D., and Lindsay, E.H., 1975, Magnetic polarity stratigraphy of Pliocene-Pleistocene terrestrial deposits and vertebrate faunas, San Pedro Valley, Arizona: Geological Society of America Bulletin, v. 86, p. 5-12.

Kent, P.E., 1966, The transport mechanism in catastrophic rock falls: Journal of Geology, v. 74, p. 79-83.
Keys, W.S., and MacCary, L.M., 1971, Application of borehole geophysics to water-resources investigations: Techniques of Water-Resources Investigations of the United States Geological Survey, Book 2 - Collection of Environmental Data, Chapter E1, 126 p.

Kreiger, M.H., 1977, Large landslides, composed of megabreccia, interbedded in Miocene basin deposits, southeastern Arizona: U.S. Geological Survey Professional Paper 1008, 25 p.

Kruger, J.M., Johnson, R.A., and Houser, B.B., 1995, MiocenePliocene half-graben evolution, detachment faulting and late-stage core complex uplift from reflection seismic data in southeast Arizona: Basin Reasearch, v. 7, p 129-149.

Lindsay, E.H., Opdyke, N.D., and Johnson, N.M., 1984, BlancanHemphillian land mammal ages and late Cenozoic mammal dispersal events: Annual Reviews of Earth and Planetary Science, v. 12, p. 445-488.

Lipman, P.W., 1993, Geologic map of the Tucson Mountains caldera, southern Arizona: U.S. Geological Survey Miscellaneous Investigations Series Map I-2205, scale 1:24,000.

Litinsky, V.A., 1989, Concept of effective density - key to gravity depth determinations for sedimentary basins: Geophysics, v. 54, p. 1474-1482.

Machette, M.N., Personius, S.F., Menges, C.M., and Pearthree, P.A., 1986, Map showing Quaternary and Pliocene faults in the Silver City $1^{\circ} \times 2^{\circ}$ quadrangle and the Douglas $1^{\circ} \times 2^{\circ}$ quadrangle, southeastern Arizona and southwestern New Mexico: U.S. Geological Survey Miscellaneous Field Studies Map MF-1465-C, scale 1:250,000.

Mahon, K.I., 1996, The new "York" regression - application of an improved statistical method to geochemistry: International Geology Review, v. 38, p. 293-303.

Marvin, R.F., Naeser, C.W., and Mehnert, H.H., 1978, Tabulation of radiometric ages, including unpublished $\mathrm{K}-\mathrm{Ar}$ and fission-track ages, for rocks in southeastern Arizona and southwestern New Mexico, in Callender, J.F., Wilt, J.C., Clemons, R.E., and James, H.L., eds., Land of Cochise: Socorro, New Mexico Geological Society $29^{\text {th }}$ Field Conference Guidebook, p. 243-252.

Melosh, H.J., 1983, Acoustic fluidization: American Scientist, v. 71, p. $158-165$.

Menges, C.M., and McFadden, L.D., 1981, Evidence for a latest Miocene to Pliocene transition from Basin-Range tectonic to post-tectonic landscape evolution in southeastern Arizona: Tucson, Arizona Geological Society Digest XIII, p. 151-160.

Menges, C.M., and Pearthree, P.A., 1989, Late Cenozoic tectonism in Arizona and its impact on regional landscape evolution, in Jenny, J.P. and Reynolds, S.J., eds., Geologic evolution of Arizona: Tucson, Arizona Geological Society Digest XVII, p. 649-680.

Merkel, R.H., 1979, Well log formation evaluation: American Association of Petroleum Geologists, Continuing Education Course Note Series \#14, 82 p.

Pashley, E.F., Jr., 1966, Structure and stratigraphy of the central, northern, and eastern parts of the Tucson basin: Tucson, University of Arizona Ph.D. Dissertation, 273 p.

Pearthree, P.A., and Calvo, S.S., 1987, The Santa Rita fault 
zone-evidence for large magnitude earthquakes with very long recurrence intervals in the Basin and Range province of southeastern Arizona: Bulletin of the Seismological Society of America, v. 77, p. 97-116.

Pearthree, P.A., McKittrick, M.A., Jackson, G.W., Demsey, K.A., 1988, Geologic map of Quaternary and upper Tertiary deposits, Tucson $1^{\circ} \times 2^{\circ}$ quadrangle, Arizona: Tucson, Arizona Geological Survey Open-File Report 88-21, scale 1:250,000.

Peirce, H.W., 1976, Elements of Paleozoic tectonics in Arizona: Tucson, Arizona Geological Society Digest IX, p. 37-57.

Ransome, F.L., 1904, Bisbee folio: U.S. Geological Survey, Geologic Atlas of the United States, no. 112.

Reynolds, S.J., 1988, Geologic map of Arizona: Tucson, Arizona Geological Survey, Map 26, scale 1:1,000,000.

Reynolds, S.J., Florence, F.P., Welty, J.W., Roddy, M.S., Currier, D.A., Anderson, A.V., and Keith, S.B., 1986, Compilation of radiometric age determinations in Arizona: Tucson, Arizona Bureau of Geology and Mineral Technology Bulletin 197, $258 \mathrm{p}$.

Richter, D.H., Shafiqullah, M., and Lawrence, V.A., 1981, Geologic map of the Whitlock Mountains, Graham County, Arizona: U.S. Geological Survey Miscellaneous Investigations Series Map I-1302, scale 1:48,000.

Richter, D.H., Houser, B.B., and Damon, P.E., 1983, Geologic map of the Guthrie quadrangle, Graham and Greenlee Counties, Arizona: U.S. Geological Survey Miscellaneous Investigations Series Map I-1455, scale 1:48,000.

Risley, Rob, 1987, Sedimentation and stratigraphy of the Lower Cretaceous Amole Arkose, Tucson Mountains, Arizona, in Dickinson, W.R., and Klute, M.A., eds., Mesozoic rocks of southern Arizona and adjacent areas: Tucson, Arizona Geological Society Digest XVIII, p. 215-228.

Samson, S.D., and Alexander, E.C., Jr., 1987, Calibration of the interlaboratory ${ }^{40} \mathrm{Ar} /{ }^{39} \mathrm{Ar}$ dating standard, Mmhb-1: Chemical Geology, v. 66, p. 27-34.

Scarborough, R.B., 1975, Chemistry and age of late Cenozoic air-fall ashes in southeastern Arizona: Tucson, University of Arizona Master's Thesis, $107 \mathrm{p}$.

Scarborough, R.B., and Peirce, H.W., 1978, Late Cenozoic basins of Arizona, in Callender, J.F., Wilt, J.C., Clemons, R.E., and James, H.L., eds., Land of Cochise: Socorro, New Mexico Geological Society $29^{\text {th }}$ Field Conference Guidebook, p. 253-259.

Schafroth, D.W., 1965, Structure and stratigraphy of the Cretaceous rocks south of the Empire Mountains, Pima and Santa Cruz Counties, Arizona: Tucson, University of Arizona Ph.D. Dissertation, $135 \mathrm{p}$.

Shafiqullah, M., Damon, P.E., Lynch, D.J., Kuck, P.H., and Rerhig, W.A., 1978, Mid-Tertiary magmatism in southeastern Arizona in Callender, J.F., Wilt, J.C., Clemmons, R.E., and James, H.L., eds., Land of Cochise: Socorro, New Mexico Geological Society $29^{\text {th }}$ Field Conference Guidebook, p. 231-241.

Shreve, R.L., 1968, The Blackhawk landslide: Geological Soci- ety of America Special Paper 108, 47 p.

Simons, F.S., 1974, Geologic map and sections of the Nogales and Lochiel quadrangles, Santa Cruz County, Arizona: U.S. Geological Survey Miscellaneous Investigations Series Map I-762, scale 1:48,000.

Smith, W.J., 1967, Cenozoic stratigraphy near Redington, Pima County, Arizona: Tucson, University of Arizona Master's Thesis, $96 \mathrm{p}$.

Soreghan, M.J., 1999, Facies distribution within an ancient asymmetric lake basin - the Apache Canyon Formation, Bisbee basin, Arizona, in Pitman, J.K., and Carroll, A. R., eds., Modern and ancient lake systems: Utah Geological Association Guidebook 26, p.163-190.

Spencer, J.E., and Reynolds, S.J., 1989, Middle Tertiary tectonics of Arizona and adjacent areas, in Jenney, J.P., and Reynolds, S.J., eds., Geologic evolution of Arizona: Tucson, Arizona Geological Society Digest XVII, p. 539-574.

Steiger, R.H., and Jager, E., 1977, Subcommission on geochronology - convention on the use of decay constants in geo- and cosmochronology: Earth and Planetary Science Letters, v. 36, p. 359-362.

Sweeney, R.S., 2000, Three aeromagnetic surveys in south central Arizona - a web site for distribution of data (on-line edition): U.S. Geological Survey Open-File Report 00-155, http://greenwood.cr.usgs.gov/pub/open-file-reports/ofr-00155/scarizona.html

Taylor, J.R., 1982, An introduction to error analysis - the study of uncertainties in physical measurements: Mill Valley, California, University Science Books, $270 \mathrm{p}$.

Telford, W.M., Geldart, L.P., Sheriff, R.E., and Keys, D.A., 1976, Applied Geophysics: London, Cambridge University Press, $2^{\text {nd }}$ edition, $860 \mathrm{p}$.

Tyrrell, W.W., 1957, Geology of the Whetstone Mountains area, Cochise and Pima Counties, Arizona: New Haven, Conn., Yale University Ph.D. Dissertation, $171 \mathrm{p}$.

Voelger, Klaus, 1953, Cenozoic deposits in the southern foothils of the Santa Catalina Mountains near Tucson, Arizona: Tucson, University of Arizona Master's Thesis, $101 \mathrm{p}$.

Wrucke, C.T., Bromfield, C.S., Simons, F.S., Greene, R.C., Houser, B.B., Miller, R.J., and Gray, Floyd, 2004, Geologic map of the San Carlos Indian reservation, Arizona: U.S. Geological Survey Miscellaneous Investigations Series Map I-2780, scale 1:125,000.

Yarnold, J.C., 1993, Rock-avalanche characteristics in dry climates and the effect of flow into lakes - insights from mid-Tertiary sedimentary breccias near Artillery Peak, Arizona: Geological Society of America Bulletin, v. 105, p. 345-360.

Yarnold, J.C. and Lombard, J.P., 1989, A facies model for large rock-avalanche deposits formed in dry climates, in Colburn, I.P., Abbott, P.L., and Minch, John, eds., Conglomerates in basin analysis - a symposium dedicated to A.O. Woodward: Pacific Section Society of Economic Paleontologists and Mineralogists, v. 62, p. 9-31. 


\section{APPENDIX: AGE SPECTRA AND PROBABILITY DISTRIBUTION DIAGRAMS FOR ${ }^{40} \mathrm{AR} /{ }^{39} \mathrm{AR}$ DETERMINATIONS}

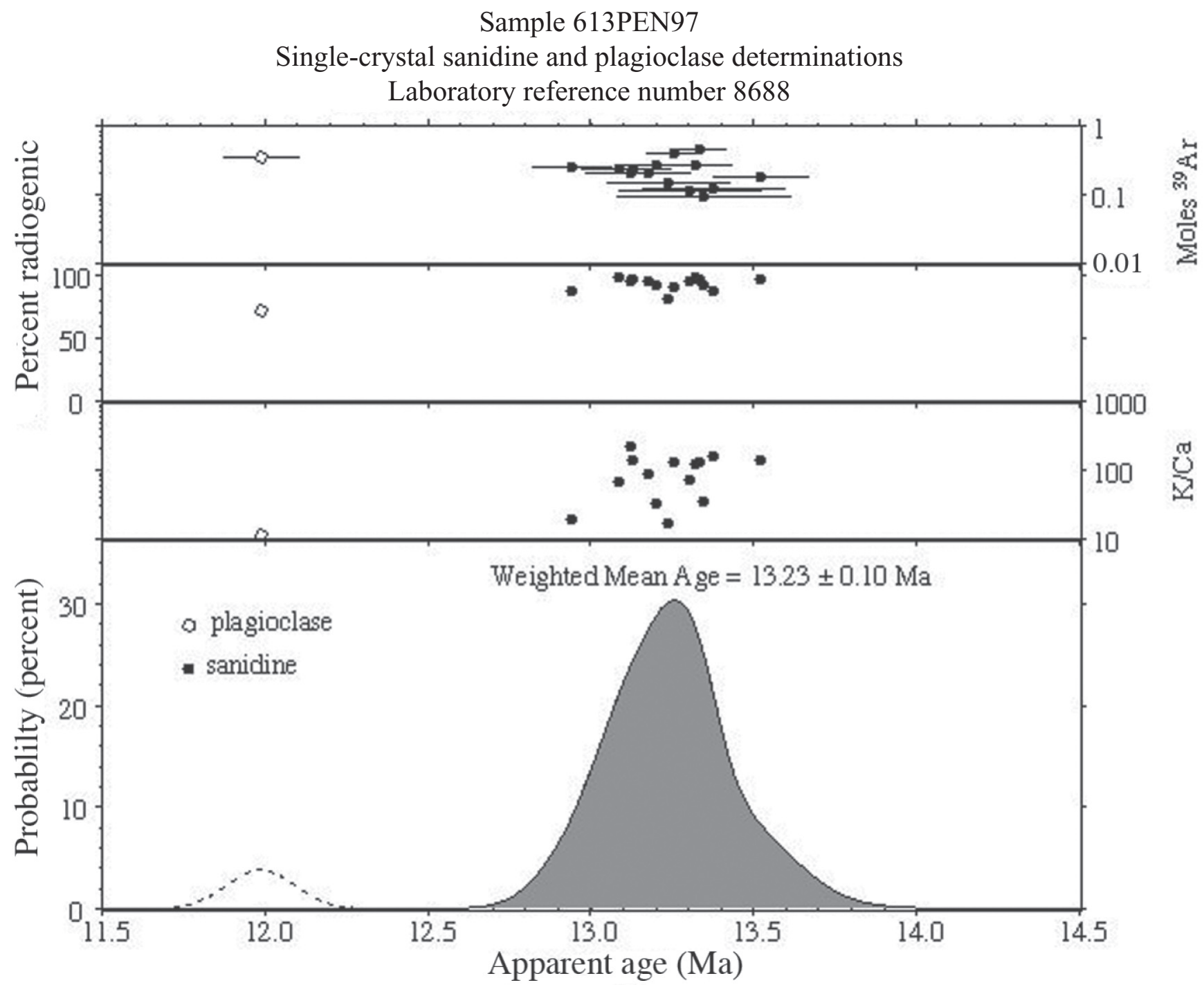

Figure 14. Age probability distribution diagram or ideogram for the 613PEN97 feldspar separate (Nogales Formation). The weighted mean of the fourteen single-crystal sanidine ages $(13.23 \pm 0.10 \mathrm{Ma})$ is the preferred age for this sample. The plagioclase crystal that yielded an anomalously young age was probably altered (as supported by its lower K/Ca ratio and lower radiogenic yield) and was not used in calculating the mean. Error bars are two sigma. 


\section{Sample 615BAT99}

Single-crystal sanidine and plagioclase determinations Laboratory reference number 51009

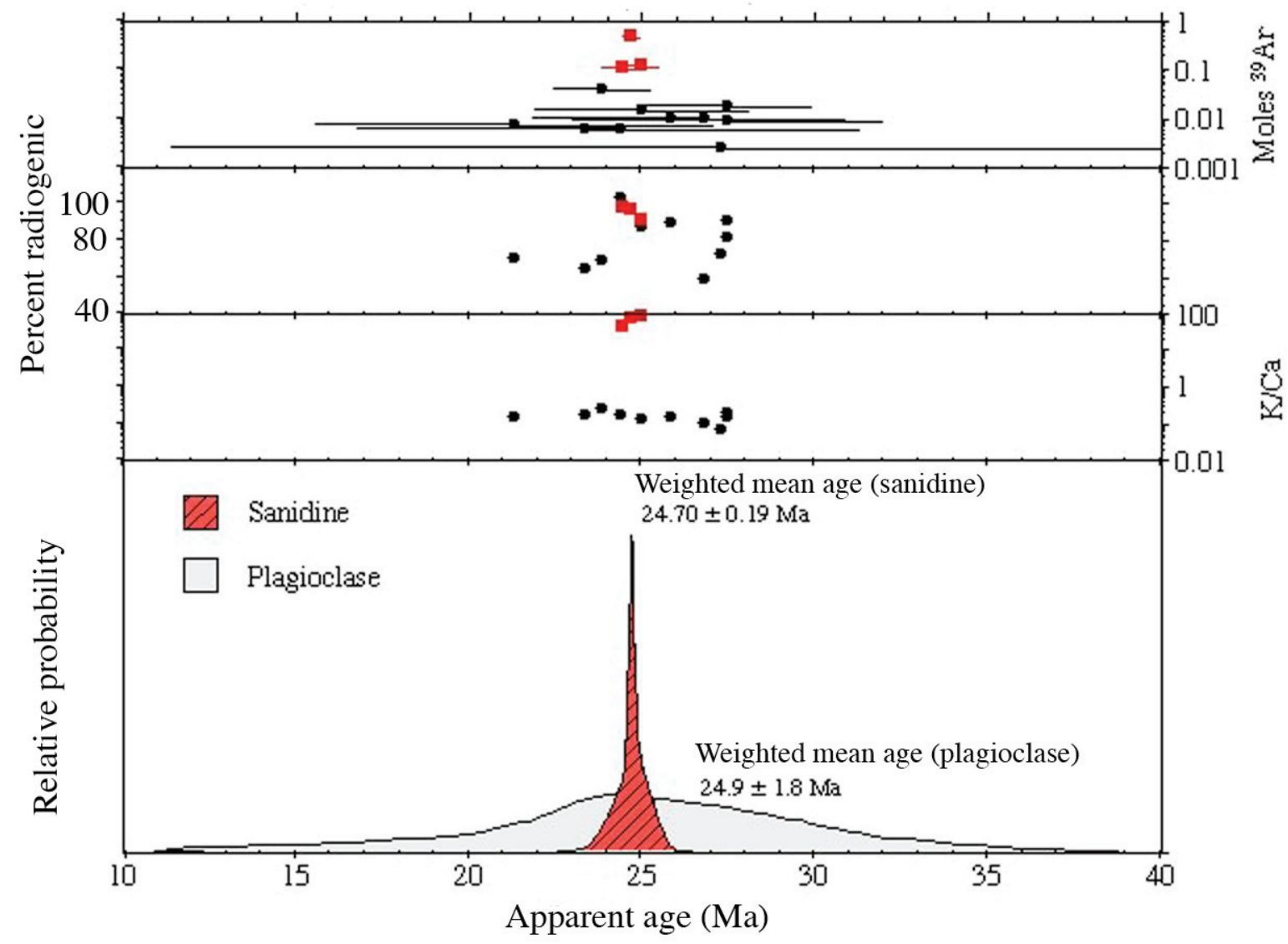

Figure 15. Age probability distribution diagram or ideogram for the 615BAT99 feldspar separate (formation of Tinaja Peak). The weighted mean of the three single-crystal sanidine ages $(24.70 \pm 0.19 \mathrm{Ma})$ is the preferred age for this sample. The sanidine crystals yield a population interpreted to record the age of eruption of the ash-fall tuff. Although the plagioclase crystals $(\mathrm{K} / \mathrm{Ca}<10)$ yield a weighted mean age $(24.9 \pm 1.8 \mathrm{Ma})$ indistinguishable from that of the sanidine crystals, the higher uncertainty of the individual plagioclase ages warrants excluding these data from the weighted mean age of the sample. Error bars are two sigma. 


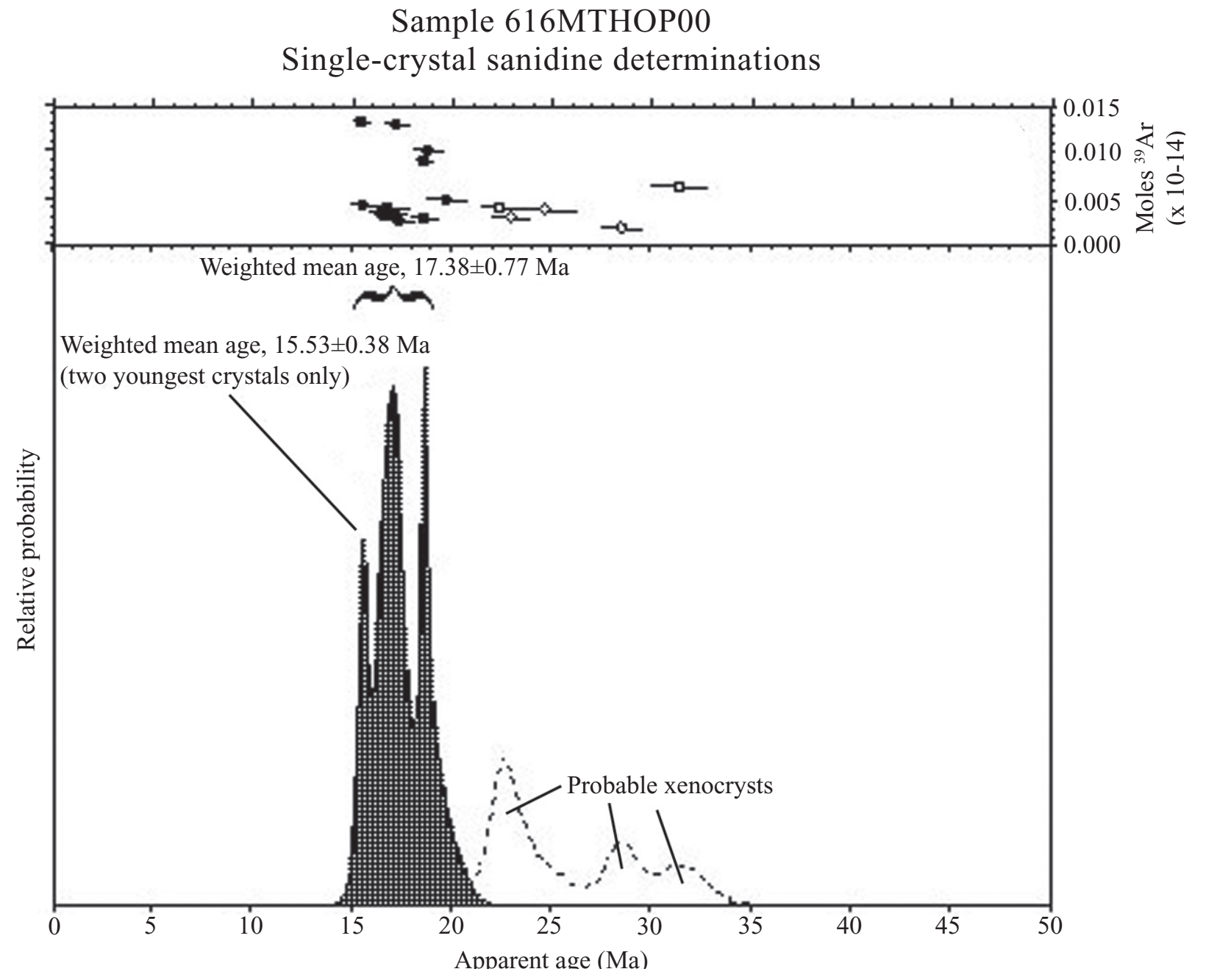

Figure 16. Age probability distribution diagram or ideogram for the sanidine separate from 616MTHOP00 (Nogales Formation). The analyzed crystals were very small (60-80 mesh), which resulted in signal sizes barely above the normal blank level. When these data were reduced in the usual way, we noted that eight of the eighteen analyzed crystals had radiogenic yields over 100 percent. Negative ${ }^{36} \mathrm{Ar}$ signals (caused by overestimation of the blank) resulted in the ${ }^{40} \mathrm{Ar} /{ }^{39} \mathrm{Ar}$ ratio being overcorrected for atmospheric argon. The precision of these analyses was improved by making the assumption that the crystals are all 100 percent radiogenic and using the measured ${ }^{40} \mathrm{Ar} /{ }^{39} \mathrm{Ar}$ ratio rather than the corrected one. When calculated in this way, the crystals reveal a spread in ages from $15.51 \pm 0.42 \mathrm{Ma}$ to $118 \pm 20 \mathrm{Ma}$. After eliminating the oldest six crystals (indicated by the dashed curve) as probable xenocrysts, the remaining crystals yield a weighted mean age of $17.38 \pm 0.77 \mathrm{Ma}$. The age spread even in the data not corrected for atmospheric argon is much greater than expected for a normal population, as evidenced by an unacceptable mean sum weighted deviation (MSWD) of 18 (Mahon, 1996; see discussion of MSWD in table 2 footnote). If the spread to older ages is due not only to analytical problems because of the small signal size, but to xenocrystic material, a weighted mean of the two youngest crystals $(15.53 \pm 0.38 \mathrm{Ma})$ would be assigned as the best age of this sample. Error bars are two sigma.

Figure 17. Age spectra of biotite separates from a silicic tuff penetrated in the Exxon State (32)-1 well (middle Tertiary volcanic and sedimentary rocks). The biotite was collected from 2,584-2,600 $\mathrm{m}(8,478-8,530 \mathrm{ft})$ and $2,600-2,609 \mathrm{~m}(8,530-8,560 \mathrm{ft})$. The two contiguous intervals were sampled separately because there is a slight color change in the tuff at $2,600 \mathrm{~m}(8,530 \mathrm{ft})$. Both samples yield age spectra with high $\mathrm{K} / \mathrm{Ca}$ ratios, increasing radiogenic yields, and young apparent ages in the first $15-40$ percent of the ${ }^{39} \mathrm{Ar}$ released during step heating (steps labelled by letters and temperature in ${ }^{\circ} \mathrm{C}$ ). Integrated ages include the data of the initial heating steps. Weighted mean ages are calculated from the remaining parts of the age spectra. Biotite from 2,584-2,600 m (8,478-8,530 ft) yields a weighted mean age of $26.91 \pm 0.18 \mathrm{Ma}$ that includes 94 percent of the ${ }^{39} \mathrm{Ar}$ released and has an acceptable MSWD (Mahon, 1996). The biotite from the deeper interval (2,600-2,609 $\mathrm{m}$ $(8,530-8,560 \mathrm{ft}))$ yields a weighted mean age of 26.80 $\pm 0.44 \mathrm{Ma}$ that includes 61 percent of the ${ }^{39} \mathrm{Ar}$ released and also has an acceptable MSWD. The dates from both samples are analytically indistinguishable, indicating the tuff in both intervals is the same. The disturbed early parts of both spectra are probably due to alteration of the biotite. The age spectrum of the upper interval suggests less alteration than the more disturbed age spectrum of the lower interval. The weighted mean of the sample from the upper interval also yields a more precise weighted mean age $(26.91+0.18 \mathrm{Ma})$ and is, therefore, the preferred age for the eruption of the tuff. 

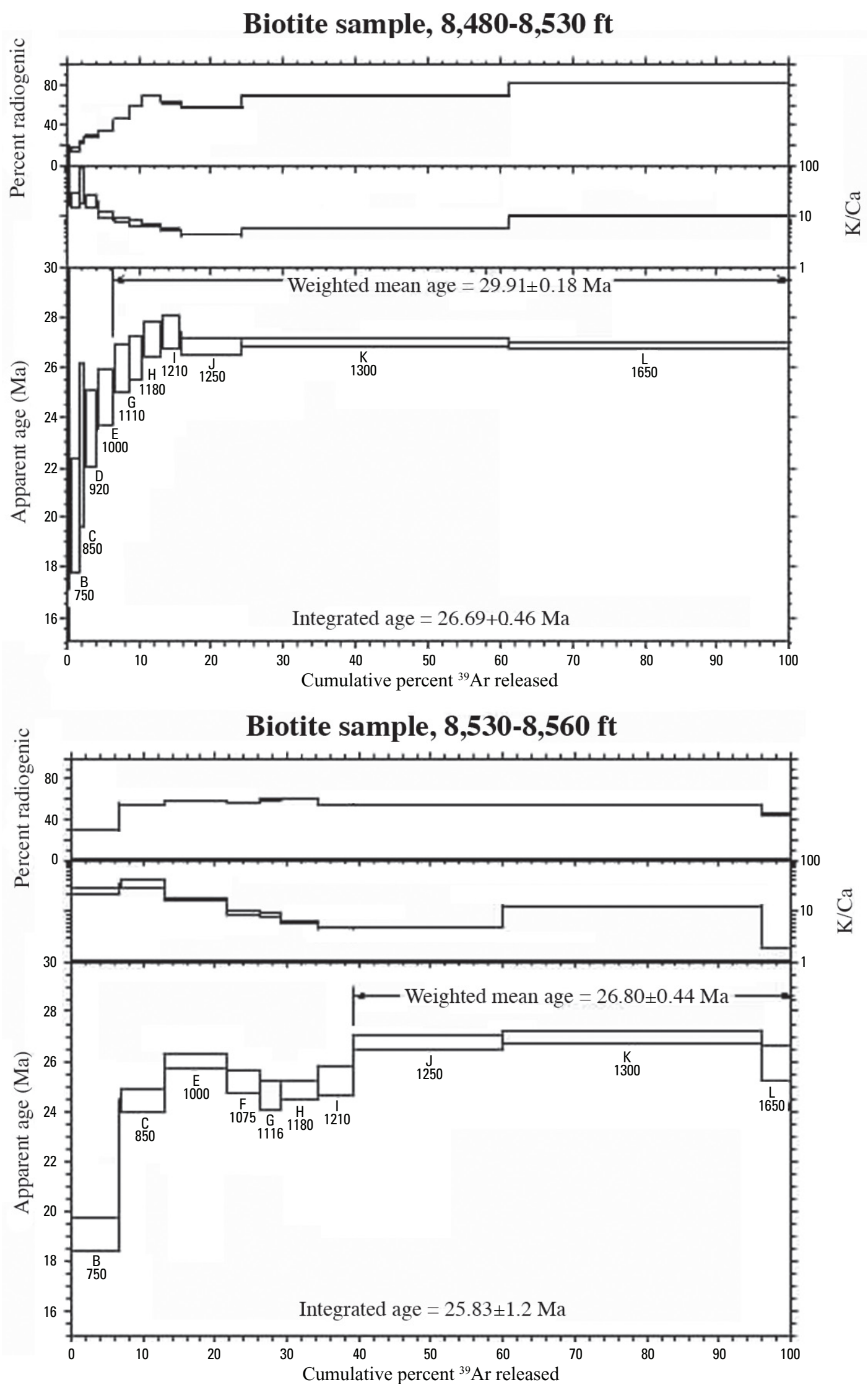